Historic, Archive Document

Do not assume content reflects current scientific knowledge, policies, or practices. 




\section{Annual Catalog and Price List}

\section{Economic and Ornamental}

\section{Fruit Trees and Plants}

Panama Rhubarb, Berries, Vegetable and Flower Seeds

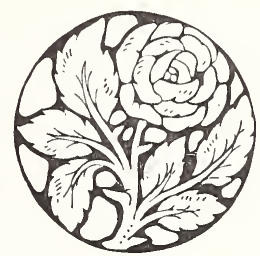

WAGNER NURSERIES

1350 NORTH FOOTHILL BOULEVARD PASADENA, CAL. 


\section{PLEASE OBSERVE WHEN ORDERING}

Use order sheet, fill out carefully, and much delay and trouble will be avoided. We fill orders as soon as received, if the stock is ready. Customers who wish their order or any part of it booked for shipping at a later date should so state.

COMPLAINTS. If any error has been made in your order claim must be made within 5 days after receipt of the goods, or same will not be entertained.

SUBSTITUTION. Please state whether substitution will be permitted otherwise we will feel at liberty in filling the order to use other varieties as near similar as possible. It very often happens on orders of assorted varieties, for a home orchard, that it is necessary to make substitutions. On orders for commercial planting substitutions are never made without first obtaining the consent of the purchaser.

TERMS. Cash with order. Orders sent C. O. D., will be filled, provided onethird of the amount is sent with the order. At our prices we cannot afford to do a credit business.

REFERENCES. As to our reliability we refer to our 30 years specializing in rhubarb, berries, and small fruits. Our thousands of pleased customers; Dunn and Bradstreet's Commercial Rating Agencies; any bank in Pasadena.

TRUE TO NAME. W'hile we use every precaution to have all plants, bushes, etc., true to name we will not be responsible for any sum greater than the cost of the stock, should any prove otherwise than as represented. And in no case, where, for propagating purposes, or lor filling orders, we secure seeds, plants, scions, cuttings or buds from others, do we assume responsibility or give any guarantee whatever.

ALWAYS GIVE FULL ADDRESS. This is important; write your name plainly, your postoffice, county and state.

SHIPPING INSTRUCTIONS. Give your nearest express office and railway station, stage route or transportation company, and how you wish us to ship. Where possible we advise sending stock by express. If you wish stock by parcel post add $10 \%$ additional to your remittance or 10 cents for every dollar's worth of stoek or fraction of a dollar, and we prepay charges except when canned, balled or potted. which must be sent collect.

IMPORTANT. There are a great many varieties of fruits advertised in most catalogs. It is very confusing to fruit growers inasmuch as they are generally described as the best, and some are sure to disappoint the purchaser. We call your attention to the fact that we list only varieties that will give entire satisfaction to the planter. We have grown and tested hundreds of varieties of fruits, and have kept discarding the worthless varieties until our catalog is used to list the varieties of merit, and varieties that will give the planter satisfactory returns.

We wish to thank our old customers for their pationage during the past years and it is our sincere desire to merit it in the tuture and trust that we will have the pleasure of serving you this coming season. This catalog is printed for your benefit and we ask you to read and study it carefully. We will be glad to furnish you with any additional information if you wish it at any time. 


\section{WINTER RHUBARB}

Winter producing rhubarb was originated and introduced by Luther Burbank some twenty-five years ago and was called Burbank Crimson Winter, the bulk of his stock of plants being sold to Mr. J. B. Wagner some two or three years after they were introduced and were propagated by him for several years. By continual crossing and hybridizing, new varieties were secured out of which one was selected that was called Wagner's Giant Crimson, which after several years of testing and propagating was placed on the market and for a number of years was the leading commercial variety of winter rhubarb.

The next step forward in the production of an improved winter variety was the introduction of the Panama variety some four years later, which is fast replacing any and all sorts of rhubarb that are grown for commercial purposes.

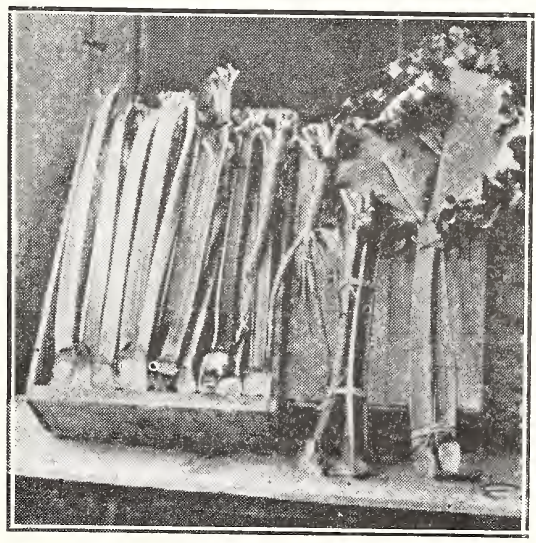

PANAMA RHUBARB

Anyone planting rhubarb in a commercial way makes a very serious mistake in planting anything but the winter producing varieties as the summer varieties will only bear during a short period in the early spring and summer, while the winter bearing varieties will produce continuously throughout the entire year.

Winter rhubarb is unquestionably profitable if one has the proper conditions for its growth. We do not recommend planting winter rhubarb with the expecting of large winter returns where severe frosts are experienced. The lighter soils are preferred as they are usually the warmer soils, but rhubarb can be grown on quite heavy soil if continuous cultivation is practiced. The richer the soil, the better for rhubarb culture as it is an unknown incident where too much fertilizer has been given.

The rhubarb plants may be set at any season of the year with the exception of the month from the fifteenth of December to the fifteenth of January, which is usually the coldest season of the year and during which time if planted, and the ground for any reason is not well drained, the plants are very apt to decay.

Rhubarb planted prior to the first of September should produce a marketable crop the following February and we often recommend planting any time the ground is ready as the sooner the plants are in, the sooner one will obtain marketable crops, and if this crop should come during a period of low prices, which is usually between June and September, there is absolutely no loss as the plants will be just that much larger and stronger for the spring crop. 


\section{WINTER RHUBARB GROWING}

Winter Rhubarb. Starts to grow vigorously by October and produces stalks continually until after common varieties make their first appearance some six months later. If kept moist will produce stalks abundantly at all seasons; it is, in fact, absolutely perpetual. For growing in California and shipping East, it has proven to be more profitable than anything the soil produces. Never plant seed or seedlings for commercial use if true subdivisions are obtainable. It deteriorates rapidly when far removed by use of seedlings from original.

\section{THE GREATEST MONEY CROP IN CALIFORNIA}

Plant 2 by 5 feet. Long experience indicates this is best distance to plant; $2 \times 5$ feet requires 4.335 per acre. By planting close in row it causes stems to grow longer and more tender and in no way is injurious while more and redder stenis are produced from same area. Also the dense foliage protects stems from frost during winter and shades the ground during hot weather. Where it is desired to cultivate the ground both ways, plant $3 \times 4$ feet. This requires 3,660 plants to the acre.

\section{PREPARATION OF THE GROUND AND FERTILIZING}

If manure is to be applied before planting, scatter it broadcast, and work it into the ground well before planting. Never fill a furrow with manure and then plant the roots in the furrow as it is apt to rot the plant. If manure is to be applied after planting do not apply until the plant starts to grow by beginning to sprout, then drill the manure in the furrows about 4 inches from the plants and cover. Do not be afraid to fertilize as it is improbable that you will give it too much. Nitrate of Soda is the best commercial fertilizer for rhubarb but should be applied only about two months before crops are desired and at the rate of 300 pounds per acre, applied in furrows and covered. it is necessary that the ground be wet to make it available to the plants. PLANTING-Ground should be in well tilled condition; draw furrows with hand plow where plants are to be set and irrigate the furrows: as soon as the ground is dry enough to work on (12 to 18 hours) set the plants in the bottom of the furrow at a depth that will leave the top of the plant about $1 / 2$ inch below the surface of the ground when the furrows are filled in. Irrigate the furrow immediately after planting and as soon as dry enough to work the furrows should be filled in covering the plants over to about the depth of $1 / 2$ inch, rake the ground so it will be pulverized. Irrigate and cultivate every 10 days for the first two months then as often as you deem necessary to keep the ground moist near the crown.

Contrary to the general opinion a large rhubarb sub-division or seedling is not the best to plant, as the root that is planted does not grow but merely keeps the crown alive until the eyes start to grow and send out new roots, and the old root that was planted decavs and the plant lives and grows from the roots near the surface of the ground. This is the reason and necessity to keep the ground moist near the crown of the plant for the first two months so as to keep the new fiber roots from becoming dry which of course will die if not kept moist. Be sure and do not have the crown more than $1 \%$ inch below the surface of the soil as if they are they will only make a weak growth and in most cases will die after one or two attempts of growing. Winter Rhubarb may be planted successfully any time of the year, but for commercial plantings we recommend from February to October.

We feel confident that any one planting Rhubarb on a commercial basis will not be disappointed in their venture. We have given above, information that will enable you to judge for yourself as to whether or not you can succeed in making money growing rhubarb for profits. We are ready at all times and are willing to give you information on the growing and culture of rhubarb in a commercial way, as we have been in the business twenty years growing and experimenting with rhubarb, and you are assured of our sincere desire to advise with you.

Mr. J. B. Wagner originated all the varieties of Winter Rhubarb grown commercially today, and in his 20 years experimenting work has tested every known sort from every part of the world where rhubarb is grown. In all about 250 varieties have been used in hvbridizing and crossings with results as set forth herein, this was accomplished largely through the efforts of our U. S. Agricultural Department at Washington, D. C., who, as well as our State Agricultural and Horticultural Organizations generally recognize Mr. J. B. Wagner as the best authority on rhubarb in the world today.

We have endeavored in above treatise to answer all of the leading questions commonly asked by intending purchasers. In case there is any further information regarding soil or other conditions desired on the subject, write us and we will be pleased to answer any direct queries not herein covered. We carry one of the largest assortments of berry and small fruit plants to be found in the State. Kindly give same careful attention and submit a list of your wants. Our rhubarb, berry and small fruit experimental grounds are open to the public-you are invited to visit them at any time. 


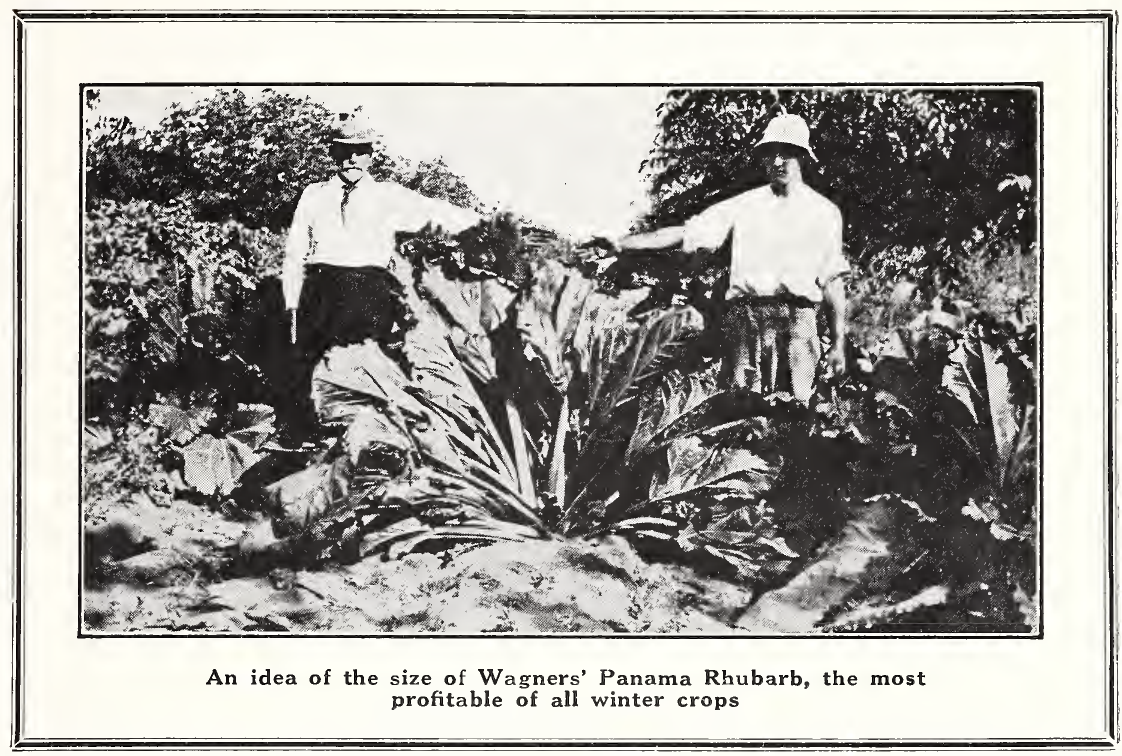

\section{WAGNER'S PANAMA RHUBARB}

\section{The Greatest of All Winter Crops}

Wagner's Panama Rhubarb. We offer herewith the best rhubarb it is possible to grow. We have experimented with rhubarb for twenty-five years and are responsible for every named variety of Winter Rhubarb that is now offered to the public, of which Wagner's Panama is supreme. It produces as high as twenty tons per acre and very strongly resembles the strawberry rhubarb, but, unlike the strawberry variety, it produces over the entire year and is at its best during February and March when prices of $\$ 2.00$ per box of 30 pounds is obtainable.

It should be planted from subdivisions, the same as all other winter varieties; seed lings do not reproduce. The plants should be set any time from January to November and planted in well prepared ground. Set the crowns of the plants not to exceed onehalf inch under the surface of the ground Irrigate when planted and keep well cultivated at all times. Price, 25c each; $\$ 2.00$ per dozen; $\$ 15.00$ per $100 ; \$ 100.00$ per thousand.

Wagner's Giant Amber Winter. A cross of Burbank's Crimson Winter and the Golden Syrup, one of the best amber colored winter rhubarbs. Extremely hardy variety. Recommended for sections where climate is questionable as it stands exces sive heat and colds better than any known sort. Excellent for cooking. Each, 20c; dozen, $\$ 1.50$; hundred, $\$ 8.00$; thousand, $\$ 60.00$.

Wagner's Giant Crimson Winter. Noted for length of stem which often weighs $11 / 4$ pounds. We have picked at one time from a single plant 60 full grown stems that weighed 30 pounds. This variety does not run much to seed; to get the plants the crowns have to be subdivided. The stems are as tender as any known plant and have good color; does not have to be peeled for cooking. The best growing season is from October until June. Some dealers divide old
Giant Seedlings and sell them for true subdivisions. It will pay you to demand the genuine. Each, 20c; dozen, $\$ 1.50$; hundred, $\$ 8.00$; thousand, $\$ 60.00$.

Wagner's Giant Seedling. Not recommended for general commercial planting. Being grown from seed of the famous giants it yields up to 20 tons per acre. E.ach, 15c; dozen, $\$ 1.00$; hundred, $\$ 6.00$; thousand, $\$ 40.00$.

Wagner Giant Cherry. Produces a good size stock of bright red color and is a good winter producer excepting it does not stand quite as much cold as the Panama, but is very much in demand due to its bright color. Each, 25c; dozen, $\$ 2.00$; hundred. $\$ 15.00$; thousand. $\$ 100.00$.

\section{Summer Varieties}

Improved Strawberry. One of the best adapted to the North Coast sections and extensively grown in rhubarb sections a round San Lorenzo. The stems are not of a red color as one would think but are green; if bleached are of a pink color. Cropping season, March to July. Each, 15c; dozen, $\$ 1.25$; hundred, $\$ 4.00$.

Wagner's Improved Linnaeus. An improvement over the old Myatt's Lineaus. Heavier producer, stalks heavier and thicker and comes 10 days earlier. You can make no mistake in planting this variety for early Spring and Summer crops, as it is a heavy yielder and the best summer variety grown by us. Each, 20c; dozen, $\$ 1.50$.

Riverside Giant. An excellent variety. Stalks crisp and tender. A very good com mercial rhubarb. Excellent for cooking; when cooked the skin disappears. Cuttings of this variety are made in the month of March and continue through the summer months. Lower part of stalk is a bright red color and of largest size. Each, 20c; dozen, $\$ 2.00$. 


\section{THE BERRY FRUITS}

\section{Blackberries}

Advance Blackberry. The earliest of all blacks and a good berry, but sometimes a shy bearer. A very good keeper and grown much for early shipment. Each, 20c; dozen, $\$ 2.00$; hundred, \$10.00.

Cory's Thornless Mammoth. The earliest and largest blackberry grown. The foliage and habit of growth are identical with the Mammoth. Should be trelised for best results. The fruit is of immense size, long and in every respect resembles the Mammoth, for which it is often mistaken, but the fruit averages larger and has a better flavor, having a distinct Black Cap Raspberry flavor. Hardy anywhere, very small seeds; excellent for table and canning, jelly or jam. A flavor all its own and simply superb; served in many ways. A good shipper and market berry. Each, 10c; dozen, $\$ 1.25$; hundred, $\$ 8.00$; thousand, $\$ 50.00$. Plant $6 \times 7$.

Burbank Thornless. The latest ripening and sweetest of all blackberries; comes at a time when there is no other. Each, 15c; dozen, $\$ 1.25$; hundred, $\$ 8.00$. Plant $6 \times 7$.

Crandall Blackberry. Early, strong upright grower; no trellising needed. Heavy producer; fruit medium size, roundish, jet black, fine flavor. Each, I0c; dozen, \$1.00; hundred, $\$ 5.00$. Plant $3 \times 7$.

Himalaya Blackberry. Late, long season cropper; begins to ripen with the last of the others. Does not die back after fruiting, but continues to grow for many years like a grape vine. Should be trellised. Berry medium, round; fine flavor, jet black. Good for canneries. Fruits right up to frost. Plant $6 \times 10$ feet. Each, 10c; dozen, \$1.0v; hursdrcd. $\$ 6.00$.

Mammoth Blackberry. Early, begins to ripen right after Cory. Fruit of the largest size, very long and black. Should be trellised. Plant $5 \times 7$ feet. Each, 10c; dozen, $\$ 1.00$; hundred, $\$ 7.00$.

Lawton Blackberry. Medium early, very similar to the Crandall in habit though canes grow stronger and not so weeping. A good producer with fine fruit. Plant $3 \times 6$ feet. Each, 10c; dozen, \$1.00; hundred, $\$ 6.00$.

Iceberg. (White Blackberry.) An amber colored blackberry, medium size, good but different flavor from other blackberries. The habit of vine is similar to the Lawton. Very prolific. Plant $4 \times 6$ feet. Each, 15c; dozen, $\$ 1.50$.

\section{Dewberries or Trailing Blackberries}

Wagner Rose Dewberry. The earliest Dewberry; in fact, the first of any of the blackberries to ripen. An excellent keeper and shipper, and the best money making berry. The crop is all picked before any other berry is ready to pick. Plant $3 \times 7$ feet. Each, 25c; dozen, \$2.00; hundred, $\$ 10.00$.

Wagner Thornless Dewberry. Similar to Gardena, but earlier, ripens between Rose and Gardena; absolutely thornless, unsurpassed in flavor and productiveness and bound to become the leader of all dewberries. Now being introduced by us for the first time. $75 \mathrm{c}$ each.
Gardena Dewberry. Extra early, begins ripening ahead of the Mammoth. It is the heaviest yielder of any of the family. Fine flavor; good for table use. Plant $3 \times 5$ feet. Each, $10 \mathrm{c}$; dozen, $\$ 1.00$; hundred, $\$ 5.00$.

Lucretia Dewberry. The only late Dewberry worthy of planting. Comes in after the Gardena. Plant $3 \times 5$ feet. Each, 10c; dozen, $\$ 1.00$; hundred, $\$ 5.00$.

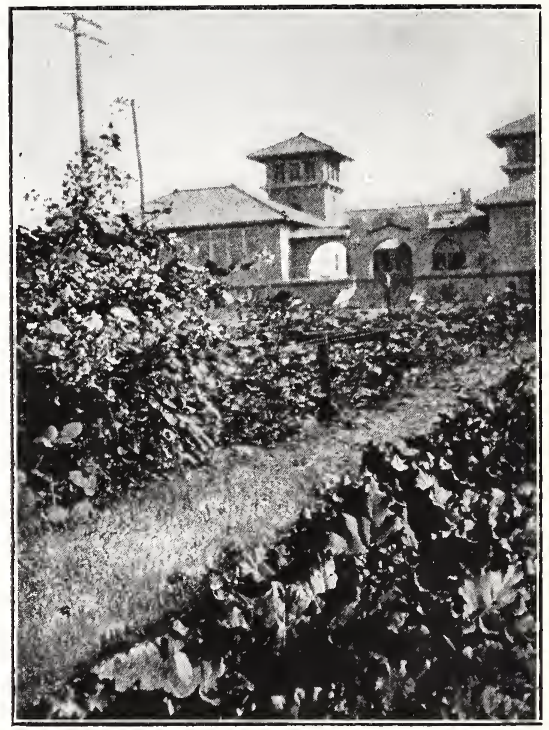

HIMALAYA BLACKBERRY (1 Year)

\section{Loganberries}

Loganberry. A cross between the Raspberry and the Blackberry. Quite tart unless very ripe. Unexcelled for table use, jam, jell, canning or drying. Trailing in habit like the Mammoth and should be planted and treated in the same manner. Begins ripening shortly after the Mammoth. Plant $5 \times 6$ feet. Tips each, 10c; dozen, 75c; hundred, $\$ 6.00$.

\section{Phenominal Berry}

Phenominal Berry. Similar to the Logan except a trifle larger and has less acid and fewer seeds. Plant $5 \times 6$ feet. Each, 15c; dozen, $\$ 1.50$; hundred, $\$ 10.00 ;$ thousand, $\$ 75.00$.

\section{Red Raspberries}

California Surprise. The earliest and most productive of any Raspberry. Where climatic conditions will permit, this sort can be picked every month of the year. Hardy in any section where it does not get below zero. Fruit medium size, good color and flavor unsurpassed. We recommend it in preferance to any other. Each, 10c; dozen, $75 \mathrm{c}$; hundred, $\$ 5.00$. 


\section{CUTHBERT RASPBERRY}

Cuthbert. Red, medium to late. Has been the standard for over fifty years. Does extra well in most sections of the Pacific States. Fruit large, firm and fine quality. Each, 10c; dozen, 75c; hundred, $\$ 5.00$.

Superlative. Everbearing. Medium early, large red fruit. Vigorous grower. Preferred to most others in the Northern Coast sections where excessive rains occur. Each, 10c; dozen, $\$ 1.00$; hundred, $\$ 7.50$.

St. Regis. Recent introduction; fruit a bright crimson; a long season cropper; early to quite late. Firm flesh, a good shipper. Hardy anywhere. Each, 10c; dozen, 75c; hundred, $\$ 5.00$.

Ranere. An excellent everbearing red raspberry. A good variety. Berries can be picked from early in season until the early frosts. Each, 10c; dozen, $\$ 1.00$; hundred, $\$ 7.00$.

Wagner's Everbearing Golden Queen. It is almost identical with Cuthbert except color, it being a beautiful yellow. Heavy producer, first class quality. It is one of the finest berries grown for flavor and bearing qualities. We have never grown or tasted a berry of better flavor. Try a few. Each, $15 \mathrm{c}$; dozen, $\$ 1.50$.

La France. Great red everbearing. New, thoroughly tried, very promising. Very large bushes, berries slightly larger than ordinary. Like St. Regis bears all season with heavy fall crop. Each, 15c; dozen, $\$ 1.50$.

\section{Black Raspberries}

Each, 10c; Dozen, \$1.00; Hundred, \$6.00; Thousand, $\$ 40.00$

Columbian Purple. One of the sweetest and best raspberries for table use or cooking.

Plum Farmer. Berry large and attractive, an excellent market berry.

King of the Cliff. A good variety of Black Cap for home and commercial use. Is fast beconing a popular berry in this section.

Cumberland. A vigorous growing variety, very productive. Jet black fruit; somewhat longer in season than the Plum Farmer.

Munger. One of the leading sorts.

\section{Strawberries}

Each, 5c; Dozen, 25c; Hundred, \$1.50; Thousand, $\$ 8.50$, Unless Otherwise Noted

Banner Strawberry. Resembles in almost every respect the New Oregon. While there may be some slight variation in these two varieties as grown in certain sections our experience here has been that they are practically one and the same berry.

New Oregon Strawberry. Destined to be the coming commercial strawberry. It produces a vigorous upright growth that bears extremely early and abundantly. Practically immune to any insects, pests and diseases: bears from two to three years longer than any other known variety. Price, 10c each; $50 \mathrm{c}$ per dozen; $\$ 1.50$ per $100 ; \$ 10.00$ per thousand.

Brandywine. Perfect, large roundish conical, bright red, firm and rich flavor; medium to late. Its size and color attracts everyone.

Carolina. A new variety far superior to most. It is earlier, bearing continuously throughout the summer and fall months. Plants will bear a full crop of berries eight to twelve weeks after planting. We advise planting this variety where quick returns are wanted for home or commercial use. Dozen, 30c; hundred, $\$ 1.50$; thousand, $\$ 9.00$.
Klondike. Perfect; very vigorous grower, hardy anywhere. Fruit large, uniform, blood-red, juicy and of delicious flavor. Stands drought well. A favorite with market growers and the canneries, both East and West.

Progressive Everbearing. The most vigorous growing plant of all the Everbearing Strawberries. Plant and fruit closely resemble Dunlap. The berries are produced in great abundance and are of extra fine flavor, the latter depending upon conditions of soil and climate. lt is a good variety for home and commercial use. Dozen, 50c; hundred, $\$ 3.00$; thousand, $\$ 15.00$.

Wagner Everbearing. A new everbearing introduced by us. The largest fruit of any everbearing and of finest quality; bears until frost, and a heavy crop at all times; one of the best. Dozen, $35 \mathrm{c}$; hundred, $\$ 2.00$; thousand, $\$ 12.00$.

\section{Gooseberries}

Each, 25c; Dozen, \$2.00; Hundred, \$10.00

Oregon Champion. Large brownish red. Strong grower, heavy bearer. Plant $3 \times 5$ feet.

Downing. Yellowish green, extra large, strong grower, prolific bearer. Plant $3 \times 5$ feet.

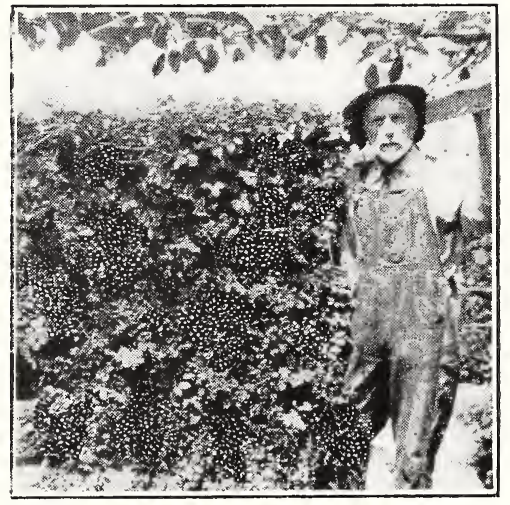

THORNLESS BLACKBERRY

Wagner's Improved Houghton. Enormously productive. Vigorous, slender, spreading growth, the fruit hanging thick on the under side of the branches. Fruit a good size, smooth, pale red, or purple when ripe. It is the only variety we can recommend to withstand our hot interior valley climate. The most profitable of all gooseberries.

\section{Currants}

Each, 25c; Dozen, \$2.00; Hundred, $\$ 10.00$

Perfection. Recent introduction. Everything good that can be said of a red currant seems to apply to the Perfection. Plant $3 \times 4$ feet.

Fay's Prolific Red. One of the old standards which is hard to beat. Produces immense crops of fine fruit.

Cherry. Red. Large fruit. One of the best.

Wilder. Red. Vigorous, upright growing bush, hardy and productive. Fruit large, grows in fine large clusters; excellent quality. We consider this the best of all currants as a cropper and money maker. 


\section{TABLE AND RAISIN GRAPES}

\section{Table and Raisin Grapes}

Each, 15c; Dozen, \$1.25; Hundred, \$6.00, Unless Otherwise Noted

Malaga. Very large bunches, of ten weighing 10 pounds; fruits very large oval; yellowish green. A good shipping variety, commanding a high price in the eastern markets.

Muscat. Oblong, light transparent yellow with heavy bloom that gives an attractive finish when dried. The most important raisin grape in California.

Thompson Seedless. Medium size, yellow berries, large bunches. Entirely seedless. Strong grower, heavy producer. The finest seedless raisin grape and fine for arbors.

Rose of Peru. Very large, brownish black; flesh tender, juicy, rich and sprightly. The vine is a strong grower and does well on a trellis. September.

Emperor. A large, late purple, oval berry in large loose bunches. A vigorous grower and good shipping variety.

Black Hamburg. A fine tender table grape producing large compact bunches. A great favorite for table and market.

Tokay. Flaming Tokay. Large, red berries in large bunches, heavy bloom.

Black Hamburg. A fine tender table grape producing large compact bunches.

Black Morocco. Berries very large oval, purplish black when ripe; flesh firm, sweet and crisp. This is an excellent late shipping grape.

Cornichon. Long, loose bunches; oval, tapering at both ends; firm and of fine flavor; ripens late and is a splendid sort for shipping.

\section{Juice Grapes}

Also Fine for Table. Each 20c; Dozen, $\$ 1.50$; Hundred, $\$ 8.00$

Mission. This is the grape introduced in the early mission days and is widely distributed, thriving in most every section of California. Medium size, dark blackish purple. Very sweet and delicious.

Zinfandel. Dark purple grape in large compact bunches. Has heavy bloom. Thrives under any average condition. This was one of the leading claret grapes in California.

Mataro. Is somewhat similar to the Mission Grape and is very popular; is also one of the finest and best shipping grapes known.

Blue Elb and Gernische. Good quality wine grape; very juicy. Medium size, rea sonably good shipper.

\section{Eastern Grapes}

Each, 25c; Dozen, \$2.00; Hundred, $\$ 15.00$

Concord. The best known and popular of all grapes. Best for table, wine and market; succeeds over a great extent of country.

Niagara. This white grape is justly regarded as one of the very best known; very fine quality for a table grape; very prolific, hardy and of fine flavor.

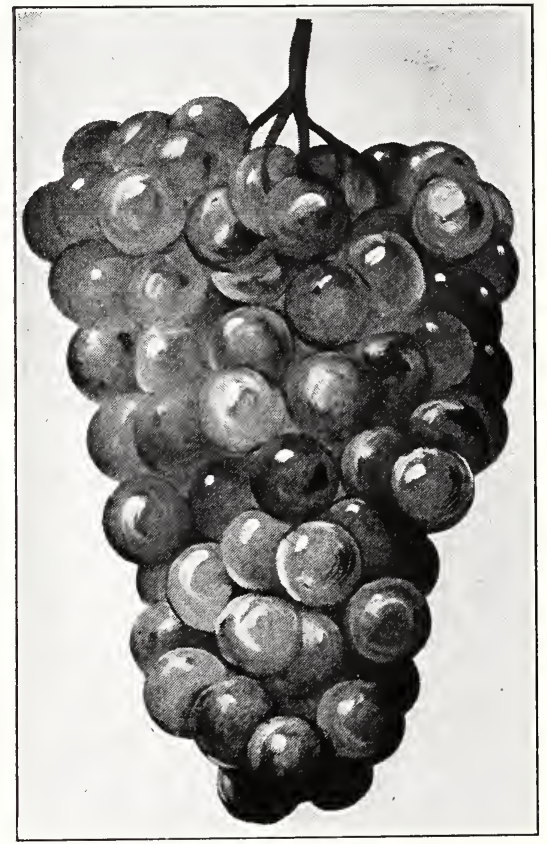

\section{CONCORD GRAPE}

Worden. A seedling from the Concord which it greatly resembles in color and appearance. lt is, however, several days earlier; much more delicious and melting and has a flavor that is equaled by no other grape grown. Berries and clusters are very large and compact; vine is fully as hardy as the Concord and more productive. It is a sure bearer.

Isabclla. Berries large, round, dark purple; sweet and rich. Succeeds well in California.

Moore Early. Similar to Concord in appearance and quality, but two weeks earlier. Vine healthy, hardy and succeeds wherever Concord grows.

Campbell Early. Earliest of American grapes to ripen. Large, black, sweet berries in small or medium bunches. 


\section{CITRUS AND TROPICAL FRUITS}

\section{Plant Guavas}

It is the last fruit we have in the fall after all other fruits are gone, unsurpassed for eating raw, cooked, or in jell or jam, makes a beautiful evergreen hedge, set 2 to 3 feet apart. It fruits heavy and young.

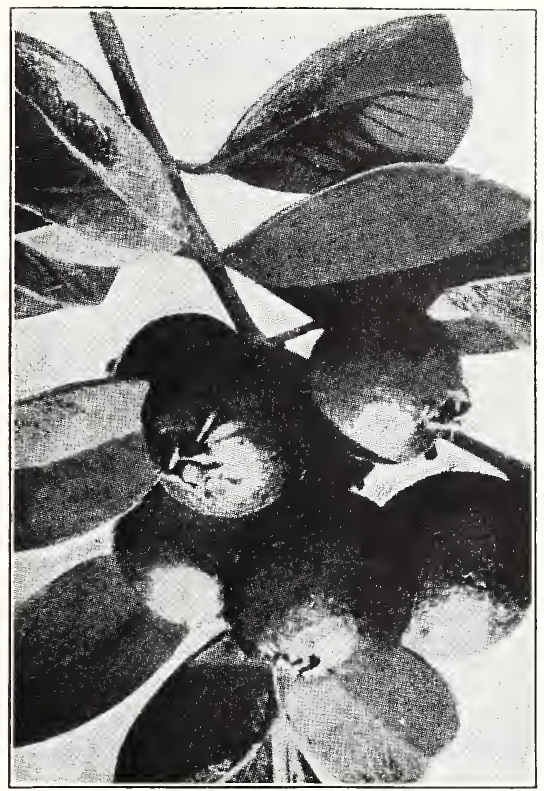

\section{STRAWBERRY GUAVA}

Strawberry Guava. (Red.) Round; deep claret color, strawberry flavor. A low growing bush. Never trim or try to train its habit of growth. You cannot make a tree of it and get good fruit. 18"-24", $50 \mathrm{c}$ each. Small in pots, $25 \mathrm{c}$ each, $\$ 2.00$ per dozen.

Strawberry Guava. (Yellow.) Same in every respect as the red, except the fruit averages much larger and is a beautiful golden yellow; not so acid as the red straw. berry guava; to our mind it is much finer fruit in every respect. 12"-18", $25 \mathrm{c}$ each, $\$ 2.00$ per dozen. 2.3 feet, $50 \mathrm{c}$.

\section{Feijoa}

Feijoa. (Pineapple Guava.) Absolutely one of the finest fruits on earth. Really indescribable. Eat a ripe one and you will eat more if you can buy or raise them. The plant is quite hardy and has stood zero weather out doors. It ripens late in the fall the same as the others. Greenish yellow when ripe and frequently as large as a hen egg. The flavor seems to be a mingling of the pineapple, raspberry and banana. In eating it, one is reminded of the old easter May apple or May pop. It is a fine ornamental as well, its bright glossy green leaves remaining on the plant all the year. The blossom is very pretty showing pure white beneath and purple above. Well worthy a place for flower alone; makes pretty hedge. Plant a few and have them for show and value. 12"-18", 25c each, $\$ 2.00$ per dozen, $\$ 10.00$ per hundred. $18^{\prime \prime}$. 24 ", $35 \mathrm{c}$ each. $3-4$ feet in cans, $75 \mathrm{c}$ each. 4 feet and up in cans, $\$ 1.00$. A few budded trees in cans, $\$ 1.50$ each.

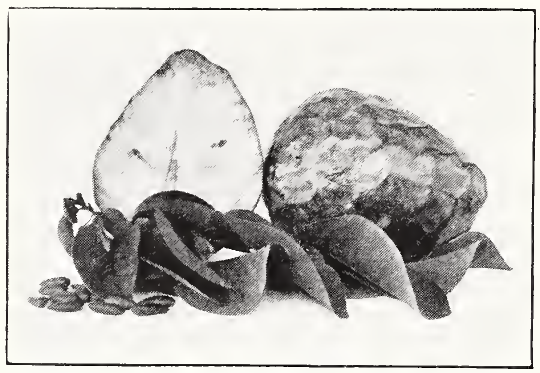

WAGNER CHERIMOYA

\section{Cherimoya}

Cherimoya. (Custard Apple.) Stands about as much cold as the orange and makes a large spreading drooping tree. Never sheds its foliage unless frozen. Evergreen in some sections. The fruit often weighs $11 / 2$ pounds. The flesh is more the consistency of ice cream and has a delicious indescribable flavor all its own. 18 to 24 inches in pots, $75 \mathrm{c}$; larger size, $\$ 1.50$ to $\$ 2.00$.

\section{Sapote}

Sapote. (Casimiroa Edulis.) A large fast growing tree; five-fingered, sharp-pointed foliage. Quite tender for frost, but quickly recovers. Fruit yellowish or gray green; yellow or white pulp with several good sized seeds. Flavor difficult to describe; has a suggestion of the Eastern pawpaw. Tree remarkably drought resistant. Small, $\$ 1.00$.

\section{Oranges}

Dancy Tangerine. The most productive and profitable for shipping. Size about same as Satsuma, slightly thicker. Ripe February to August. $\$ 3.50$ each.

Washington Navel Orange. (Seedless.) Easily heads the list of California oranges, and by reason of its superiority, is largely responsible for California's world-wide citrus fame. Peel smooth and tough making it an ideal shipper. Ripens November to March. $3 / 4$ " up, $\$ 2.00$ each.

Valencia. The only variety that shares the popularity of the Washington Navel. As the Navel season closes the Valencia season begins and continues through the summer and fall months. Tree strong, vigorous grower, very prolific; fruit medium size, oblong, firrn and heavy; few seeds. Having no competitor when it reaches the market commands good price. Ripens April to October and hangs on tree all winter. $5 / 8$ ", $\$ 1.00$ each; $3 / 4 ", \$ 1.50$ each; under $1 / 2 "$. $75 \mathrm{c}$ each. 


\section{Lemons}

Eureka Lenıon. Leading commercial. lemon Fruit uniform and of medium size, rind of fine texture and color; rich in juice; quality the highest. $\$ 2.00$ each.

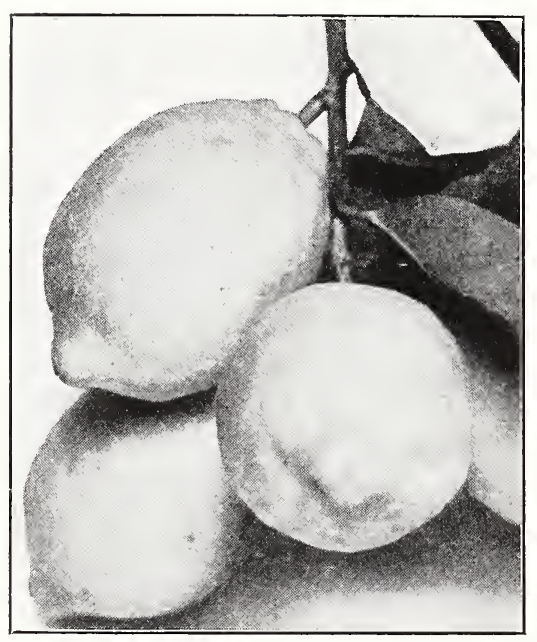

EUREKA LEMON

Marsh Seedless Pomelo. Fruit of good size and practically seedless. Juice abundant and of exceptionally fine fiavor, rich and piquant; rind thin and lemon yellow in color. Tree a vigorous and compact grower and good bearer. March to October. \$2.25 each.

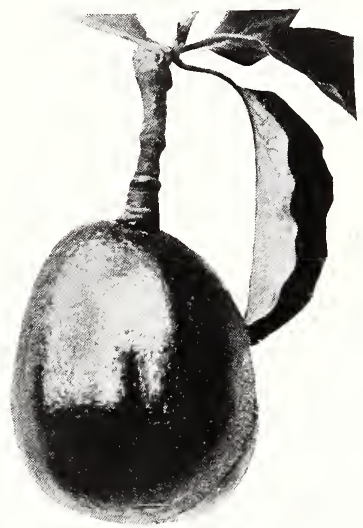

\section{PERFECTO AVOCADO}

\section{Avocados}

Wagner's Seedling. The hardiest and most prolific sort known. Fruit the true Mexican type, skin is thin, dark glossy purple when ripe. It has a small sized seed that fits tight in the cavity. Flesh yellow and has a rich flavor. Ripens September and October: a recommended variety. $25 \mathrm{c}$ to $\$ 1.00$ each.
Fuerte. Fruit pear shaped dull and green in color, matures at an exceptionally good time. Samples of the fruit analyzed as high as $30 \%$ fat or oil, being one of the highest yet tested. Together with all its other good qualities it ranks as one of the best. Fruit from ten to sixteen ounces. Ripens January to March. $3.4 \mathrm{ft}$., $\$ 4.50$ each; $4-5 \mathrm{ft}$., $\$ 6.50$ each.

Dickinson. Thick skinned medium size fruit oval shaped, dark purple in color. Quite hardy and very good shipper. 3-4 $\mathrm{ft}$., $\$ 4.50$ each; $4.5 \mathrm{ft}$., $\$ 6.50$ each.

Northrup. Thin skinned pear shaped avocado of fine texture, very high flavor. Keeps well and bears two crops a year-hardy. $3.4 \mathrm{ft}$., $\$ 4.50$ each; $4.5 \mathrm{ft}$., $\$ 6.50$ each.

Perfecto. One of the best croppers, producins reasonably large fruit with smooth thin black skin, is fair keeper and of good quality. A variety that we can recommend. $3-4 \mathrm{ft} ., \$ 4.50$ each; $4.5 \mathrm{ft}$., $\$ 6.50$ each.

Pueblo. It is the smallest of the recommended varieties, weighing from six to fourteen ounces with a medium-sized seed which fits tightly in the cavity. The flesh is yellow, smooth and of a rich flavor. At a period of eight months from blossom to maturity of the fruit is the shortest of any of the recommended varieties. We recommend very highly for family use. Ripens in December and January. 3-4 feet, $\$ 4.50$ each; 4.5 feet, $\$ 6.50$ each.

\section{Loquats}

We list below four varieties of Loquats, 2 yellow and 2 white varieties, and you can make no mistake in planting commercially any of the 4 varieties but we highly recommend the Wagner's Yellow Pear as being the peer of all others.

Wagner's Yellow Quince. Originated by J. B. Wagner. The shape is the same as a quince and can be readily mistaken for a quince. Light tart in flavor and extra large. One of the best for jellies and for commercial markets; heavy producer. An excellent combination in planting the two varieties originated by Mr. Wagner. Both varieties have proven their merits. Under 2 feet, $75 \mathrm{c} ; 2-3$ feet, $\$ 1.00$ each; $3-4$ feet, $\$ 1.25$ each; 4 feet up, $\$ 1.75$ each.

Pineapple. (Originated by Mr. C. P Taft.) A white variety, round, has been proven a good variety, sweet and juicy, 1-2 feet, 50c; 2 -3 feet, 75 c each; $3-4$ feet, $\$ 1.00$ each; 4 feet up, $\$ 1.50$.

Blush. (Originated by Mr. C. P. Taft.) White variety, long, a good variety and good bearer. Sweet and juicy. Under 2 feet, $50 \mathrm{c}$ each; $2-3$ feet, $75 \mathrm{c}$ each; $3-4$ feet, $\$ 1.00$ each; 4 feet up, $\$ 1.50$.

Wagner's Yellow Pear. (Originated by J. B. Wagner.) Looks like a medium sized yellow pear. Luscious and sweet, produces the largest fruit and the smallest amount of seed of any sort on the market today. The Wagner's Yellow Pear is far superior in every way, both in bearing qualities and hardiness. It is the best for market and home use, and especially for making preserves and jellies. No mistake can be made in the planting of this variety commercially as good profits can be realized. Under 2 feet, 75c each; 2.3 feet, $\$ 1.00$ each; 3-4 feet, $\$ 1.75$ each, over 4 feet, $\$ 1.75$ each. 


\section{DECIDUOUS FRUITS}

\section{Apples}

4-6 feet, 50c Each; \$5.00 Dozen

Delicious. A large apple with a surface almost covered with a brilliant dark red blending to golden yellow at the blossom end. November to April.

Jonathan. Fruit of medium size, rarely large; color, pale yellow, overlaid with red, striped with carmine. Comes into bearing when young. Season November to January.

N. W. Greening. Fruit medium to large: pretty uniform in size and shape; flesh is tinged with yellow, firm, moderately fine, crisp, rather tender, juicy. Season Novem. ber to January.

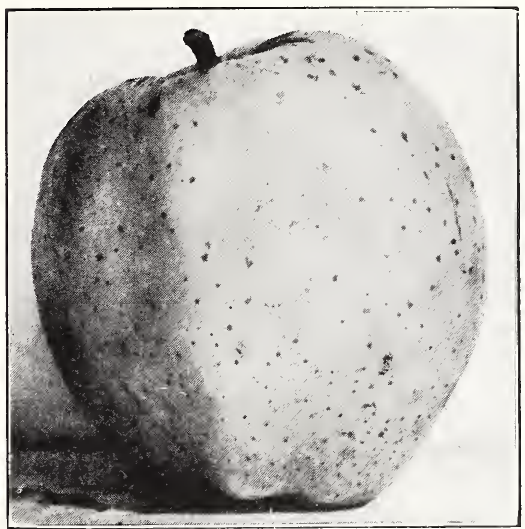

DELICIOUS APPLE

Red Astrachan. Early summer. A beautiful early Russian apple, light and dark red striped and splashed with a bluish bloom.

Red June. Uniform in size and shape, deep red over yellow. Comes into bearing early. Season late July to early winter.

White Winter Pearmain. Large, roundish, pale yellow skin with slight blush, many minute brown dots. Flesh yellowish, tender, crisp, and juicy.

Winesap. Fruit medium, uniform size and shape. Skin smooth, glossy, bright deep red. Season December to May.

Winter Banana. Fruit large, skin moderately thick, waxy, bright pale yellow and occasionally red cheek.

Yellow Bellflower, Skin smooth, bright pale lemon yellow. This is one of the best varieties grown in California for home and commercial purposes.

Yellow Newton Pippin. Smooth greenish yellow skin with brownish red cheek. December to May.

Grimes Golden.

Gravenstein.

Arkansas Beauty.

\section{Crab Apples}

4-6 feet, 50c each

Transcendent. Large golden yellow with red cheek. Fine flavored, hardy and productive, makes good cider.

Hyslop. Fruit medium. Color, yellow rounded with heavy shade of deep crimson, splashes of maroon with heavy blue bloom. It is one of the most desirable for culinary purposes. September to October.

\section{Pears}

\section{4-6 feet, 60c; $\$ 6.00$ Dozen}

Bartlett. Large bright yellow with red blush. The white, fine grained flesh and excellent quality makes Bartlett the leading commercial variety. Ripens August.

Winter Nelis. Medium size, yellowishgreen, dotted russet. Flesh fine grained, rich and sweet with a delicious aromatic flavor. November. In big demand during the holiday season.

\section{Plums 4-6 feet, $60 \mathrm{c}$.}

Burbank. Large red with lilac bloom, flesh deep yellow, very sweet; commences bearing when 2 years old.

Damson. Fruit small oval shaped. Skin purple; flesh juicy, rather tart and very desirable for making jam.

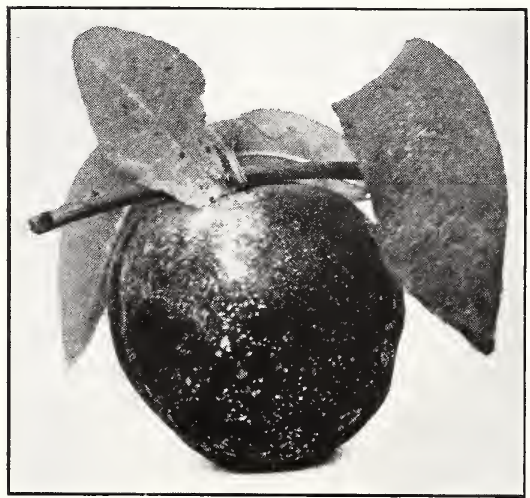

\section{SANTA ROSA PLUM}

Hale. A yellow plum, nearly round; flesh yellowish; one of the eariiest plums grown in California. Sweet and luscious.

Beauty. Bright red, yellow flesh tinged with red. Exceedingly prolific; good size and quality.

Green Gage. Rather small, round, surface green, becoining yellowish green. Flesh pale green, melting, juicy, exceedingly sweet and rich; unequaled in flavor. 
Kelsey. A very large, late, heart shaped plum. Skin mixed yellow and purplish color.

Santa Rosa. Fruit large and fine. When ripe a rich deep purple with amber flesh near the stone. Quality and beauty unsurpassed. Our favorite.

Satsuma. Large, dark red; firm, solid, juicy; delicious flavor, very small pit. Ripens early.

Wickson. Tree a hardy and upright grower. Fruit a deep maroon red, firm, a good keeper; flesh dull yellow, meaty and good quality.

Duarte.

\section{Climax.}

\section{Prunes}

\section{4-6 feet, $60 \mathrm{c}$}

French Prune. Medium size, egg shape violet purple; very sweet and sugary; the most extensively planted for drying.

Italian Prune. A fine late prune, oval, purple; flesh juicy and delicious, parts from the stone; fine for drying.

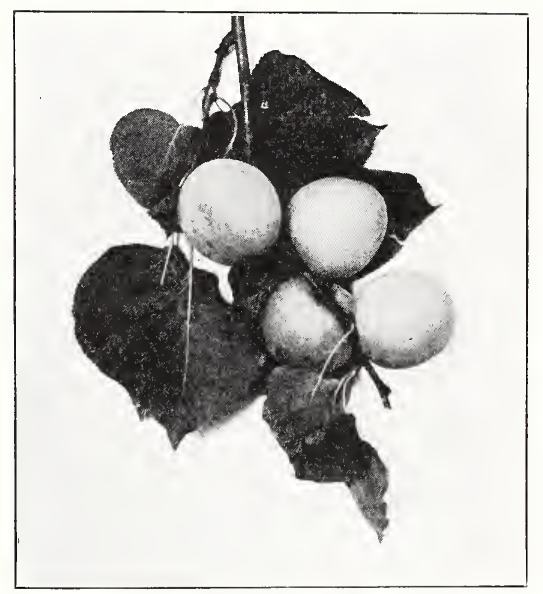

ROYAL APRICOT

Hungarian. Very large, dark brownish purple; eating and canning.

Sugar. Earlier, larger and sweeter than French, not quite so good a dryer. Heavy bearer in some localities, not so good in others.

\section{Apricots}

\section{4-6 feet, $60 \mathrm{c}$}

Blenheim. Fruit large and oval, orange color. Flesh deep yellow, rich and juicy.

Early Golden. Small, surface wholly pale orange. Hardy, very productive. Extra early.

Royal. Medium to large fruit, depending upon the thinning out. Skin yellow, shading to orange. Medium early.

Moorpark. Large variety with orange skin shading to deeper orange or brownish. red. Flesh bright orange, quite firm and juicy with luscious flavor. A favorite.

Newcastle. Tilton.

\section{Peaches}

\section{4-6 feet, $60 c$}

Strawberry. Extremely early peach. Cood variety of the earliest market; white flesh.

Briggs Red May. Fruit large to medium, white skin with rich red cheek, partially free. A good early variety.

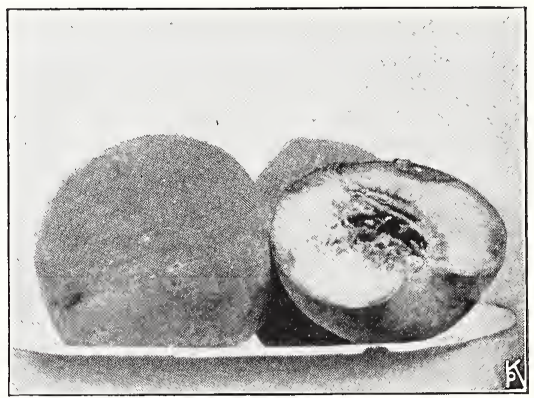

\section{J. H. HALE PEACH}

Sneed. Medium sized fruit, white flesh. Strong grower. A good peach. Extra early. Freestone.

Alexander. An early peach of good quality, medium size, skin greenish-white covered with rich red.

Early Imperial. A heavy grower, fruit large with small pit, skin yellow heavily shaded with dark red.

Early Crawford. A magnificent, large yellow peach of good quality. Its fine size and beauty make it one of the most popular sorts.

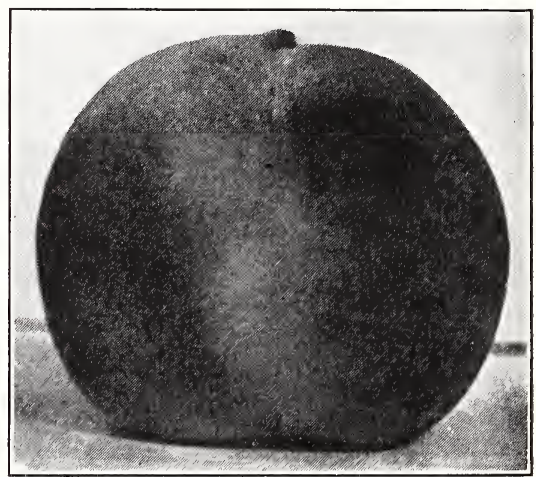

\section{ELBERTA PEACH}

EIberta. Large, bright yellow with a beautiful mottled red cheek; flesh yellow; an excellent market variety. Late in July.

J. H. Hale. About the size of Elberta. Ripens about five days earlier. Color yellow and deep carmine blush.

Foster. Large, deep orange color, turning to red in the sun. Flesh is yellow, rich and juicy, of the finest quality. Ripens ahead of Early Crawford. 
Lovell. Large, round yellow, very uniform. Flesh yellow, firm and richly flavored. A splendid canning, shipping and drying variety. About ten days later than Muir.

Crosby. Fruit medium size, roundish, slightly flattened; bright red cheek; flesh yellow.

Late Crawford. Large, round, with deeper coloring than Early Crawford.

Muir. Excellent quality; flesh yellow clear through; pit small, one of the most popular for canning and drying. Yellow freestone.

Salway. Fruit large and roundish; deep yellow with a dull red cheek; flesh yellow, firm, juicy and rich; one of the very best late peaches.

Levy Late Cling. (Henrietta.) Very late yellow. A good sort for the home orchard. Ripens 50 days after Elberta.

Phillips Cling. Medium Sort. Fruit large, round with slight blush on the sunny side; firm, yellow to the center.

Heath Cling. Late Sort. Very large fruit skin downy, creamy white, with faint blush; flesh greenish white.

\section{George Fourth. \\ Mayflower. \\ Tuscan Cling. \\ Late Lancer.}

McClure's Strawberry Cling.

Champion.

\section{Mulberries}

Russian. Very hardy, vigorous grower, fruit of small size and varies in color from white to black. Largely planted for windbreaks, also in chicken yards for shade; fruit fine for chickens. 3-4 feet, 50c; 5-6 feet, $75 \mathrm{c}$ each; $6-10$ feet, $\$ 1.00$

Nor de Spain. Called by some the Logan Mulberry as the berries resemble same in every respect, color and flavor; very tart and is excellent for making jams and jellies. Small, $75 \mathrm{c}$; larger, $\$ 1.25$ each.

Teas Weeping Mulberry. Similar to a weeping willow. $\$ 1.00$ to $\$ 5.00$, according to head.

\section{Nectarines}

\section{4-6 feet, each $60 c$}

Boston. Large, bright yellow with red cheek, flesh yellow, sweet and pleasant flavor. Freestone.

Stanwick. Large size, flesh white, tender and juicy and delicious, skin greenish white.

New White. Fruit round and large. Free small pit; flesh white, rich and delicious; skin white.

\section{Cherries}

\section{4-6 feet, each $75 \mathrm{c}$}

Lambert. A very promising cherry of largest size. Flesh red, firm and of unsurpassed quality. June.

Bing. One of the best black cherries in existence. lt is large, firm and delicious. Middle of June.

Napoleon or Royal Anne. Very large; pale yellow with bright red cheek; very firm juicy and sweet. First of July.

Richmond. Medium size; dark red, melting, juicy, sprightly acid flavor. This is one of the most valuable and popular of the acid cherries. Ripens through June.
English Morello. The best sour variety of cherry for Southern California. Medium tó large, blackish red; very productive.

Compass. Tree a good grower. Fruit small red. Called either plum or cherry. It does well where other cherries fail.

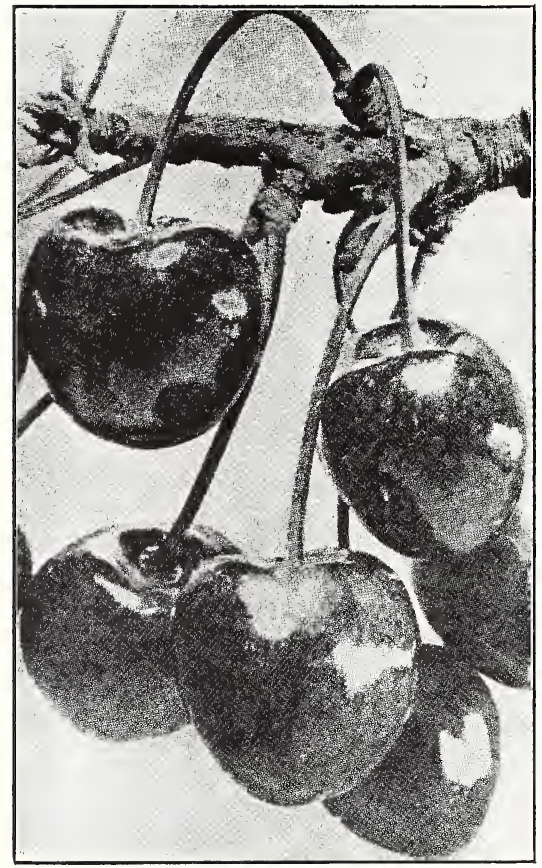

\section{BING CHERRY}

\section{Persimmons}

4-6 feet, Each, \$1.50; Dozen, \$15.00 2-3 feet, Each, \$1.00; Dozen, $\$ 8.00$

Hachiya. Large, conical, bright red. Flesh vellow; of highest flavor. Finest for California planting. Few seeds. Early ripening.

\section{Quince}

\section{3-4 feet, $40 \mathrm{c}$; 4-6 feet, $50 \mathrm{c}$}

The Quince is becoming more popular each year as new uses are found for it. There is no fruit that can equal it as a filler for salads after being preserved, having a piquancy in taste that is as unusual as it is delightful.

Orange. Large, golden yellow; firm, ten der flesh, excellent flavor; strong and thrifty grower; best for preserves.

Pineapple. Large size, smooth and round. lt may be eaten as an apple after being thoroughly ripened; will keep indefinitely.

Smyrna. The fruit of this superb variety is very large and of a lively, lemon yellow color, tender and delicious when cooked.

Angers. A very hardy and strong growing variety.

Champion. One of the old stand-by varieties and more grown than any other sort. 

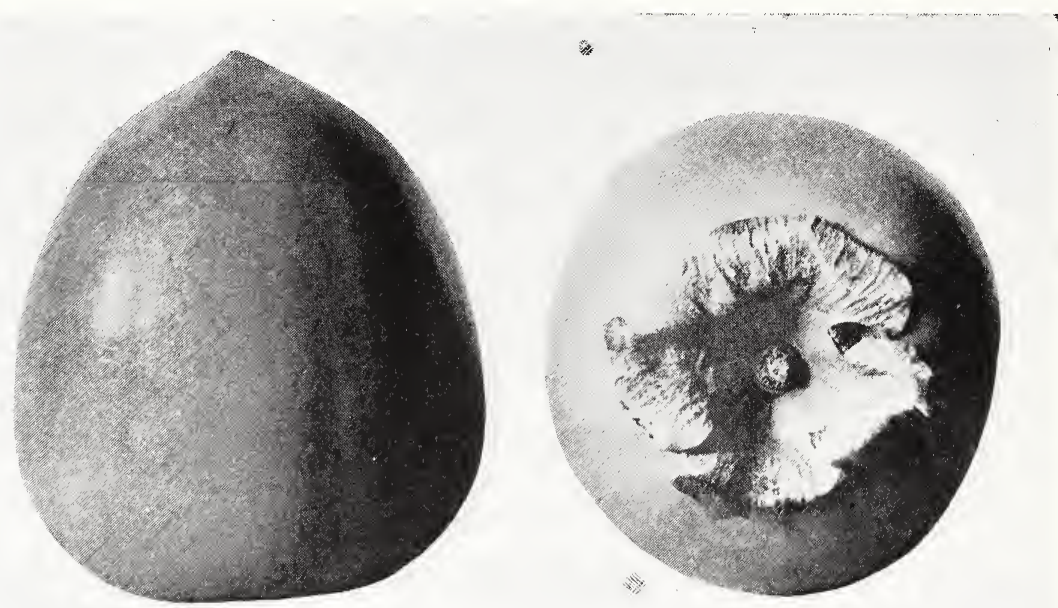

HACHIYA PERSIMMON

\section{Pomegranates}

Pomegranates. Double flowering. Red, white and variegated. The double flowering varieties are excellent for lawn planting with other shrubbery; blooms the larger part of the summer months. $50 \mathrm{c}$ to $\$ 1.00$.

Wonderful. A recent introduction of great merit. Large, highly colored and attractive. Pulp bright garnet. Abundance of juice and excellent flavor. Valuable for snipping to Eastern markets. October. 3-4 leet, $40 \mathrm{c}$; 4-6 feet, $60 \mathrm{c}$

Large Fruited. Tested by the government. It is the largest fruiting variety grown at this time. Seeds are bright red and good taste, rind thin. A highly recommended variety, $50 \mathrm{c}$ to $75 \mathrm{c}$.

\section{Figs}

\section{3-4 feet, Each, 50c; Dozen, \$4.0u,} 4-6 feet, Each, 60c; Dozen, \$6.0u

Mission, or California Black. The only black fig that is dried commercially in California. Hardy and productive wherever the fig can be grown. Fifteen degrees above zero will $n^{\prime}, t$ injure the tree when dormant. it is now grown where thought impossible a few years ago. Strong upright grower and sure cropper. Bears young.

White Adriatic. Large; skin greenishyellow; flesh reddish; tree strong grower and prolific; largely planted in California.

White Pacific. The best of all figs for home use. Medium size; skin thin, yellowish-green; flesh light yellow. Does not crack or sour when ripe. August to November.

Honey or Rose Blanco. Medium to large; roundish, long stalk, brown and white skin; flesh bright red. One of the best varieties grown today, and the sweetest; no mistake will be made in planting this variety as it is a heavy producer and suitable for table and commercial purposes.
Celeste. A small variety of amber color. Pulp reddish; slow grower, heavy cropper; good for home consumption. Very sweet and fine for preserves; the hardiest known fig. Will stand near zero weather.

Kadota. Sometimes sold as White Endrich, White Pacific, Vardoni, etc. The fruit is a good size, thin white skin and white reddish yellow pulp. Absolutely the sweetest and finest flavored fig known. So sugary that it is impossible for it to sour on the tree. Unsurpassed for cooking, canning, eating fresh or served in any manner. No sugar necessary even for preserving. Tree a strong upright grower. Ripens from earliest spring till frost. Bears the first year in the nursery.

San Pedro or California Black. Early; large, sweet, amber pulp. Very good for desert sections. 2 crops.

Smyrna. Largest and finest for California; large flat type with yellow skin; pulp reddish amber; very fine for drying.

Brunswick. Large, light brown with purple cheek; good bearer and fine market variety.

Brown Ischi. Very similar to Brunswick, only longer and sweeter; does not crack so readily.

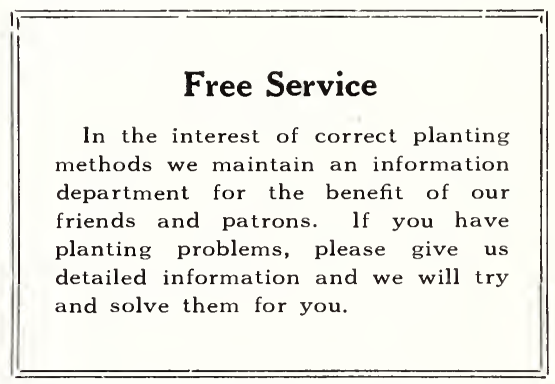




\section{THE NUT FRUITS}

\section{Walnuts}

Wagner's Giant Black. The best and quickest growing walnut for timber grown at this time. A tree in the nursery row six years after planting measured over two feet in diameter at the base. A representative of the Departiment of Agriculture from Washington, D. C., after seeing the tree said it was the most extraordinary growth of a walnut or hardwood tree he had ever seen. This statement is one by itself, and enough to con. vince any man to plant this tree for timber or shade. A good feature of this hybrid is that the seeds will prove true to parentage when planted, which is another good factor to its credit. The nuts resemble English hard shell and have a sweet kernel, of course not as desirable as the English, but is excellent for culinary purposes.

Practical tests of the timber have dernonstrated beyond doubt the best of all walnut timber, being tough, close grained, and of fine texture. lt is highly recommended for roadside planting and shade planting, on account of it being a fast grower, and will do well in any aluvium soil and needs little care after being established. If you contemplate the planting of ground for timber we advise the planting of Wagner's Giant Black and you will not be disappointed in the returns. We have a booklet that gives more information about Wagner's Giant. Write for it.

Prices: Under 2 feet, $25 \mathrm{c}$ each; $\$ 2.00$ per dozen; $\$ 12.50$ per hundred; $2-3$ feet, 50c each, $\$ 3.50$ per dozen; $\$ 20.00$ per hundred. We can supply seed of the Wagner Giant Black Walnut, each, 10c; dozen, $75 \mathrm{c}$; hundred, $\$ 4.00$; thousand, $\$ 35.00$.

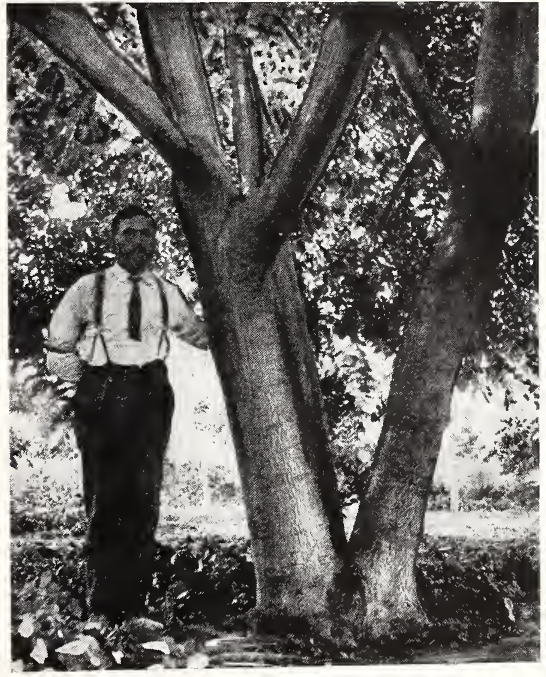

WAGNER'S GIANT WALNUT ( 8 Years Old)

California Black. An exceedingly fast grower, is good for street shade and forest planting. Nuts medium size and sweet, not as highly prized, of course, as the softshelled verieties. 4-6, 75c each; dozen, $\$ 5.00$; hundred, $\$ 40.00$; also $3-4,50 \mathrm{c}$ each; dozen, $\$ 3.50$; hundred, $\$ 20.00$.

Seiboldia. An excellent variety for shade planting; good grower, the leaves being three feet long, which makes it excellent for shade on a lawn. Price same as Wagner's Giant.

English Soft Shell Seedlings. Grown from pedigreed seed of the Santa Barbara, Eureka, pedigreed seed of the Santa Barbara, Eureka, 2 feet, same as Wagner Giant; over 2 feet, at $50 \mathrm{c}$ each; $4-6 \mathrm{ft} ., 75 \mathrm{c} ; 10$ to $12 \mathrm{ft}$., $\$ 2.00$.
Franquette. Late bloomer, hardy with dense foliage; does very well for northern part; large elongated nut, smooth, tightly sealed, with full sweet kernel.

Placentia (Budded). Commonly known as Placentia Perfection. Still remains the most popular and profitable walnut grown in Southern California. Kernels are full, white. meated and are of excellent flavor and quality. 6.8 feet, $\$ 1.25$ each. 3.4 feet, $75 \mathrm{c}$ each.

Eureka (Budded). Upright and vigorous grower, clean branches and open growth, slightly rough bark and not subject to sunburn; recommended as one of the best producers. $3-4 \mathrm{ft} ., 75 \mathrm{c} ; 6-8 \mathrm{ft} ., \$ 1.25 ; 8-10 \mathrm{ft}$., $\$ 1.75$.

\section{Pecans}

Daisy Seedlings, Our experience has proved that very fine results are obtained from these trees, grown from selected seed from isolated trees in our own orchard, and we highly recommend them for California conditions as they are very hardy and produce constantly very heavy crops of a large delicious nut. We can supply in large or small quantities. Each $35 \mathrm{c}$; dozen, $\$ 300$. hundred, $\$ 20.00$. Large specimens $\$ 1.00$ each.

Daisy Grafted. $4-6 \mathrm{ft} ., \$ 2.00 ; 2.4 \mathrm{ft}$., $\$ 1.00$.

\section{Almonds}

4-6 feet, 60c

I. X. L. Tree a sturdy, rather upright grower with large leaves; nuts large with, as a rule, single kernels; soft shell.

Nonparicl. Of a weeping style and growth, smaller foliage than the 1. X. L. An extraordinary heavy and regular bearer; thin shell.

Drake's Seedling. Nut medium size, roundish; shell soft; blooms late; bears abundantly; a popular commercial sort. 


\section{CONIFEROUS TREES AND SHRUBS}

\section{Cedrus}

Cedrus deodara (Himalayan Cedar). The most popular of all cedars; foliage of silvery blue, very graceful and impressive. Attains great size and height; fast grower. Balled and cans, $\$ 3.00$ to $\$ 6.00$.

\section{Chamaecyparis}

Chamaecyparis lawsoniana (Lawson Cypress). Pyramid, oval, broad shaped tree, soft gray in color with graceful outlines; a splendid tree for lawns; hardy, except in too dry a climate. Gal. cans, $60 \mathrm{c}$ to $75 \mathrm{c}$; balled, $\$ 1.50$ to $\$ 2.50$.

\section{Cryptomeria}

Cryptomeria japonica elegans. Fast grower; slender bronze-green foliage changing to red bronze in winter. Does not do so well in too dry a climate. Gal. cans, 75c; 5 gal. cans, $\$ 1.50$ to $\$ 3.00$.

\section{Cupressus}

Cupressus arizonica (Arizona Cypress) Silvery gray foliage; hardy and a rapid grower. Makes attractive hedge; has tapering habit. Gal. cans, $50 \mathrm{c}$ to $75 \mathrm{c}$; balled and boxed, $\$ 1.50$ to $\$ 6.00$.

C. macrocarpa (Monterey Cypress). The common variety, used mostly for hedges; trims easily to any desired shape; fastest grower of all; foliage bright green, but grows darker with age. Attains fine height in short time. Hedge size, in flats, $\$ 2.50$; gal. cans, $50 \mathrm{c}$ to $75 \mathrm{c} ; 5$ gal. cans, $\$ 1.50$ to $\$ 3.00$.

C. sempervirens (Italian Cypress). Slender, very tall columnar habit, fast growing and hardy. Very effective for entrances. Select compact type. Hedge size, in flats, $\$ 3.50$; gal. cans, $50 \mathrm{c}$ to $75 \mathrm{c}$; balled, $\$ 1.50$ to $\$ 10.00$.

\section{Juniperus}

Juniperus pfitzeriana (Spreading Juniper). One of the very best; wide spreading silvery blue foliage; rapid grower and very hardy. Balled, $\$ 1.50$ to $\$ 3.50$.

\section{Librocedrus}

Librocedrus decurrens (lncense Cedar). Tall, pyramidal form; green flat foliage of the Arborvitae type. Very hardy and always holds its attractive color. Good tree for wide parkings. $\$ 1.50$ and up.

\section{Pinus}

Pinus canariensis (Canary lsland Pine). Upright, slender, open growth; large needles, white in color while young, later a greenish gray; very rapid grower. Balled, $\$ 2.00$ to $\$ 8.00$.

P. radiata (Monterey Pine). Fastest grower and most beautiful of the pines. Bright green foliage; very hardy and most commonly grown in California. Gal. cans, $75 \mathrm{c}$; balled, $85 \mathrm{c}$ to $\$ 2.00$.

P. Torreya californica (California Nutmeg). A rare native tree of spreading habit; foliage long, straight, flattened and acute. Takes its name from the peculiar shape of its fruits. Balled, 2 to $3 \mathrm{ft}$., $\$ 5.00$ each.

\section{Thuya}

Thuya orientalis aurea nana (Ever Golden Arborvitae). Very dwarf type, compact and fine in shape; foliage golden tipped and broad oval shape; quite scarce. Balled, $\$ 2.00$.

T. orientalis (Chinese Arborvitae). This type is not quite so dwarf as the preceding, but of good compact form. Balled, \$1.00 to $\$ 4.00$.

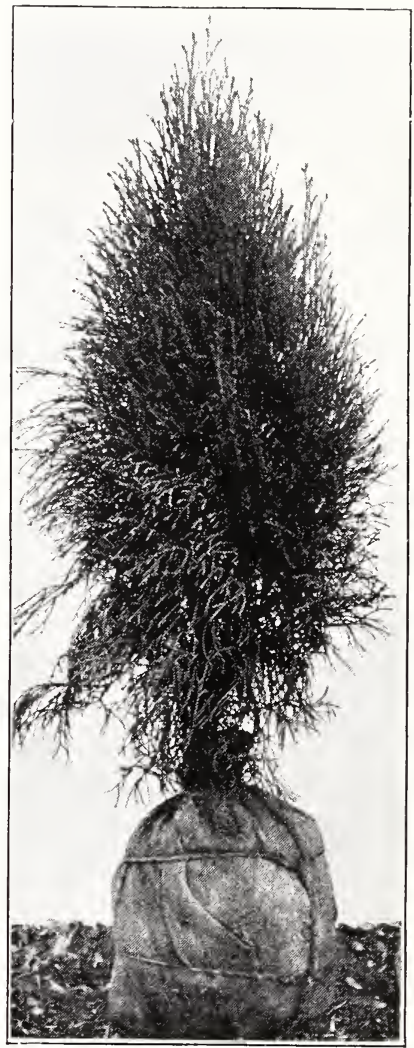

\section{ARBOR VITAE}

\section{Sequoia}

Sequoia sempervirens (Coast Redwood). This well known California Redwood is one of the largest and most picturesque trees known; unexcelled for avenues, parks and gardens; very fast growing upright form. Balled and boxed, $\$ 2.00$ to $\$ 10.00$. 


\section{BROAD-LEAVED EVERGREEN TREES}

\section{Acacia}

Acacia armata (Kangaroo Thorn). Fast growing tree, requires little watering; very hardy and will stand considerable heat or hardy and will stand conth yellow flowers. Gal. cans, $75 \mathrm{c}$; 5 gal. cans, $\$ 1.50$.

A. Baileyana. Handsome tree with deep silvery blue fern-like foliage with rich golden flowers in February and March; quite hardy; does best if planted while young; a tree of rare beauty. Gal. cans, $75 \mathrm{c} ; 5$ gal. cans, $\$ 1.50$.

A dealbata (Silver Wattle). $50-60 \mathrm{ft}$. Foliage resembles that of Baileyana, though the tree is more hardy and longer lived. Fine for streets. Gal. cans, $75 \mathrm{c} ; 5$ gal. cans, $\$ 1.50$.

A. floribunda (A. nerifolia). "Everbloom ing Acacia." 18-20 ft. This tree blooms constantly; creamy yellow balls, very fragrant. Gal. cans, 75c; 5 gal. cans, $\$ 1.50$.

A. melanoxylon (Black Acacia). This tree is well known in Southern California; foliage more dense than the other Acacias, with long flat leaves, flowers lighter color. Hardy. Gal. cans, from $75 \mathrm{c}$ to $\$ 1.50$.

\section{Aralia}

Aralia papyrifera (Chinese Rice Paper Plant). Tall shrub; very rapid grower; though damaged some by heavy frost, it quickly recovers. Tropical in appearance. Gal. cans, $75 \mathrm{c} ; 5$ gal. cans, $\$ 2.00$.

\section{Berberis}

Berberis Darwinii (Darwin's Barberry). Dark green foliage with beautiful saffron flowers blooming in the spring. Rather difficult to grow in Southern California as it is frost resistant and grows well under sharper conditions. Gal. cans, 75c; 5 gal. cans, $\$ 1.50$.

\section{Camphora}

Camphora officinalis (Camphor Tree). Tree of moderate height and regular form; desirable as a street tree and planted as a single specimen; foliage dense and a bright glossy green; hardy. Gal. cans, $75 \mathrm{c}$.

\section{Ceretonia}

Ceretonia siliqua (Carob Tree, St. John's Bread). Though a fruit bearing tree, it is really more desirable as an ornamental. Very drought resistant. Gal. cans, $50 \mathrm{c}$ to $\$ 1.00$.

\section{Casimiroa}

Casimiroa edulis (White Sapote). Drought resistant; does best in warm locations. Gal. cans, 75c.

\section{Casuarina}

Casuarina stricta (She Oak). Fast grower and hardy, somewhat resembling the Pine, very fne for narrow places, such as parkings. Tall and upright. Gal. cans, $50 \mathrm{c}$ to $75 \mathrm{c} ; 5$ gal. cans, $\$ 1.50$.

\section{Eucalyptus}

Eucalyptus citriodora (Lemon Scented Gum). Tall slender tree with clear gray bark, easily frosted while young; drought resistant. Gal. cans, $50 \mathrm{c}$ to $75 \mathrm{c} ; 5$ gal. cans, $\$ 1.50$ to $\$ 2.50$.

E. ficifolia (Scarlet Flowering Gum). Considered one of the most beautiful of all Eucalyptus; a very compact tree with dark glossy leaves and clusters of brilliant blossoms ranging from pink to crimson. Gal. cans, $50 \mathrm{c}$ to $75 \mathrm{c} ; 5$ gal. cans, $\$ 1.50$ to $\$ 2.50$.
E. globulus (Blue Gum). Very good for streets and parkings; one of the fastest growing trees. The wood is white, hard and close grained; very durable. Gal, cans, $50 \mathrm{c}$ to $75 \mathrm{c} ; 5$ gal. cans, $\$ 1.50$ to $\$ 2.50$.

\section{Euonymus}

Euonymous japonica argenteo-marginata (Silver-Edged Euonymus). Slightly variegated leaves, silver margined, very fast grower and hardy. Gal. cans, $75 \mathrm{c}$; balled, $\$ 1.50$.

E. japonica aurea marginata (Golden Edged). Although a slow grower and dwarf like, this plant is very good for formal plantings and as a tub plant. Foliage bright gold color with a lighter edge. Balled, $\$ 1.00$ to $\$ 2.00$.

\section{Ficus}

Ficus elastica. The common rubber tree and one of the hardiest potted plants for inside or porch decoration. Large, thick, waxy leaves. 6 in. pots, $\$ 1.00$ to $\$ 1.25$.

\section{Grevillea}

Grevillea robusta (Silk Oak). Very fast and hardy grower; flowers of a lovely orange color produced during the early part of summer; requires some pruning to retain size and growth. Gal. cans, $50 \mathrm{c}$ to $75 \mathrm{c} ; 5$ gal. cans, $\$ 1.50$.

\section{Jacaranda}

Jacaranda mimosaefolia. Light green fern like foliage; round upright form when mature. In spring blossoms of light blue appear; easy to grow. Gal. cans, $75 \mathrm{c}$ to $\$ 1.00 ; 5$ gal. cans, $\$ 1.50$ to $\$ 2.50$.

\section{Magnolia}

Magnolia grandiflora (Evergreen Magnolia). Slow growing but very beautiful, reaching a height of 50 to 60 feet. Very fragrant with pearly white blossoms and dark glistening foliage; grows best in a heavy soil; needs planty of water; good for street or parking. Gal. cans, $75 \mathrm{c}$ to $\$ 1.00$.

\section{Quercus}

Quercus agrifolia (California Live Oak). A most picturesque tree for California. This variety is the best known with medium sized toothed leaves, and makes a dense beautiful tree, even when small; a rapid grower. Gal. cans, $75 \mathrm{c}$; 5 gal. cans, $\$ 1.50$.

\section{Schinus}

Schinus molle (Pepper Tree). This tree needs no description it is so well known; of easy culture enduring practically all extremes in weather conditions; particularly desirable for warmer climates. Excellent street tree. Gal. cans, $40 \mathrm{c}$ to $75 \mathrm{c} ; 5$ gal. cans, $\$ 1.50$.

\section{Tamarix}

Tamarix articulata (Evergreen Tamarix, or Athel). Exceedingly fast growing evergreen tree. Very hardy, thriving in most extreme heat and drought and standing considerable frost. Upright trees, drooping branches, fine needle-like foliage, soft gray color. A beautiful tree and a good windbreak. Grows readily from unrooted cuttings. 1-foot cuttings, 25c each; $\$ 12.00$ per 100. Cans, 4 feet, $\$ 1.00$. 


\section{BROAD-LEAVED EVERGREEN SHRUBS}

\section{Abelia}

Abelia grandiflora. 5 to 6 feet. Sharp pointed glossy foliaged spreading shrub, with clusters of small white bell-shaped flowers, blooming from June to October. Gal. cans, $60 \mathrm{c} ; 5$ gal. cans and balled, $\$ 1.00$ and $\$ 1.50$.

\section{Arbutus}

Arbutus unedo (Strawberry Tree). Medium sized bushy shrub similar to California Holly; white bell-shaped flowers in summer followed by red strawberry like fruit about Christmas time. Will stand considerable heat, cold and drought. Balled, $\$ 1.00$ to $\$ 3.50$.

\section{Aspidistra}

Aspidistra lurida. A dark green plant with broad leaves; one of the hardiest plants for indoor culture; planted in open prefers a shady situation. $15 \mathrm{c}$ per leaf.

\section{Buddleia}

Buddleia asiatica. Very fragrant tall growing, bushy-like shrub blooming in the early spring. Requires some trimming. Gal. cans, $50 \mathrm{c}$ to $75 \mathrm{c}$.

B. superba. Very much resembles the preceding, except for a profusion of rosepurple flowers borne in the late summer. 2 to $3 \mathrm{ft}$., in gal. cans, $60 \mathrm{c} ; 3$ to $4 \mathrm{ft}$., $75 \mathrm{c}$.

\section{Buxus}

Buxus japonica (Japanese Boxwood). The fastest grower of the Boxwoods, with round glossy yellowish leaves; requires some trimming; color somewhat effected by frost in winter. Flats, $\$ 4.00$ each; balled, $75 \mathrm{c}$ to $\$ 1.50$; trimmed specimens, $\$ 2.50$ to $\$ 5.00$.

B. sempervirens (English Boxwood). Though a slow grower, really better for interior decorations: also fine for porch or lawn. Pyramid, balled, 24 in., \$2.50-container extra; trimmed specimens from $\$ 1.50$ to $\$ 2.00$.

\section{Callistemon}

Callistemon robustus (Bottle Brush) Very hardy fast growing bush, with odd stiff leaves, blossoms of brilliant red. Requires little water; very resistant. Gal. cans, $75 \mathrm{c}$.

\section{Cantua}

Cantua buxifolia. A climbing shrub, with long flowers in colors of orange, yellow and shaded rose. Gal. cans, $75 \mathrm{c}$.

\section{Carissa}

Carissa grandiflora (Natal Plum). Though this shrub recovers quickly it is advisable to plant in situations reasonably free from frost. Glossy dark green leaves with white flowers. Gal. cans, $60 \mathrm{c}$ to $85 \mathrm{c}$.

\section{Ceanothus}

Ceanothus (California Wild Lilac). Very hardy fast growing shrub, needs very little water; flowers in spray of blue and white. 18 to 24 in., in cans, $75 \mathrm{c}$.

\section{Cestrum}

Cestrum auranticum. Grows to a good height; flowers in sprays of orange or copper, followed by beautiful white berries. 18 to 24 in., in cans, $75 \mathrm{c}$.

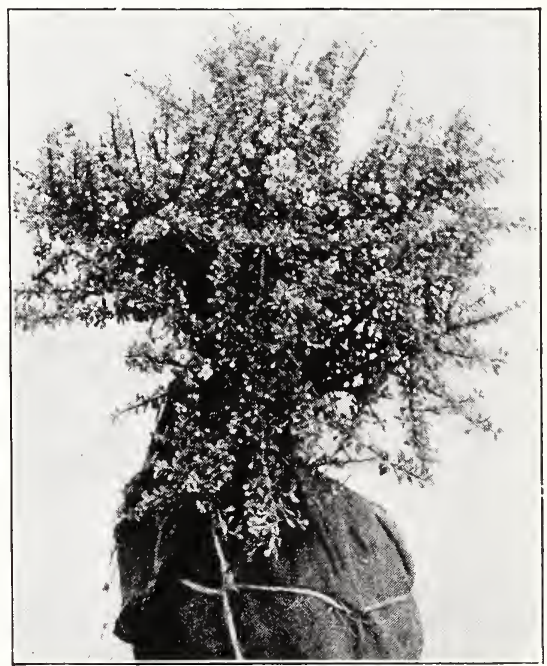

COTONEASTER MICROPHYLLA

\section{Choisya}

Choisya ternata (Mexican Orange). Bushy shrub of bright green foliage with clusters of white flowers at end of branches. Very fragrant. Balled, 18 in., $\$ 1.50 ; 24$ in., $\$ 2.00$

\section{Chorizema}

Chorizema ilicifolium. Blossoms in spring months with delicate pansy-like flowers, slender wiry stems, somewhat resembling holly; a very attractive dwarf shrub when trimmed. 5 in. pots, $35 \mathrm{c}$; gal. cans, $75 \mathrm{c}$.

\section{Cistus}

Cistus ladeniferus maculata (Spotted Rock Rose). A very hardy fast growing shrub; dense foliage with large blossoms of maroon and white. Gal. cans, $75 \mathrm{c}$.

\section{Coprosma}

Coprosma baueri. Low growing shrub that can be trained to a pillar. The roundish green leaves are very glossy and beautiful. Flowers inconspicuous, but followed by clusters of showy yellow berries. Cans, 1.2 feet, 60c.

\section{Cotoneaster}

Cotoneaster buxifolia. Upright growing shrub; dark green foliage, with clusters of bright red berries remaining for severa months. Gal. cans, $75 \mathrm{c}$. 
C. francheti. An upright fast growing shrub with silver and dark green foliage and white flowers followed by red berries. Gal. cans, $75 \mathrm{c} ; 5$ gal. cans and balled, $\$ 1.50$ and up.

C. harroviana. Somewhat resembles Pannosa, but with a darker and more dense foliage. Gal. cans, $75 \mathrm{c}$; balled, 15 in., $\$ 1.25$.

C. horizontalis. During the winter months this shrub bears scarlet foliage and is practically deciduous while during the remainder of the seasons has bright shiny green foliage. Gal. cans, $75 \mathrm{c}$; balled, $\$ 1.25$ to $\$ 1.50$.

C. microphylla. Shiny dark green foliage, bearing white flowers followed with red berries; is of flat spreading type. Cans, 15 to $18 \mathrm{in.}, 35 \mathrm{c}$ to $50 \mathrm{c}$; balled, $75 \mathrm{c}$ to $\$ 1.75$.

C. pannosa. Though quite upright, it is one of the most graceful; foliage of soft gray, under side silver in color, white flowered in spring followed with dull red berries. Gal. cans, $50 \mathrm{c}$ to $75 \mathrm{c}$; balled, $\$ 1.50$ to $\$ 2.00$.

\section{Diosma}

Diosma ericoides (Breath of Heaven). A dwarf bushy shrub with fine heather-like foliage, in the spring flowered with tiny white blossoms on ends of twigs; very fine for a low shrub. Gal cans, $75 \mathrm{c}$.

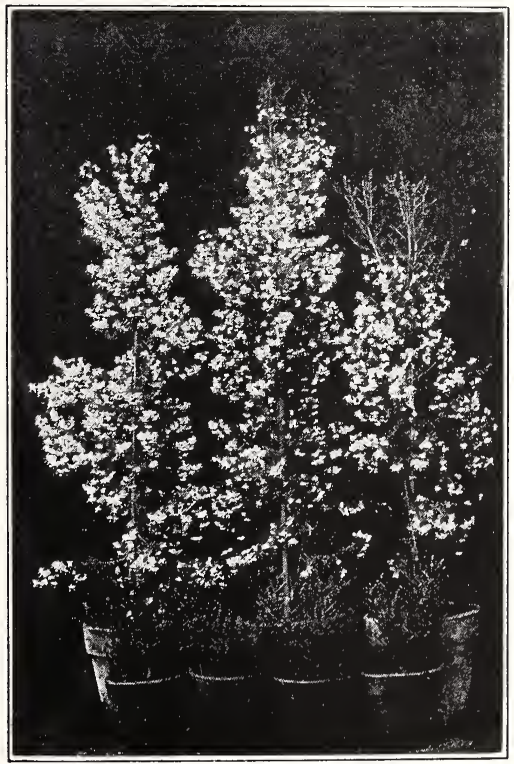

\section{ERICA MELANTHERA}

\section{Erica}

Erica Felix Faure. The most novel and striking of all the Ericas, bearing practically the whole year; has clusters of large tubular rose-red flowers which resemble fire crackers in color. Very beautiful. Pots, 10 to 14 in., $\$ 1.00$ to $\$ 1.50$.

E. Mediterranea. Very hardy dark green shrub, grows quite thick and bushy. Flowers from March to June; dark lavender in color. Balled, $75 \mathrm{c}$ to $\$ 2.00$.
E. melanthera. Most popular of all; commonly called Scotch-Heather; drought and frost resistant; very delicate foliage with blossoms of a pinkish lilac color; useful as a potted plant or as a shrub in the garden. Flowers admirable for cutting. Balled, $75 \mathrm{c}$ to $\$ 2.50$.

E. persoluta alba. Although very hardy, has the most delicate foliage of all, with tiny white bell-like flowers in March and April. Balled, 15 to 18 in., $\$ 1.00$ to $\$ 1.50$; 20 to 24 in., $\$ 1.75$.

E. persoluta rosea. One of the smaller varieties and very compact, with pinkish blossoms. Potted, 10 to 14 in., $\$ 1.00$ to $\$ 1.50$.

E. regerminans ovata. Almost everblooming with rather small pinkish lavender blossoms. Pots, $50 \mathrm{c}$ to $\$ 1.00$; balled, $\$ 1.50$ to $\$ 2.50$.

\section{Escallonia}

Escallonia montevidensis. Large bushy shrub with thick, glossy foliage, white flowers in clusters, moderate grower and one of the best; very hardy. Balled, $\$ 1.50$ to $\$ 2.50$.

E. pulverulenta. Foliage very much the same as the preceding, also with white flowers. Balled, 2 to $4 \mathrm{ft}$., $\$ 1.50$ to $\$ 2.00$.

E. rosea. This type is more useful for massed planting than used singly. Spiked flowers are pink; needs considerable pruning to attain proper shape. Balled, $\$ 1.50$ to $\$ 2.50$.

\section{Eugenia}

Eugenia myrtifolia. Very fast grower, with tall compact habit; foliage glossy green; cream colored flowers followed by violet colored berries. Easily trimmed by pruning. Balled, $\$ 1.00$ up

E. hookeriana. Large foliage with tendency to spread. Needs trimming to attain compact shape. Has attractive purple berries, slightly more rapid grower than myrtifolia. Balled, $\$ 1.00$ to $\$ 1.50$; trimmed specimens, $\$ 2.00$ to $\$ 6.00$.

\section{Gardenia}

Gardenia jasminoides (Cape Jasmine). One of the smaller bushy shrubs, with bright green foliage, white waxy blossoms which appear during the summer. Gal. cans, $75 \mathrm{c}$; balled, $\$ 1.00$ to $\$ 2.00$.

\section{Genista}

Genista canariensis (Canary lsland Broom). Small green leaved shrub, very rapid and slender growth, with small yellow flowers in spring. Gal. cans, $50 \mathrm{c}$ to $75 \mathrm{c}$.

G. Juncea (Spanish Broom). Round dark green stems, practically leafless; does very well without much irrigation. Prolific of lovely yellow flowers during the summer. Gal. cans, $50 \mathrm{c}$ to $75 \mathrm{c}$.

\section{Grevillea}

Grevillea thelemanniana. Blooms constantly unless too cold. Has very bright foliage with flowers of reddish pink, curved to resemble claw; should be pruned. Though injured some by freezing, is heat and drought resistant. Gal. cans, $50 \mathrm{c}$ to $75 \mathrm{c}$

\section{Hibiscus}

Hibiscus Single Scarlet. Though a tender plant, grows very well except in places subject to severe frost; is partial to a sunny situation. Gal. cans, $\$ 1.00$.

H. Single Yellow. Same as preceding, except in color, which is salmon buff with large red eye. Gal. cans, $\$ 1.00$. 


\section{Hydrangea}

These plants do better in shade, although they can be grown in warm places; very large flowers in shape of snowball, in tints of blue or pink, depending on the soil; very fast growing. Gal. cans, $60 \mathrm{c}$ to $75 \mathrm{c}$.

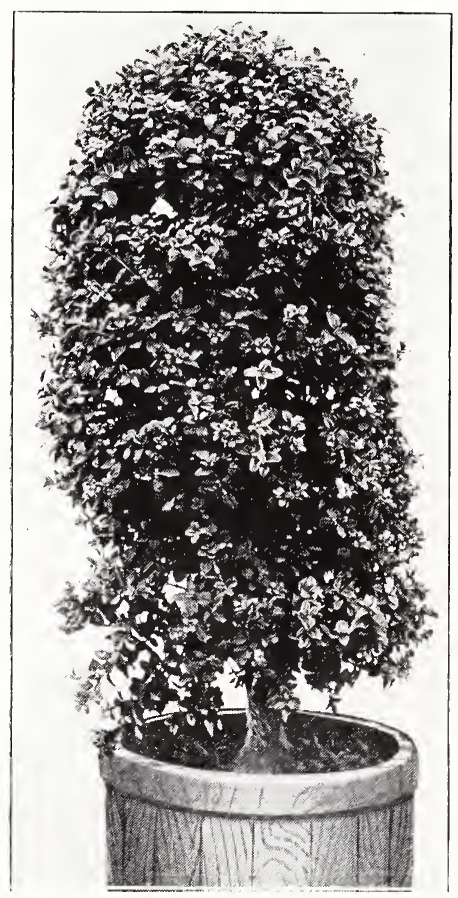

EUGENIA MYRTIFOLIA

\section{Jasminum}

Jasminum primulinum (Primrose Jasmine). Has trailing habit hence good for covering stumps and banks; bright green foliage, with yellow blossoms all through the spring. Very hardy. Gal. cans, $75 \mathrm{c}$.

\section{Lantana}

Semi-dwarf, red, orange, yellow and pink flowering shrubs; highest growth about five feet. Sensitive to frost. Gal. cans, $60 \mathrm{c}$ to $75 \mathrm{c}$.

\section{Lauristinus}

Lauristinus grandiflora. Large glossy leaves and large clusters of white flowers freely borne in winter and early spring. One of the finest evergreen shrubs and hedge plants. Potted, 1 foot, $50 \mathrm{c} ; 1-2$ feet, $75 \mathrm{c} ; 2-3$ feet, $\$ 1.00$.

\section{Laurocerasus}

Laurocerasus (English Laurel). Heavy dense shrub growing to a height of about eight feet; very large dark green leaves; good for heavy hedges. Gal. cans, $75 \mathrm{c}$.

\section{Leptospermum}

Leptospermum laevigatum (Austrian Tea Tree). Graceful, growing quite tall, small grayish foliage covered in the spring with white flowers; very hardy; fine for low windbreaks and hedges. Gal. cans, $35 \mathrm{c}$ to $50 \mathrm{c}$; balled, $\$ 1.00$ to $\$ 3.00$.

\section{Leonotus}

Leonotus leonurus (Lion's Tail). Fast grower, erect branches with dull orange tassel-like flowers; very unusual looking. Gal. cans, $50 \mathrm{c}$ to $75 \mathrm{c}$.

\section{Ligustrum}

Ligustrum japonicum (Japanese Privet). A large shrub or small tree with leathery dark green leaves and white flowers. Very good tall hedge plant; makes substantial growth. Drought resisting. $\$ 2.50$ per flat.

L. nepaleuse (Napel Privet). Small and dark green leaves, bears spikes of white flowers, one of the best small-leaved hedge plants; stands both heat and cold well. Hedge size, in flats, $\$ 2.50$; gal. cans, $25 \mathrm{c}$ to $50 \mathrm{c}$.

L. ovalifolium aurea (Golden Privet). This variety is desirable for hedges because retaining its foliage in winter much better than the green varieties, and is a brighter color in summer. In flats, $\$ 2.50$; gal. cans, $25 \mathrm{c}$ to $50 \mathrm{c}$.

\section{Mahonia}

Mahonia aquifolia (Oregon Grape). Very beautiful shrub holly-like in appearance; foliage shades from a glossy green to bluish purple and bronze. Blossoms of yellow appear in spring to be followed by blue grape like berries. Very good for low shrubberies. Gal. cans, $50 \mathrm{c}$ to $75 \mathrm{c}$; balled, $\$ 1.00$ to $\$ 2.00$.

\section{Melaleuca}

Melaleuca hypericifolia. Fast upright growth with oval flat leaves, orange scarlet flowers, usually inside of bush. Gal. cans, $75 \mathrm{c}$; balled, $\$ 1.50$ to $\$ 2.00$.

\section{Myrtus}

Myrtus communis (Sweet or English Myrtle). Very good for hedges, standing extremes in weather conditions; small glossy bright green leaves; bushy form; grows quite tall or can be pruned for low type small white flowers in spring. Gal. cans, $35 \mathrm{c}$ to $75 \mathrm{c}$; balled, $\$ 1.00$ to $\$ 2.00$.

M. communis microphylla (German Myr tle). Same type as preceding excepting leaves are smaller and more compact. Gal. cans, $50 \mathrm{c}$ to $75 \mathrm{c}$.

M. communis variegata (Variegated Myr tle). Striped and marked with white mark ings; very attractive. Balled, $\$ 1.25$ to $\$ 2.00$.

\section{Nerium}

Nerium (Oleander). This beautiful shrub does very well throughout the state of California, doing even better in lmperial Valley and Arizona. Hardy and fast growing shrub or tree with almost constant succes sion of brilliant showy flowers; can be obtained in both bush and tree form and in colors of single pink, double pink, single red and double red and white. Balled, \$1.25 to $\$ 3.00$. 


\section{Nandina}

Nandina domestica. A dwarfish upright shrub, leaves compound rich red when young, dark green at maturity with coppery tones in winter; in autumn covered with small red berries. Gal. cans, $60 \mathrm{c}$ to $75 \mathrm{c}$.

\section{Photinia}

Photinia arbutifolia (California Holly, Christmas Berry). Very hardy, fast growing bushy shrub, with bright green foliage producing clusters of red berries that ripen at Christmas time. Drought resistant. Gal. cans, $75 \mathrm{c} ; 5$ gal. cans, $\$ 1.50$.

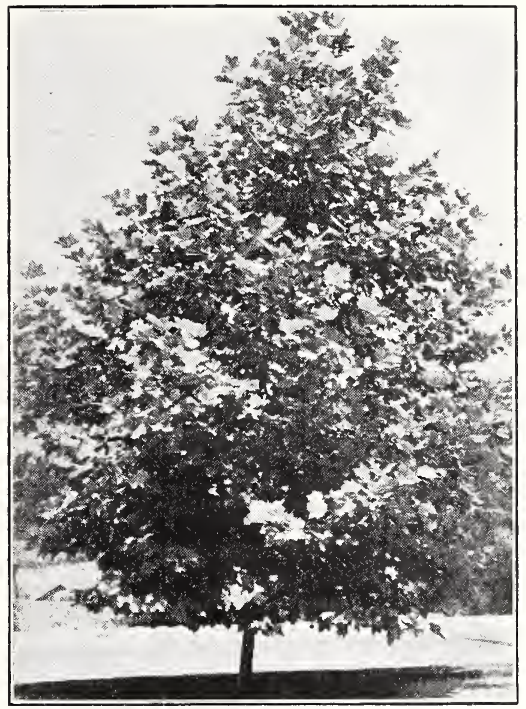

SYCAMORE

\section{Pittosporum}

Pittosporum crassifolium. A tall fast growing shrub rather open with beautiful foliage dark green above, pale green beneath. Gal. cans, $60 \mathrm{c}$ to $75 \mathrm{c}$; balled, $\$ 1.25$ to $\$ 2.00$.

P. eugenoides. Large glossy light green shrub, good for both single and group or hedges. Hardy and quite rapid grower. Gal. cans, $50 \mathrm{c}$ to $75 \mathrm{c}$; balled, $\$ 1.00$ to $\$ 3.00$

P. nigricans (Tenuifolium). Resembles Pittosporum eugenoides in habit but has smaller and greener leaves with distinct black stems. I gal. containers, $50 \mathrm{c} ; 5$ gal. containers, $\$ 1.50$; balled, $\$ 2.00$ and up.

P. tobira. Wide spreading dense round headed shrub, very good for mixed borders. In winter bears lovely white blossoms. Gal. cans, $50 \mathrm{c}$ to $75 \mathrm{c}$; balled, $\$ 1.25$ to $\$ 2.50$.

P. undulatum. Deep green glossy leaved shrub with yellow white blossoms; recovers quickly when frosted; fragrant. Gal. cans, $50 \mathrm{c}$ to $75 \mathrm{c}$; balled, $\$ 1.25$ to $\$ 4.00$.

\section{Plumbago}

Plumbago capensis. Reclining shrub, sun loving, blooms constantly with beautiful blue blossoms covering entire plant. Fine for porches. Gal. cans, $60 \mathrm{c}$ to $75 \mathrm{c}$.

\section{Prunus}

Prunus cerasus integrifolia (Catalina Cherry). Can be used either as a tree or large shrub. Fast growing and very hardy; can be trained for small or tall growth. Gal. cans, $50 \mathrm{c}$ to $75 \mathrm{c}$.

P. Caroliniana (Carolina Cherry). Upright fairly sized, moderate growing shrub; bright green foliage; very hardy. Can be trained for low or tall growth. Gal. cans, $50 \mathrm{c}$ to $75 \mathrm{c}$.

\section{Punica}

Punica (Dwarf Pomegranate) A continuous blooming shrub with small branch ing glossy foliage, scarlet flowers followed by small red fruit; very attractive: fine as a potted plant. 4 in. pots, $30 \mathrm{c} ; 7$ in., $75 \mathrm{c}$

\section{Pyracantha}

Pyracantha angustifolia. Evergreen Haw thorne. Long branches of spreading prostrate habit, bearing clusters of white flowers. Bright orange berries throughout winter Potted, 1 to 2 feet, $75 \mathrm{c}$. Balled, 2 to 3 feet, $\$ 2.00 ; 3$ to 4 feet, $\$ 3.00$.

Pyracantha coccinea lalandi. Tall upright growth, abundant orange colored berries, somewhat hidden by the foliage; a very beautiful shrub. Gal. cans, $50 \mathrm{c}$ to $75 \mathrm{c}$; 5 gal. cans or balled, $\$ 1.50$ to $\$ 3.00$.

P. yunnanensis. Chinese shrub, very vig. orous grower with larger leaves than the preceding; has dark glossy green foliage, with masses of red colored berries during fall and winter. Gal. cans, $50 \mathrm{c}$ to $75 \mathrm{c}$ 5 gal. cans or balled, $\$ 1.50$ to $\$ 3.00$.

\section{Raphiolepis}

Raphiolepsis japonica. One of the finest dwarf shrubs with very dark thick leaves, white flowers followed by grape-like blue berries; very hardy. Gal. cans, $60 \mathrm{c}$ to $75 \mathrm{c}$

\section{Tritoma}

Tricoma aloides (Red Hot Poker). Nar row leaved stemless plant, with flowers three to five feet high borne in brilliant spikes of red and yellow; frost resisting. Gal. cans, 60c.

\section{Veronica}

Veronica buxifolia. This plant is the most compact dwarf type. Small green leaves, spreading round plant, resembles boxwood though more attractive. Balled, $75 \mathrm{c}$ to $\$ 1.25$.

V. cupressoides. Foliage very fine with heavy growth; one of the fastest growing plants, but requires good care and pruning. Gal. cans, $50 \mathrm{c}$ to $75 \mathrm{c}$.

V. decussata. One of the hardiest and most satisfactory; bright green dense foliage with flower spikes of deep blue. Gal. cans, $40 \mathrm{c}$ to $75 \mathrm{c}$; balled, $\$ 1.00$ to $\$ 1.50$

V. Imperialis. Large leaved, ends tipped and edged dark green shrub; very free blooming; large spikes of reddish purple flowers; very hardy. Gal. cans, $50 \mathrm{c}$ to $75 \mathrm{c}$; balled, $\$ 1.00$ to $\$ 1.50$.

\section{Viburnum}

Viburnum tinus (Laurustinus). This plant does well in the coastal countries but is somewhat adverse to the interior. A splen did winter shrub, with clusters of pinkish white blossoms during the spring. One of the best hedge plants. Gal. cans, $60 \mathrm{c}$ to $75 \mathrm{c}$. 


\section{DECIDUOUS ORNAMENTAL TREES}

\section{Acer}

Acer dasycarpum (Soft or Silver Maple). This is the fastest growing of all the Maples; foliage light green, silvery underneath; very effective. $35 \mathrm{c}$ and up.

A. rubrum (Red or Scarlet Maple). Only Maple that colors brilliantly in Autumn; very much resembling the Silver and Sugar Maple. $60 \mathrm{c}$ to $\$ 1.75$.

\section{Catalpa}

Catalpa speciosa. Fast growing with large heart shaped leaves; beautiful white trumpet shaped flowers, followed by long narrow seed pods. $50 \mathrm{c}$ and up.

\section{Liriodendron}

Liriodendron tulipifera (Tulip Tree). A very beautiful tree; grows to a height of 60 feet, trunk resembles a ship mast; one of the best. $75 \mathrm{c}$ and up.

\section{Melia}

Melia azedarach umbraculiformis (Texas Unbrella). Too well known to require a description; excellent as a shade tree: $50 \mathrm{c}$ and up.

\section{Morus}

Russian Mulberry. Hardy grower; fine for shade or wind breaks; does well in very hot climate. $35 \mathrm{c}$ and up.

Teas Weeping Mulberry. Very beautiful as a tree or shrub; foliage bright green and dense; easily trained to form arbors, etc. $\$ 2.00$ and up.

\section{Platanus}

Platanus (Sycamore). Hardy fast growing trees reaching a height in some instances of 100 feet. Grow with little water. White and gray bark with seed balls on slender stems. $75 \mathrm{c}$ and up.

\section{Populus}

Populus deltoides carolinensis (Carolina Poplar). A hybrid of the cottonwoods more regular in form, makes a large tree quickly, but is not long lived. $35 \mathrm{c}$ and up.

P. nigra italica (Lombardy Poplar). Very effective along roadsides or driveways; is probably the most hardy of all the Poplars; good for landscaping. $60 \mathrm{c}$ and up.

Chinese Poplar. Very different foliage and very decorative. 4 feet, $\$ 1.00$.

\section{Prunus}

Prunus persica (Flowering Peach). The entire tree is one mass of blossoms appearing before the leaves do, making a gorgeous array of color. Desirable for back yards as the tree is not attractive after the blossoms fall. $75 \mathrm{c}$ and up.

Prunus pissardi (Purple Leaved Plum). Upright round headed tree, growing from twenty to twenty-five feet. Foliage bronze purple in color. Bright red round fruit, showy and good for jelly. Very hardy. $75 \mathrm{c}$ and up.

\section{Salix}

Salix babylonica (Weeping Willow). Fast grower, but short lived unless grown near water, to which the roots have free excess. Grows spreading when planted in suitable locations. 4 to $5 \mathrm{ft}$., $60 \mathrm{c} ; 7$ to $8 \mathrm{ft}$., $\$ 1.00$ to $\$ 1.50$.

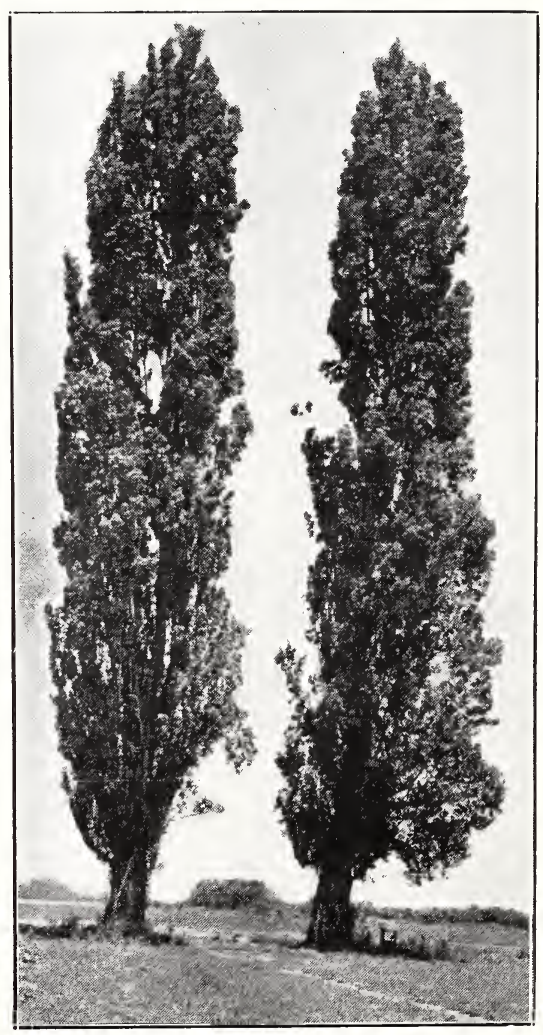

\section{LOMBARDY POPLAR}

\section{Tamarix}

Tamarix caspica. Blossoms in early spring, before foliage appears; flowers soft pink; very beautiful dark foliage. Hardy; grows well in hot climates. $75 \mathrm{c}$ and up.

\section{Ulmus}

Ulmus americana (American or White Elm). A very fine shade tree growing as high as eighty feet; a fast grower and very hardy. $35 \mathrm{c}$ and up.

Cork Elm. Very much the same as American Elm, but the bark is rough and ridged resembling cork. Must have plenty of room to grow. $75 \mathrm{c}$ and up. 


\section{DECIDUOUS SHRUBS}

\section{Almond}

Almond Flowering. Soft fluffy flowers from top to bottom, blooming early in spring before leaves appear; in its season one of the most beautiful shrubs. $\$ 1.00$ to $\$ 2.50$.

\section{Hibiscus}

Hibiscus (Althea). Brightest and freest bloomer during summer months. Very hardy, double and single. Amplisseums Purple; Panerfloures - White and Pink: Rosea-Pale Pink. Gal. cans, $75 \mathrm{c}$ to $\$ 1.50$.

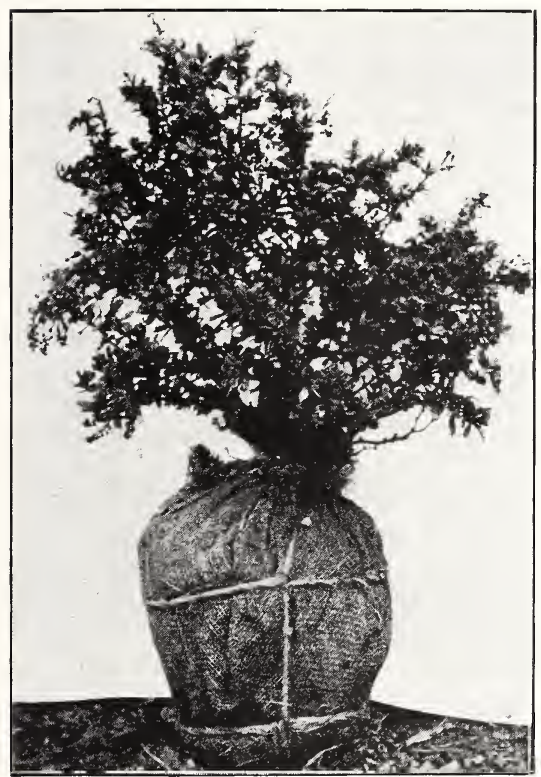

BERBERIS

\section{Berberis}

Berberis thunbergi (Japanese Barberry). Dwarf spiny bush; small bright green leaves which turn to red in autumn. Very effec. tive for hedges. Gal cans, 75c.

\section{Buddleia}

Buddleia variabilis magnifica (Butterfly Bush). Bushy shrub with blossoms in long purple spikes, resembling Wistaria; flowers form June to November; one of the best of shrubs. Gal. cans, $75 \mathrm{c}$.

\section{Calycanthus}

Calycanthus floridus (Sweet Shrub). Dark leaved bushy shrub with many petaled flowers of dark chocolate color blooming in spring; very fragrant. Gal. cans, $50 \mathrm{c}$ to $75 \mathrm{c}$.

\section{Cercis}

Cercis canadensis (Red Bud). Plant covered with small pink blossoms during early spring before leaves start. Gal cans, $75 \mathrm{c}$; 5 gal. cans, $\$ 1.50$ to $\$ 2.00$.

\section{Deutzia}

A group of extremely beautiful and free blooming shrubs. Very hardy and fast growing. 3 feet, $60 \mathrm{c} ; 4$ feet, $75 \mathrm{c} ; 6$ feet, $\$ 1.25 ; 8$ to 10 feet, $\$ 2.00$.

\section{Forsythia}

Forsythia viridissima (Golden Bell). One of the earlier blooming shrubs; golden yellow blossoms; quite showy and very hardy. Gal. cans, $75 \mathrm{c}$.

\section{Lippia}

Lippia citriodora (Lemon Verbena). Fast grower and very hardy. Foliage with strong lemon fragrance. Gal. cans, 75c.

\section{Lonicera}

Lonicera (Honeysuckle) Ornamental deciduous shrubs of upright habit; rarely evergreen. Flowers varying in color from white to yellow, and from pink to scarlet and purple; very fragrant. Gal. cans, 75c 5 gal. cans, $\$ 1.50$.

\section{Myrtle}

Crape Myrtle. Small shrub or tree with an abundance of Crape-like blossoms blooming through the summer and early fall; very attractive. Gal. cans, $75 \mathrm{c}$.

\section{Snowberry}

Sprays and clusters of milk-white berries the size of small marbles cover the 2 to 3 foot bushes in early fall. September to November. Spreading, bushy growth; very attractive. 2 feet, $50 \mathrm{c}$; 3 feet, $75 \mathrm{c}$.

\section{Spirea}

Spirea van houttei. Spring blooming with flat single white flowers making bush a mass of white arching form. Gal. cans, 75c.

\section{Syringa}

Syringa (Lilac). Grafted varieties, both purple and white. Gal. cans, $75 \mathrm{c}$ to $\$ 1.00$.

\section{Viburnum}

Viburnum opulus sterile (Common Snowball). Well known, name describes its appearance; blooms in March and April with very large clusters resembling snow balls. Gal, cans, $75 \mathrm{c}$.

\section{Weigela}

Weigela (Diervilla). Bushy upright form growing ten to twelve feet tall. Foliage quite large with masses of trumpet shaped flowers in delicate hues. Easy to grow and a very beautiful shrub. $\$ 1.00$ and up.

W. variegated (Kosteriana Variety). Yel low Edge and Nana Varigata-White, both lovely shrubs. Retaining color of shrub al summer. Blossoms shaded light pink. \$1.00 and up. 


\section{PALMS, DRACAENAS AND YUCCAS BAMBOO, ORNAMENTAL FOLIAGED PLANTS}

\section{Chamaerops}

Chamaerops-Trachycarpus excelsa (Japanese Windmill Fan Palm). Very tall trunk, slim and hairy, fan shaped leaves deeply cut, very useful for small lawns or narrow driveways; requires little space; hardy. Gal. cans, $75 \mathrm{c}$.

\section{Cocos}

Cocos Plumosa (Pindo Palm). Tall, upright, graceful and popular. Though effected some by frost, recovers quickly. Not desirable in very cold sections. Smooth and graceful trunk, effective for near house or in pairs or groups in borders. Balled and tubbed, $\$ 5.00$ to $\$ 10.00$.

\section{Dracaena}

Dracaena indivisa. Foliage quite narrow and long. Fast grower; branches irregular. Gal. cans, $75 \mathrm{c} ; 5$ gal. cans, $\$ 1.50$ to $\$ 2.50$; balled, $\$ 3.00$

\section{Kentia}

Kentia belmoreana and forsteriana. Most beautiful palms for interior decoration. Dark green foliage on long graceful arching branches. Warm sheltered places are best for this type. Gal. cans, $75 \mathrm{c} ; 5$ gal. cans, $\$ 2.00$ to $\$ 3.00$.

\section{Phoenix}

Phoenix canariensis (Ornamental Canary Island Date Palm). This is the best and most popular palm for California planting. Thrives well under all conditions; grows rapidly and is very hardy; dark green in color; very stately, ideal for street, avenue, park or lawn. In tubs, $\$ 3.50$ to $\$ 7.00$.

\section{Washingtonia}

Washingtonia filifera (California Fan Palm). This is the only palm native to California growing wild in canyons. Makes a massive trunk, with large leaves fringed with coarse white hairs. Very picturesque; a fast grower and excellent for street planting. In tubs, $\$ 3.50$ to $\$ 7.00$.

\section{Bambusa}

Bambusa vulgaris (Giant Bamboos). Very strong grower, inclined to spread, a little slower than some species though entirely hardy with a graceful shape. 5 gal. cans, $\$ 1.50$ to $\$ 3.00$.

\section{Caladium}

Caladium esculentum (Elephant's Ear). Foliage bright green, large and handsome, somewhat resembling in shape an elephant's ear, hence the name. Strikingly effective on a lawn or in mass effects with other ornamental foliaged plants; must be watered freely to attain best effects. In gal. cans, $50 \mathrm{c}$ to $75 \mathrm{c}$.

\section{Phormium}

Phormium tenax (New Zealand Flax). Excellent plant for lawn or other places where clump effects are desired. Very striking. Dark green foliage ribbon like in appearance. Hardy. $75 \mathrm{c}$ and up.

\section{Cortaderia}

Cortaderia argentea (Pampas Grass). A very hardy grass, bearing large silvery white plumes, growing through the fall months attaining (in some instances) a height of eight to ten feet. Does well in a dry situation; beautiful for landscape effects. Gal. cans, $60 \mathrm{c}$ to $75 \mathrm{c}$.

\section{Musa}

Musa ensate (Abyssinian Banana). Foliage large striped with red, very fast grower. Plant dies after blooming; must be sheltered from heavy winds and frosts. Gal. cans, $75 \mathrm{c}$ to $\$ 1.50 ; 5$ gal. cans, $\$ 2.50$ to $\$ 5.00$.

M. oronoca. More hardy plant than Abysinian, and if frosted recovers quickly, hence should be given a sheltered place, though sunny. Bears fruit. Gal. cans, $75 \mathrm{c}$ to $\$ 1.50 ; 5$ gal. cans, $\$ 2.50$ to $\$ 5.00$.

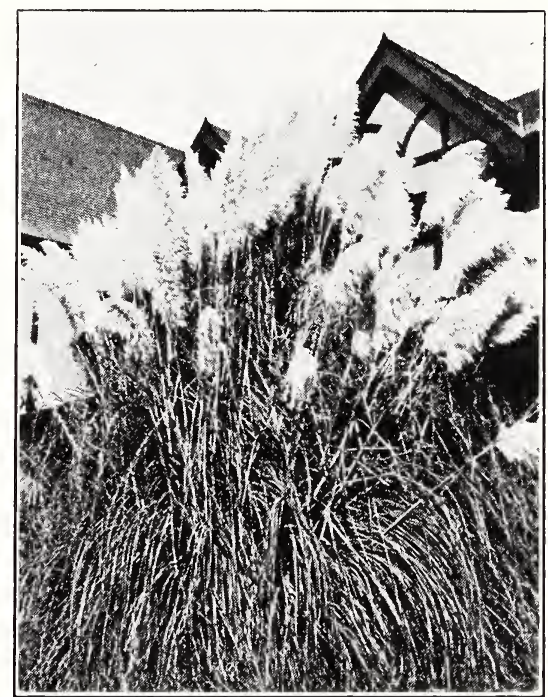

PAMPAS GRASS

\section{Strelitzia}

Strelitzia reginae (Bird of Paradise Flower). Four or five feet tall; foliage about a foot long on two or three foot stalks; color dark green. Flowers parti-colored vividly orange yellow and bluish purple, springing from spathes which stand horizontally. Decidedly showy and attractive when in flower. In 5 gal. cans, $\$ 10.00$.

S. nicoloi. Distinct and individual; grows to a height of from 10 to 18 feet. Foliage oblong acute; flowers in shape resembling a bird and in color varying from pale blue to pure white. In 5 gal. cans, $\$ 10.00$. 


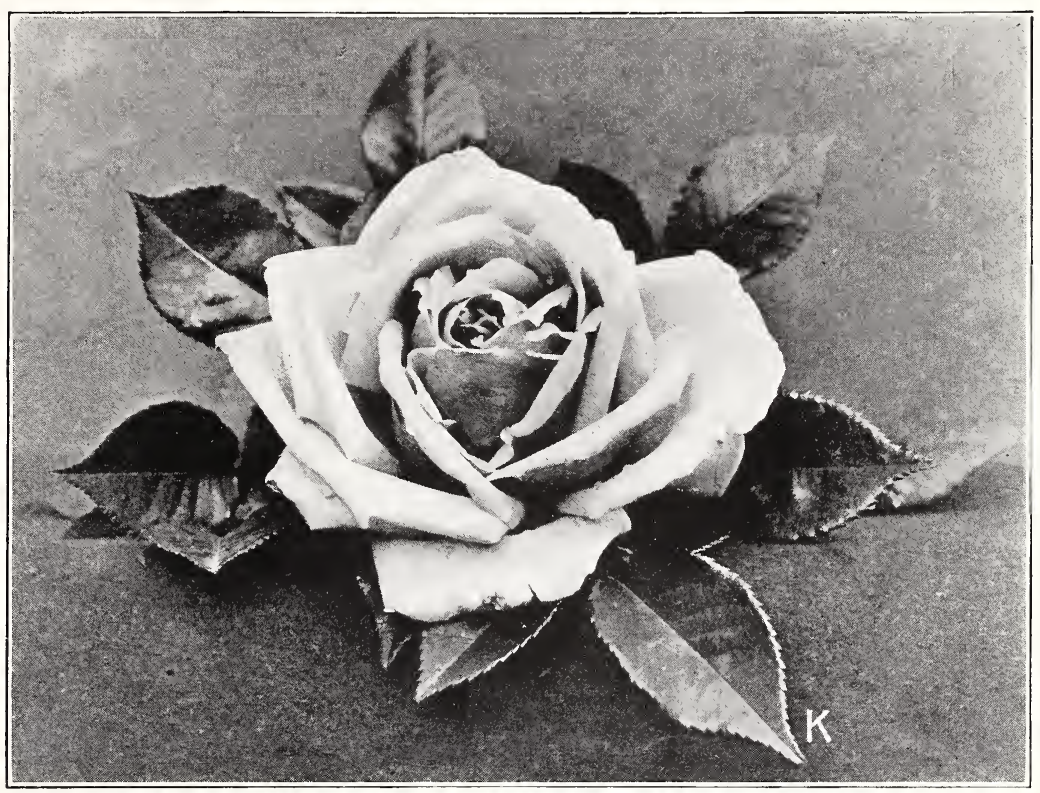

\section{ROSES}

\section{Choice Varieties for the Rose Garden}

There is nothing so desirable in a garden as a collection of fine roses, and there is no plant sells so readily, hence in ordering please name a second choice if you have one as we do not give our complete list here, due to lack of space.

We can supply some very nice tree roses in two colors at $\$ 3.00$ each.

Angelus. A new white rose, very free bloomer and beautiful buds. Each, 75c.

Golden Ophelia. A golden yellow, unsurpassed in garden roses. Each, $75 \mathrm{c}$.

Louise Catherine Breslau. Peculiar shade of salmon buff over yellow; unusual. Each, $75 \mathrm{c}$.

Los Angeles. Long stems, beautiful buds, combination of pink and amber over yellow. Each, $75 \mathrm{c}$.

Lolita Armour. Brilliant combination of corral-red and copper-red, over an orange flame color. Each, 75c.

General McArthur. Dark red, splendid shape, and color, almost ever-blooming. Each, 60c.

Hadley. Rich velvety crimson, beautiful buds. Each, 60c.

Marechel Neil. The most famous and best known rose in California. The flowers are a wonderful shade of deep yellow. Each, 75c.

\section{GENERAL COLLECTION Each, 60c}

American Beauty-Red.

Constance-Yellow.
Lady Hillingdon-Yellow.

Maman Cochet-Pink.

Columbia-Pink.

Ophelia_-Salmon.

Ulrich Brunner-Crimson.

Hoosier Beauty-Red.

Cecil Brunner-Pink Baby Rose.

Radiance-Dark Pink.

White Maman Cochet-White.

Molly Sharman-Crawford-White.

\section{Climbing Roses}

Belle of Portugal. New, strong, vigorous buds of beautiful dawn pink. Each, $75 \mathrm{c}$.

General McArthur. As good as the bush; dark red. Each, 50c.

Cecil Brunner. One of the best of all climbing baby roses; salmon pink blossoms. Each, 50c.

Dorothy Perkins. Rambler type; flowers very double bright pink. Each, $50 \mathrm{c}$.

Cherokee. White, pink and red; single blossonis. Each, 50c.

Climbing Kaiserin. Lovely white blossoms; perfect form. Each, $50 \mathrm{c}$. 


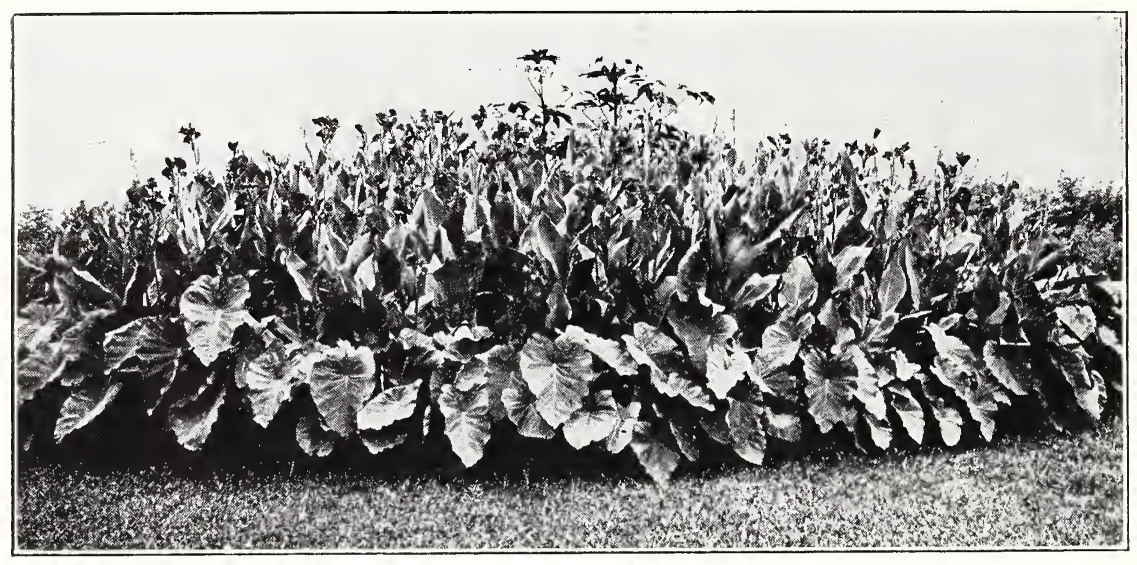

CANNA AND CALADIUM

\section{BULBOUS AND TUBEROUS-ROOTED PLANTS}

\section{When and How to Plant Bulbs}

Certain kinds of Bulbs cannot be dug before December. Such will be sent when ready. Some are dug in August-can be shipped and planted any time.

Holland grows the best Tulip Bulbs-California grows the best Gladioli Bulbs. Six of any variety at dozen rate, 50 at $100 ; 250$ at 1,000 rate.

Get your friends to club with you in ordering. We will put in extra bulbs to repay you handsomely.

We have varieties at a low price which are more valuable than many high priced sorts. Therefore, where unacquainted, we would advise your leaving selection with us.

If you leave the selection to us, giving your preference as to colors desired, we will try to please you. You will not be sent cheap or inferior stock, as all orders will be filled only from varieties listed in this catalogue, and they are the "blue-bloods" of the species.

We shall be glad to make up special assortments of bulbs for our customers who may ask our aid in deciding what to plant. Send us the anount of money you desire to invest in bulbs, state your preference of colors, and we will make up the best assortment possible.

Most failures with Bulbs are due to too shallow planting-plant Canna, Dahlia, Tuberose, lris, Shooting Star, Chuface and Calla Lily so the tops of Bulb is 3 inches below ground level. All other Bulbs 4 inches. Keep the ground loose and moist at all times.

Should you prefer Flower or Vegetable Seeds as premiums with your Bulb orders, we will send same instead of extra bulbs viz., on all $\$ 5.00$ orders we will give you $\$ 1.00$ worth of seeds; on $\$ 10$ orders $\$ 2.50$ worth of either vegetable or flower seeds. Mention sorts preferred and we will send good kinds of varieties ordered.

Specialties. Gladiolus and Dahlias are specialties with us. We have one of the finest collections in the $\mathrm{W}^{\prime}$ est. We consider these unsurpassed for beauty and continuous flowering. All our bulbs of every sort listed are of good flowering size, varying according to variety.

Size of Tubers. Some varieties produce small tubers while others produce large ones. Because they are small, do not consider them worthless. The size of the tuber does not indicate the size of plant or flower.

Write for quantity price or prices on small sizes for planting stock. We have over seventy acres devoted to nursery business.

TERMS--On orders of less than $\$ 2.00$ include 15 cents to cover postage. Cash with order. Orders sent C. O. D. will be filled provided one-third of the amount is sent with the order. At our prices we cannot afford to do a credit business.

On orders of $\$ 5.00$ or over at the dozen rate we give $\$ 1.00$ worth of extra bulbs; orders of $\$ 10.00$ or over at the dozen rate we give $\$ 2.50$ worth of extra bulbs. Larger orders in proportion. On orders of $\$ 2.00$ or over we pay postage; this applies to bulbs of every sort.

All orders shipped at the proper planting time unless otherwise requested.

OUR MOTTO: The men who work on the policy that the BEST is none too good for the customers they serve, will eventually find themselves richer by the respect, regard and confidence of those customers. Quality is the high road to a customer's good will. Prompt. ness and accuracy are impcrtant avenues to the same goal. 


\section{Gladioli-The Flower De Luxe}

Gladioli deserve their unrivaled popularity. Plant from January to August for a succession of blooms. In cutting the flower stems, allow the leaves to remain. When dried this top growth should be cut off and the bulbs stored. The bulbs should be planted about 3 inches deep in any good garden soil, preferring an open sunny situation. Plant 1 inch apart in the row. Six at the dozen rate in all sorts.

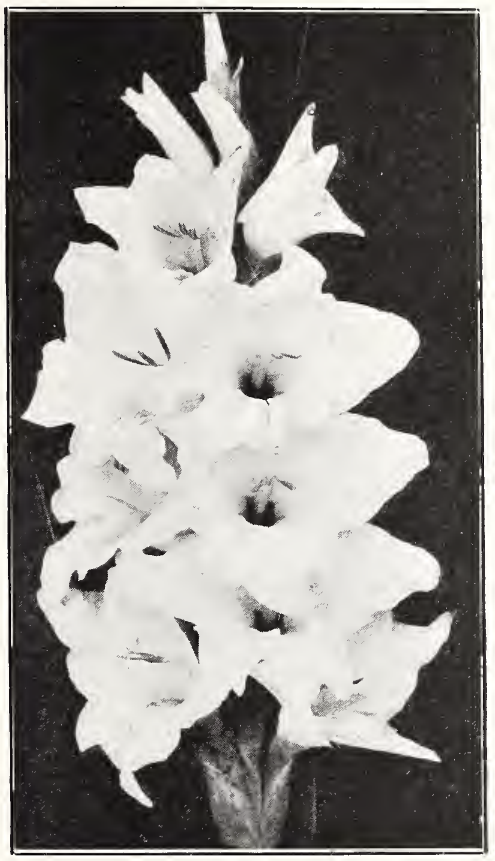

GLADIOLI

\section{YELLOW GLADS}

Autumn Queen-Cream yellow............. \$2.00 Autumn Queen-Cream yellow..............\$2 $\$ 2.00$ Golden King-Lemon yellow.................... .50

Golden Measure-Golden yellow............ 1.50

Klondike-Light yellow with maroon.... .50

Mrs. Dr. Norton-Cream and pink....... 1.50

Mary Pickford-Soft cream lemon........ 1.00

Niagara-Crocus yellow ...................... 1.00

Schwaben-Fure yellow with red......... 1.00

Yellow Hammer-Yellow with red markings

Butterfly-Large salmon yellow 1.50

\section{PINK GLADS}

Prince of Wales--Salmon Pink, fine......\$1.00 Thos. J. Kent-Shell pink-crimson streak

Myrtle-Delicate rose pink $\quad 2.50$

America-Delicate lavender pink............ $\quad .60$

Evelyn Kirkland-Coral pink................. 1.00
Doz.

General Joffre-Bright pink reddish...... $\quad .60$ Halley-Bright salmon pink.................. 1.00 Independence - Coral pink........................ $\quad .60$

Jewell-Light salmon pink-....... 3.50

Kinnemerland-Deep pink yellow throat 1.50 Marshal Foch-Light pink, large flower 1.00 Mrs. Frank Pendleton-Deep rose pink .80

Los Angeles-Shrimp pink Panama-Large deep pink ...................... 1.00 Wilbrink--Lavender pink -........................ 1.00

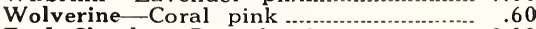

E. J. Shaylor-Deep bright rose........... 2.00 Mrs. Watt-American beauty rose........ .50 Pink Wonder - White edged with pink.. 2.00 Mrs. F. C. Peters-Rose lilac...... 4.00

Crinkle-Deep peach blossom pink....... 5.00

\section{LAVENDER GLADS}

Byron L. Smith-Orchid shaded to purple .......\$2.00

Anna Eberius-Dark velvety purple-...- 1.50

Herada-Mauve shaded to purple.......... 1.00

Louise-Lavender, bluish tinge................ 1.50

Purple Glory-Dark maroon, almost black

\section{RED GLADS}

Scarlano-Vivid scarlet red...............\$1.00 Princeps-Scarlet with white throat..... 2.00

Martha Washington-Light red 1.50

Black Pansy-Rich dark red................... 2.00

Chateau Thiery-Bright cerise, large... 1.00

Faust--Dark glossy red......................... 1.00

Golden West-Bright orange red.-1.-1.00

Gretchen Zang-Soft geranium.............. 1.00

Ida Van-Deep salmon red......................... 1.00

Los Gatos-Deep rose. carmen blotch.- 1.00

Mrs. Francis King-Flame scarlet $\quad 1.00$

Princepine-Bright scarlet ..................... 1.00

Virginia-Bright red, very showy.......... 1.00

War-Deep blood red... 1.00

Nezincott-Bright scarlet black blotch

.80

Pythia-Dark rose red................................... 5.00

Robert J. Kundred-Deep vermillion__.. 10.00

\section{WHITE GLADS}

Chicago White-Pure white with lavender markings ........................... \$.60 Glory of Holland-White tinged pink. .50 Lily White-Pure snow white............... 1.00 Peace-White with wine marks............. $\quad .80$ Miss Helen Franklin-Ruffled white with wine marks 1.00 Carmen Sylvia-Snow white pencilled

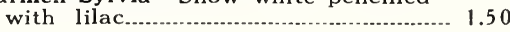

\section{BABY GLADIOLIA}

Bride-Pure white ............................ \$1.00 Blushing Bride--Deep blush pink -_..- 1.00

Ackermania - Deep red under petals...... 1.00

\section{PRIMULINUS}

Mixed Primulinus-All colors............... \$ .50 Primulinus Hybrids-Mixed colors,

mostly shades of yellow

Wagner's Mixture-25 named sorts of our best and most popular kinds and vastly superior to the ordinary mixture of others. $50 \mathrm{c}$ per dozen.

On smaller flowering size bulbs we give double the quantity at the price quoted. You get twice as many flowers for the same money.

See page 31 for special offers on all bulbs. 


\section{The Dahlia}

Formerly the rich man's plaything and the poor man's luxury, is now available to all. For the first time we are able to make a price within reach of all who admire this wonderful flower.

Seed. A good way to get a start in Dahlias, is by seed; if sown prior to May and properly cared for, three-fourths of them will bloom by Fall. It is a pleasure to watch them develop. One is apt to get specimens which would cost many dollars if purchased alone and surely one will get every ki.rd and color from seed. This is the way all new sorts are originated. Price per pkg., 25c; per oz., \$1.00.

We originate new sorts every year; these we list under our own numbers. We also list some of the standard named sorts of which we trow large quantities; hence we are able to offer as fine Dahlias as are obtainable at a price within reach of all.

\section{DECORATIVE DAHLIAS}

\section{Price 25c each; 6 for $\$ 1.00$}

The Decorative type of Dahlia is a large double flower, full to the center. Broad, flat petals with broad points or rounded tips. They flower freely on long stems and are a very popular type. Plant any time from January to July for best results.

Lady-Good clear yellow; well formed. Queen Ester-Crimson red; one of best. Gustave Duzon-Fine orange red. Lady-Deep cerise.

Rose Nell-Plum color; tall.

Alcatraz-Large bright red.

Minnie Burgle-Large light red; semicactus.

Flamingo-Dark crimson; cerise edge.

Rose Nell-Bright rose, rare color.

No. 1 - Fine terracotta red; profuse bloomer.

No. 6-Best tomato red; loose decorative.

No. 13-Dark cerise, light underneath.

No. 14-Large pink lavender.

No. 20-Maroon red; one of our best.

No. 25-Red and amber; large.

No. 26-Light yellow, pale amber tint.

No. 33-Deep red; very tall grower.

\section{SHOW DAHLIAS}

Show Dahlias are round and compact forming a ball in appearance; the petals are quilled giving the fiower the appearance of a large Pompon. The blossoms are usually held on long stiff stems-a very good cutting or garden show variety.

25c each; $\$ 2.00 \mathrm{doz}$.

A. D. Lavone-Clear shell pink.

Joe Fette-White; profuse bloomer.

Challenge-Scarlet red.

Nemesis-Dark red; very fine.

No. 9-Lemon yellow; good bloomer.

No. 16 - Lovely tomato red; heavy bloomer.

No. 29-Large maroon red; extra fine.

No. 32 - Very dark red, edged with pink.

No. 179-Rose pink; one of our best.

No. 180-Extra fine orange yellow.

No. 184-Yellow, salmon edge.

No. 186-Large white, shaded pink.

No. 191 -Very dark red.

No. 229-White; good flower.

\section{PEONY DAHLIAS}

This type of Dahlia has broad, long petals. The flowers are large and full, generally showing the yellow center. They are free blooming and very vigorous growers. Excellent for cutting.

25 c each; $\$ 2.00$ doz.

Shasta-White, pink tinge.

Bethoven-Shaded salmon and amber.

No. 2-Amber, red stripe on petal.

No. 11 - Bronze and red variegated.

No. 24-Golden color, rose underneath.

No. 27--Red, amber edge; good bloomer.

No. 34-Amber and pink.

No. 42-Spectrum red.

No. 109-Pink with white cast.

No. 127-Beautifully blended cerise pink

No. 143-Salmon tinted amber (awarded

$\$ 150.00$ prize at flower show).

No. 145-Yellow, red stripe variegated.

No. 149-Rose pink; a beauty; very tall.

No. 156--Ragged; cerise; a beauty.

No. 177-Fire King; flaming red; the tall est grower of any known sort $(10$ to $15 \mathrm{ft}$ tall). Fine for back ground.

No. 244-Fine large white.

No. 247-Extra fine yellow.

No. 253-Small red; prolific. Fine as a cut flower.

No. 254-Amber rose; 'very fine.

No. 258-Amber yellow.

No. 259-Salmon pink.

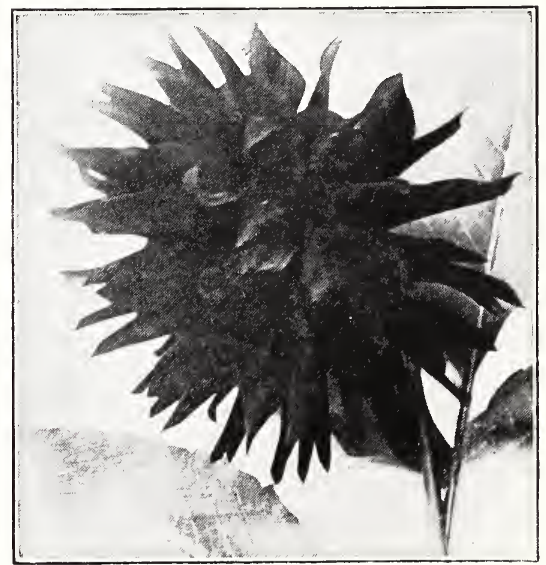

PEONY TYPE DAHLIA

\section{CACTUS AND HYBRID CACTUS DAHLIAS}

The Cactus type flowers a re double, petals long, narrow, incurved or twisted, with sharp, divided or fluted points. The stems of this type are usually strong prolific bloomers.

25c each; $\$ 2.00$ per doz.

Golden West--Very large, double, yellow. Fine cut flower.

Alcatraz-Large red.

Prezosa-Large lemon yellow.

Empire-Dark red; large.

No. 62-Yellow tinted orange buff.

No. 63-Dark cerise hybrid.

No. 72-Salmon color hybrid.

No. 90-Amber variegated; large.

No. 100-Similar to Union Jack; red and white. 


\section{POMPON DAHLIAS}

These are the babies in the Dahlia world. Pretty, compact flowers of the show type are borne on long, stiff stems holding the blossom upright and making a most wonderful display of color in garden or vase. No garden in California should be without Pompons. They are so different and so dainty. Our collection is unsurpassed. 25c each; $\$ 2.00$ per dozen

Amber Queen-A universal favorite; best of all amber sorts.

No. 179-Light old rose; large.

No. 180-Large amber shaded apricot.

No. 181-White tinged with pink.

No. 184-Beautiful yellow, salmon edge.

No. 185-Pure white similar to Joe Fetti.

No. 200-Dainty, pale yellow; fine.

No. 203-Best of all red sorts.

No. 207-Very dark red; a favorite.

\section{SINGLE OR COSMO DAHLIAS}

These are very showy and profuse bloom ers, some of flowers being 6 inches across, semi-double. We can supply these in any shade desired or mixed in all colors which makes a fine effect. State colors desired.

No. 7-Red variegated.

No. 25-Red and amber.

No. 59-Peony cerise.

No. 150-Large white tall grower.

No. 151-Large tall red single.

No. 101-A collarette; pretty border.

No. 102-A real collarette; red border.

No. 126-Variegated amber rose.

No. 127-Cerise pink.

No. 146-Red collarette; variegated.

No. 248-Large pure white.

We grow Dahlia roots by the ton, hence are able to offer some great bargains in every type and color.

See general Bulb Collections page 31 .

\section{Iris: The Goddess of the Rainbow}

Let her glorify your garden with her exquisite form and her wealth of glorious colors. No mansion too grand, no cottage too humble for a bed of Iris. Plant any time of year.

All kinds, 75c per dozen

100 , all kinds and colors mixed, our selection, $\$ 4.00$

German Iris. One of our hardiest plants, grows anywhere, and stands a lot of neglect. Very showy with a beautiful orchid flower at almost all times of year. We have a fine collection of all shades-blue, yellow, white and mixed shades, consisting of standard sorts. State colors desired and we will select accordingly.

Siberian Iris. Purple stylosis foliage, tall grass like; tlie bloom is fine for cut flowers.

Spanish Iris. lmperator, blue, one of the best cut flowers.

Calumus. Bright yellow. Thunderboldt.

\section{Cannas}

No flower makes a prettier bed or border than Cannas. They can be grown where other flowers would fail; stand lots of abuse. Special offer, 25 plants or roots, our selection, 10 sorts for $\$ 1.00$. Plant any time of the year.

Austeria. Large yellow flower, light brown markings. Per dozen, $50 \mathrm{c}$.

Burnt Orange Miniature. Pointed flowers and green foliage. Per dozen, $50 \mathrm{c}$.

Flame Red Miniature. Dense green foliage; heavy bloomer. Per dozen, $\$ 1.00$.
Hungarian. Coral pink flowers shading to light pink, bedding. Per dozen, $\$ 1.00$.

Madam Crozy. Yellow with orange mottlings; heavy blooms. Per dozen, $\$ 1.00$.

Meteor Red. Orange red flowers; red edged foliage. Per dozen, \$1.00.

Orange Bedder. Large flower with yellow mottlings. Per dozen, 60c.

Pink Miniature. Pointed pink flowers, and green foliage. Per dozen, $50 \mathrm{c}$

Queen Helen. Large yellow, lightly specked with red, often a clear red flower on the spike. Per dozen, $\$ 1.00$.

Red Bedding. Medium, brilliant red flower; dark reddish foliage. Per dozen, 50c.

Red Plume. Dense cluster of orange red; heavy bloomer. Per dozen, $\$ 1.00$.

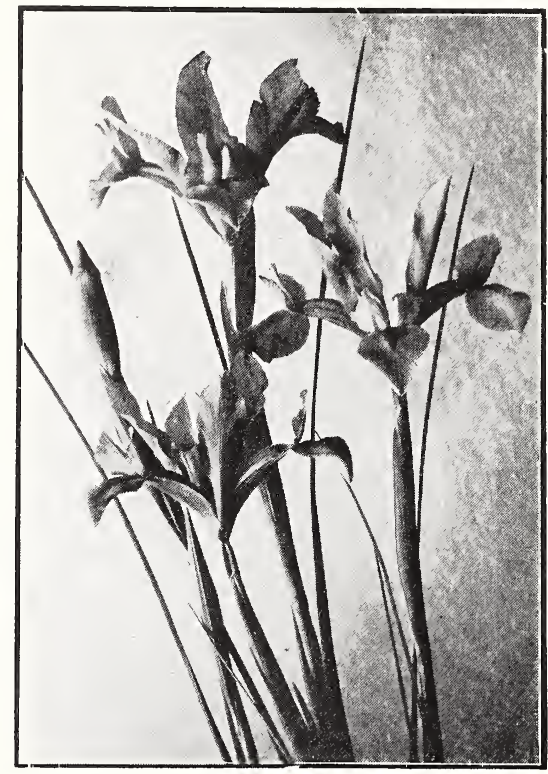

\section{SIBERIAN IRIS}

King Humbert. Giant red spikes; dark red foliage. Per dozen, $\$ 1.00$.

Spotted Gent. Large yellow flowers; red spots like a Tiger Lily. Per dozen, $\$ 1.00$.

Tom Thumb. Dwarf red; green foliage. Per dozen, $\$ 1.00$.

Jordon Giant. One of the tallest known: very broad foliage; flame red flower; good for back ground. Per dozen, $\$ 1.00$.

Wyoming Orange. Giant orange flowers; deep reddish foliage. Per dozen, $\$ 1.00$

Yellow Miniature. Clear lemon yellow; dwarf bedding canna. Per dozen, $50 \mathrm{c}$.

\section{Tuberose}

As a cut flower of beauty and lasting quality they are unsurpassed. Their waxy white flowers remain open a long time and bloom over a long period.

10c each; $\$ 1.00$ per dozen

Albino. Single, large white.

Everblooming. Single white.

Excelsion Pearl. Double white; pink bud

Mexican. Single; strongest grower.

Variegated Leaf. Silver leaved; profuse bloomer. 


\section{Chinese Lillies, Narcissus, Daffodils, Jonquils}

$10 \mathrm{c}$ each; 75c per dozen

100 assorted, our selection, $\$ 4.50$

Chinese Lily. Yellow cup.

Grand Primo. Similar to Chinese Lily, taller and larger blooms.

Paper White. Pure white.

Sir Watkins. Yellow cup with sulphur white perianth.

Empress. Yellow trumpet with pure white perianth. low.

Emperor. Perianth primrose, trumpet yel-

Grand Soliel D'Or. Yellow, orange cup.

\section{Calla Lily}

White Calla Lily. 15c each.

Yellow Calla Lily. 25c each.

\section{Rununculus}

Mixed Rununculus. 50c per dozen.

\section{Anemone}

De Caen. Poppy flowered, single mixed. $50 \mathrm{c}$ per dozen.

St. Brigid. Semi-double. 50c per dozen.

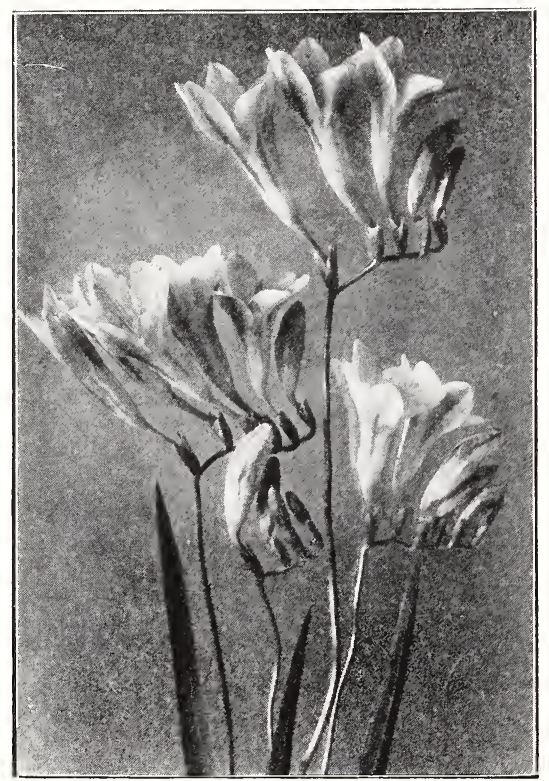

\section{PURITY FRESIA}

\section{Freesia}

Purity Freesia. Snowy white; very fragrant. 25c per dozen.

Rainbow Mixture. Mixed colors. 35c per dozen.

General Pershing. Lavender. 25c per dozen.

\section{Tritonia \\ (Or Flame Colored Fresia) \\ 50c per dozen}

\section{Sparaxis}

50c per dozen

Beautiful flowers produced on graceful spikes in striking shades; streaked, spotted, blotched; similar to Freezias.

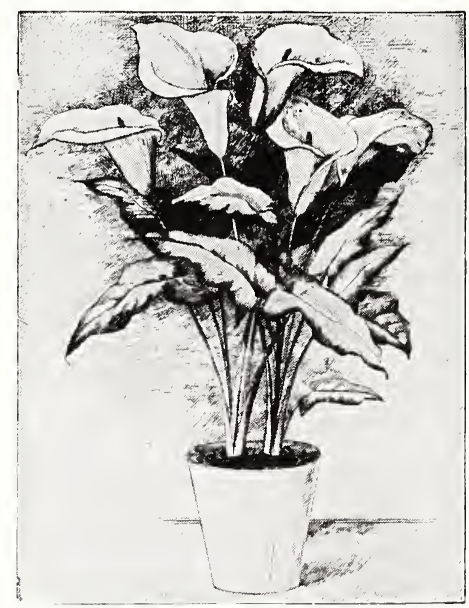

YELLOW CALLA LILY

\section{Watsonia}

We can supply in coiors of pink, orange, and white. A South African flower which thrives well in our climate. Plants three to five feet high. Spikes of large flowers similar to Gladiolus. $75 \mathrm{c}$ per dozen.

Watsonia Hybrids. All colors mixed. 50c per dozen.

\section{Star of Bethlehem}

\section{(Black Eyed Susan)} 50c per dozen

Tall stem with cluster of star flowers, pure white with dark center; a long season flower.

\section{Antholyza}

10c each; 75c per dozen

Resembles a Watsonia or Montbretia in shape, but has curved tube; extra early bloomer.

\section{Montbretia}

Orange. Orange scarlet in color. 50c per dozen.

Lemon. Deep clear yellow. 50c per dozen.

\section{Amaryllis}

\section{0c each; $\$ 1.00$ per dozen}

Belladonna Major. The beautiful rose pink early; bulbs should not be planted too deep.

Belladonna Minor. Later than Major, smaller flowers, but deeper pink. 


\section{Crinum}

Crinum (Angel Lily). Resembles Amaryllis, but taller; flowers soft pink color. $35 \mathrm{c}$ each.

\section{Agapanthus}

\section{5c each}

Very large flowers resembling Easter Lillies; almost a perpetual bloomer.

\section{Chuface}

Chuface or Ground Chestnut grows under ground like peanuts-tastes like eastern chestnut-plant them if you like chestnuts. $10 \mathrm{c}$ per package; $50 \mathrm{c}$ per pint.

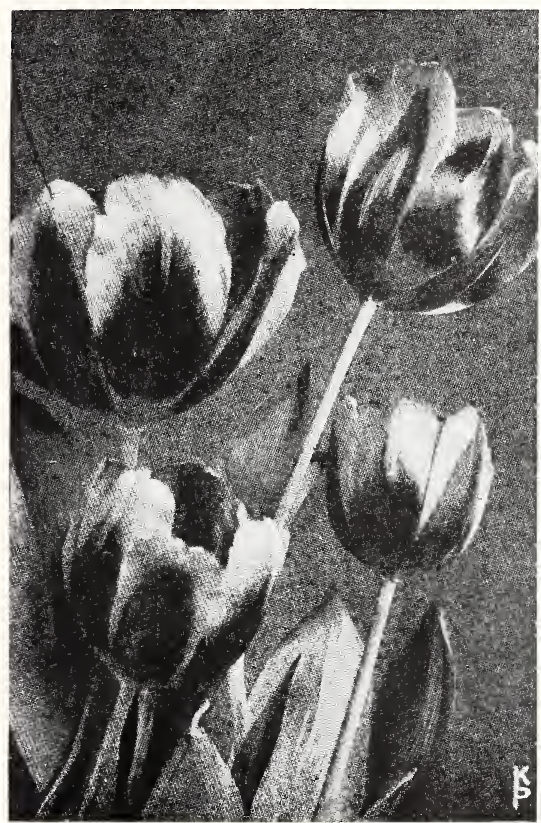

DREAM TULIP

\section{Hyacinths}

10c each; $\$ 1.00$ per dozen

City of Harlan. Bright golden yellow; large spike.

General De Witt. Light pink flower; large.

Grand Maitre. Most popular of all, blue.

Grandeur a 'Merveille. Fine rosy well formed spikes.

Gertrude Pink. Deep pink; strong compact spike; early.

Lady Dudley. Rose pink; splendid spike with large bells.

L'Innocence. Pure white; fine large bells.

La Victoire. Brilliant carmine red, forces early.

Marie Bedding. Deep purple blue; large bruad spikes.

Queen of the Blues. Beautiful clear porcelain blue.
Queen of the Pinks. Lovely bright rosy pink.

Roman Hyacinth. Mixed. All sorts and colors.

Yellow Hammer. Deep creamy yellow.

Grape Hyacinth. Small bunches of bell like flowers, intense grape blue. $25 \mathrm{c}$ per dozen; $\$ 1.50$ per hundred.

\section{Tulips}

10c each; 75c per dozen

Baronne de la Tonnaye. Bright rose, lighter margined.

Clara Butt. Soft salmon rose.

Dream. Beautiful lilac.

Feu Brilliant. Brilliant scarlet with blue base.

Gretchen. Soft pink.

King of Yellows. Yellow Tulip.

La Tulipe Noire. The nearest to the Black tulip.

\section{Dahlia Collections}

No. 1-Consisting of 12 Decorative, 12 Peony, 12 Show, 12 Cactus, 12 Pompon, 12 Single or Cosmo type, 72 bulbs, all mixed colors, $\$ 6.00$; or 12 of either type for $\$ 1.35$.

No. 2 - Consisting of 100 mixed, all kinds and colors, large bulbs, $\$ 5.00$; or $100 \mathrm{mixed}$, all kinds, smaller but good blooming size, for $\$ 3.50$

No. 3 -Consisting of 12 Dahlias, no two alike, $\$ 1.25$; or 20 Dahlias, your selection, $\$ 3.00$.

No. 4-Consisting of 100 Single or Cosmo Dahlias, very showy, all colors, mixed, $\$ 4.00 ; 100$ Single or Cosmo Dahlias, your choice, all colors inixed, $\$ 4.50$.

No. 5 - Consisting of all the above collections of 516 bulbs for $\$ 25.00$. This is less than $5 \mathrm{c}$ each. Delivery can be made at any time. We will hold same until ready to plant on deposit of $\$ 5.00$ with order.

There is no better way to get a start in Dahlias than outlined above; no such opportunity has ever before been offered the Dahlia lover. The riot of color and varieties contained in above collections are sure to please any flower lover; plant them for pleasure and profit.

\section{General Bulb Collections}

No. 6-One of each of fifty select sorts of Gladiolias, giving all shades and colors, $\$ 2.00$; or 100 mixed, $\$ 3.00$.

No. 7--Twenty-five Gladiolias; one each of different varieties, and fifty Baby Gladiolias for $\$ 1.75$

No. 8-Bulb Garden Collections. Fifty kinds of bulbs, including Daffodil, GIadiolia, Freesia, Rununculus, Hyacinth, Tulip and others, $\$ 2.00 ; 100$ for $\$ 3.50$.

No. 9 -Select Gladiolia Bulblets. Many of these will blocm the first season. They are what we plant to get big bulbs next year. They are one-third to one-half inch in size. $100, \$ 1.00 ; 1000$ for $\$ 5.00$. In nearly all sorts.

No. 10-Same as above, 75 sorts mixed at same price. This is a real bargain.

No. 11-Bulblets. Standard size about one-fourth inch. These run from 4 to 6000 to a quart and will make fine bulbs for another year. 75 sorts mixed or separate sorts, at per pint, $\$ 2.00$. State colors preferred.

No. 12-20 assorted Hyacinth, \$1.50.

No. 13-20 assorted Tulip, $\$ 1.00$.

No. 14-20 assorted Narcissus, $\$ 1.00$.

No. 15-20 assorted lris, $\$ 1.00$.

No. 16-25 assorted Canna, \$1.00. 


\section{ANNUAL AND PERENNIAL FLOWERING PLANTS}

In Pots, Each, 10c; Dozen, \$1.00

In Flats, 35c per Dozen Annuals

$\begin{array}{ll}\text { Asters } & \text { Lobelia } \\ \text { Calendula } & \text { Marigold } \\ \text { Centaurea } & \text { Stocks } \\ \text { Cosmos } & \text { Zinnia }\end{array}$

Perennials

Coreopsis

Delphinium

Dianthus

Fox Glove

Gaillardia

Gerbera

Gypsophila

Pansy

Pentstemon

Salvia

Shasta Daisy

\section{Ferns}

Adiantum (Maidenhair). Needs shady location, damp cool air, good drainage; does well in rocky places well protected from winds; needs some watering.

Nephrolepis-exaltata (Sword Fern). Best for bedding; does very well in sunny places.

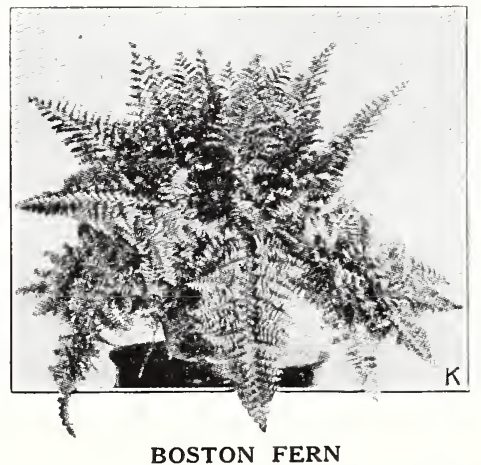

Boston Fern. Largest and most drooping plants; fine for hanging baskets; fast growing and very hardy.

Woodwardia. Tallest grower, most hardy and reliable fern; stands poor soil and drought remarkably well.

\section{Grow Your Own Plants}

Tomatoes, peppers, egg plant, in fact all vegetable and flowering plants may be grown very easily in small boxes or beds, transplanting directly from these will be found more satisfactory than to have the plants delivered or sent by mail. You are assured of better vegetables and better flowers. In planting, a light covering of well decayed barnyard fertilizer or leaf mould should be used. The seed should not be covered to a greater depth than twice or three times the diameter of the seed itself. Placing a burlap bag on top of seed or box, laying it flat on the surface and watering through it will assist in holding mois- ture and better germination will result. The burlap should be removed when the seed begins to germinate and the soil kept thoroughly moist at all times.

\section{Selected List of Flower Seeds 10c Per Packet}

\section{Annuals}

Asters. American branching; variety of colors; 1 $1 / 2$ feet high; full flowers.

California Poppy. Orange; native California flower; 1 foot high.

Calliopsis. Combination of brown and yellow, daisy like flower; 2 feet high.

Centaurea. Blue; common corn flower; 2 feet high.

Centaurea Imperialis. All colors; 2 feet high.

Chrysanthemum. Painted daisy, white, yellow, crimson; 2 feet.

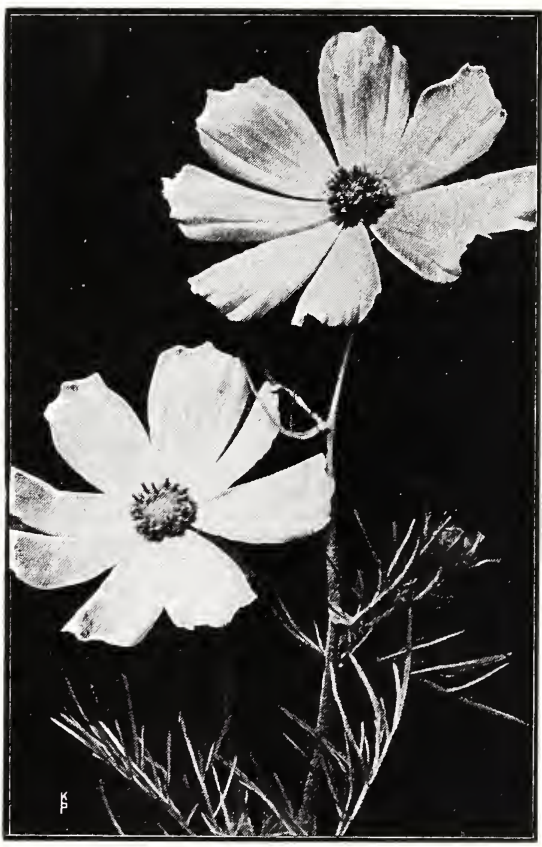

\section{COSMOS, SINGLE}

Cosmos. Crimson, rose, white and mixed; large flowering.

Gypsophila. Pure white; small flower: used for mixing with other flowers. Height, 11 , feet.

Helichrysum, Straw-flower. Mixed colors. Larkspur. Pink, blue, white; 2 feet high. 


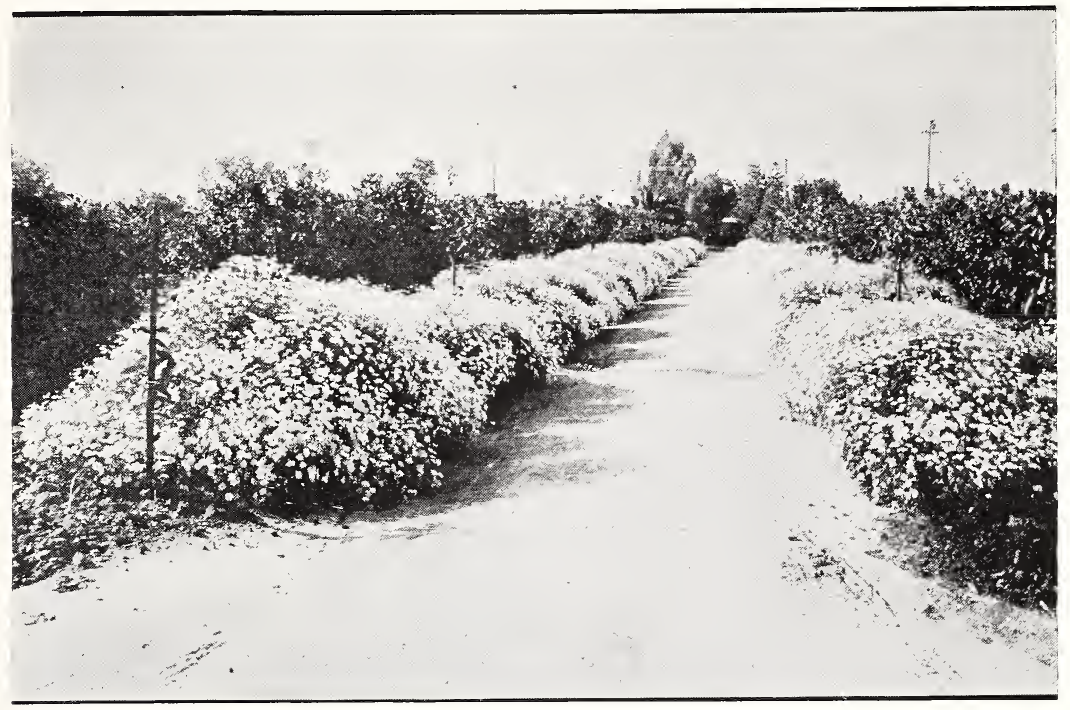

Marigold. (African Orange Ball.) Perfect ball of rich golden orange.

French Dwarf. Dark brown; 1-2 feet high. Mignonette. Yellow, red and white; fragrant; 1-2 feet high.

Nasturtium. Tall and dwarf. Golden bronze, yellow and crimson; dwarf, I foot; tall, 6 feet.

Nicotiana. Tobacco.

Scabiosa. Large flowers; assorted colors.

Sweet Peas. Spencer Giant; all colors; climbing. Per Packet, $15 \mathrm{c}$.

Stocks. Mixed colors; double and single flowers; 2 feet high.

Summer Cyprus, Mexican Fire Bush. Carmen hued. feet.

Zinnia. Mixed colors; hardy; height, 3

\section{Perennials 10c Per Packet}

Agathea. Small blue Margueritta flowers.

Antirrhinum. Old fashioned snapdragon, flowering the first year from seed; variety of colors. Height, 1-3 feet.

Calendula. Assorted colors.

Campanula. Bell flowers, Canterbury bells, blue, rose and white.

Cannas. Assorted colors.

Carnation. Single and double; red, white and pink; height, 1-2 feet.

Coreopsis. Golden yellow.

Dahlia. In assorted colors.

Delphinium. Perennial larkspur; blue; height, 3 feet.

Gaillardia. Reddish brown and yellow.

Gladiola. Fifty sorts mixed.

Hollyhock. Crimson, pink, white and yellow; height, 5 feet.

Mickalmas Daisy. Wild Aster. Varying shades of blue.
Pansies. Giant flowering and bedding; all colors.

Petunia. Single and double showy flowers; variety of colors; 1 foot high.

Phlox. Variety of colors; height, 2 feet.

Rudbeckia. Fast growing showy plant, blooming in early fall with brilliant golden yellow blooms, somewhat resembling Chrysanthemurns, beautiful for cut flowers; very hardy.

Shasta Daisy. White flower.

Statice. Purple straw flower.

Verbena. Pink, purple, and scarlet; bedding flower; height, I foot.

Viola. Purple and yellow; resembles the pansy; for bedding purposes.

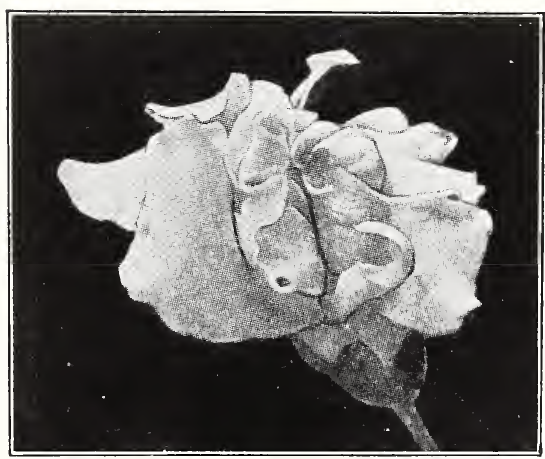

SNAPDRAGON

\section{Lawn Grass Seed}

Blue Grass, pound, $60 \mathrm{c} ; 10$ pounds, $\$ 5.50$. Clover, pound, $90 \mathrm{c} ; 10$ pounds, $\$ 8.50$. 


\section{VEGETABLE PLANTS}

\section{Asparagus}

Argenteuil. The favorite in the Paris markets, and exceedingly popular wherever grown in the United States. The stalks grow to an enormous size with tinge of purple, cooks tender, of delicious flavor. Dozen, 35c; hundred, $\$ 1.50$; thousand, $\$ 8.00$.

Palmetto. Standard among the asparagus shippers of California. This strain grows to mammoth proportions and very even in size, which makes it especially popular with shippers. The shoots are a light green, slightly tinted with pink, and are tender to an unusual length. No one will be dis. appointed with the productiveness and fine edible qualities of Palmetto Asparagus. Dozen, $35 \mathrm{c}$; hundred, $\$ 1.50$; thousand, $\$ 8.00$.

Washington. A new rust resistant variety, was bred up by the United States Bureau of Plant Industry co-operating with Massachusetts Agricultural Experiment Station, covering a period of fourteen years. This is a new and excellent variety of asparagus. Dozen, 50c; hundred, \$1.75; thousand, $\$ 12.50$.

\section{Artichoke}

French Green Globe. The standard of quality. Does not come true from seed. Resembles a rank growing thistle. The pods are cut before they bloom and are cooked and eaten like asparagus. Fine flavor and very profitable when grown for market. It is not a tuber like the Jerusalem Artichoke. $20 \mathrm{c}$ each; $\$ 2.00$ per dozen.

\section{Miscellaneous}

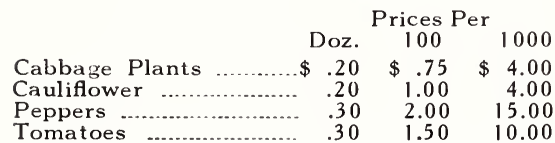

Onion Sets-Can supply Onion Sets from Ist of October to July Ist. Per lb., $25 \mathrm{c}$.

\section{Horse Radish}

Horse Radish. Maliner Krren and American. Each, 5c; hundred, \$1.25; thousand, $\$ 10.00$.

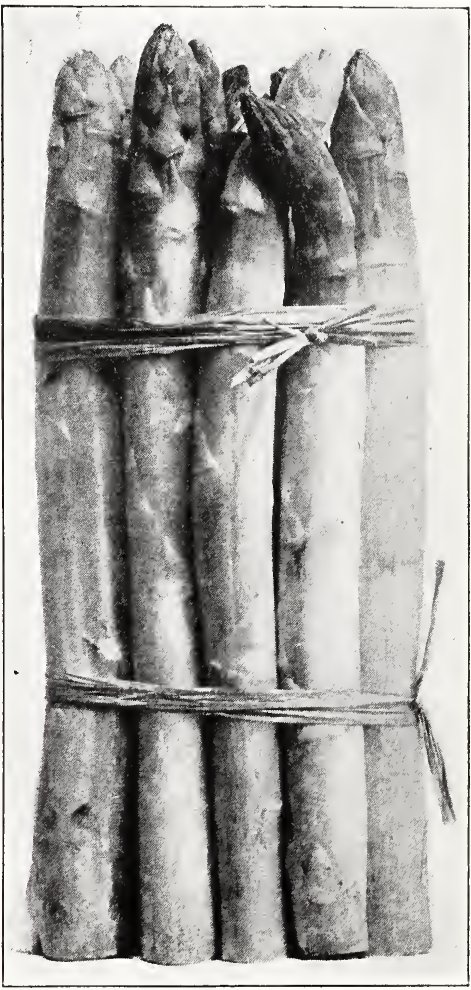

PALMETTO ASPARAGUS

\section{PLANT RHUBARB FOR PROFIT}

D LANTED commercially no vegetable yields a larger profit, nor affords more satisfactory returns when planted for family use, than Wagner's Giant Winter Rhubarb. Complete cultural directions, descriptions of varieties and prices will be found on pages 3, 4 and 5, to which attention is directed. 


\section{GARDEN AND FIELD SEEDS}

\section{Artichokes}

Large Green Globe. The favorite garden variety. Pkt., 10c; oz., 20c; 1/4 lb., \$4.00; 1 lb., $\$ 12.00$.

\section{Beans}

Fordhook Bush Lima. Vigorous grower; splendid variety. Pkt., 10c; 1/2 lb., 20c; i lb., $40 \mathrm{c}$.

Monstrous Bush Lima. Extra large in size for home or market garden. Pkt., 15c; $1 / 2$ lb., $35 \mathrm{c} ; 1$ lb., $60 \mathrm{c}$.

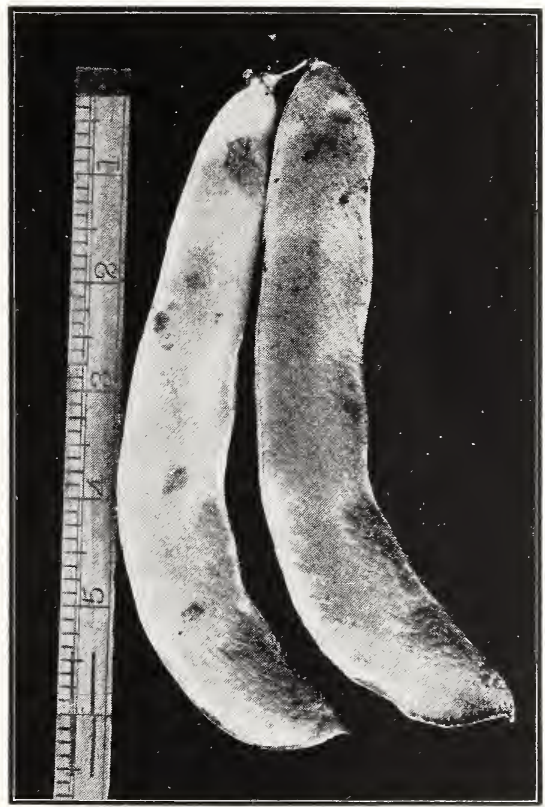

BURPEE'S BUSH LIMA

Burpees Bush Lima. Pkt., 10c; 1/2 lb., 20c; I lb., 35c.

Giant Pole Lima. The largest podded of all pole limas; vigorous grower, fine flavor. Pkt., 15c; 1/2 lb., 30c; 1 lb., 55c.

Burpees Stringless Green Pod. It is one of the greatest green pod beans to date; very tender, without strings; of the highest and best flavor. Pkt., 10c; $1 / 2$ lb., 20c; 1 lb., $40 \mathrm{c}$.

Improved Golden Wax. Strong grower; prolific; a superior bush wax bean; popular for market or garden. Pkt., 10c; 1/2 lb., $20 \mathrm{c} ; 1 \mathrm{lb}, 35 \mathrm{c}$.

Improved Prolific Black Wax. In every respect first-class; very early and continues long in bearing; immensely productive. Pkt., 10c; 1/2 lb., 20c; i lb., 35c.

Ventura Wonder Wax. A stocky bush variety bearing large, long, flat yellow pods, containing white seed with a fine flavor. Pkt., 10c; 1/2 lb., 20c; 1 lb., 35c.
White Kentucky Wonder. A very popular type of Kentucky Wonder, ls two weeks earlier than any other type of Kentucky bean. The pods average from eight to ten inches in length. Pkt., $10 \mathrm{c} ; 1 / 2$ lb., $20 \mathrm{c}$; 1 lb., 40c.

Asparagus or Yard Long. Very fine and tender; entire absence of strings; should be grown in every home garden. Pkt., 10c; $1 / 2$ lb., 75c; 1 lb., $\$ 1.50$.

Kentucky Wonder Brown. Very early and enormously productive; long been a favorite. Pkt., 10c; 1/2 lb., 20c; 1 lb., 35c.

White Creaseback. An extremely early pole bean: very prolific and an excellent shipper. Pkt., 10c; 1/2 lb., 20c; 1 lb., 35 c.

Scarlet Runner. Ornamental and useful; beans excellent quality shelled or dry. Pkt., $10 \mathrm{c} ; 1 / 2 \mathrm{lb}, 20 \mathrm{c} ; 1$ lb., $35 \mathrm{c}$.

\section{Beets}

Crosby's Egyptian. A medium sized beet, very early and small top. Smooth, deep crimson flesh; sweet and tender. Pkt., 10c; oz., 15c; $1 / 4$ lb., $35 \mathrm{c}$; 1 lb., $\$ 1.00$.

Detroit Dark Red. One of the best beets for market or home garden. Color, dark red. The root is of medium size, globular or nearly round, very smooth. Pkt., 10c; oz., 20c; $1 / 4$ lb., 45c; 1 lb., $\$ 1.25$.

Extra Early Egyptian. Very early; dark blood color; flat shape. Pkt., 10c; oz., 15c; $1 / 4$ lb., 35c; 1 lb., $\$ 1.00$.

\section{Swiss or Silver Chard}

For leaf stalks and leaves as greens. Cut often as new stalks will be produced. Pkt., $10 \mathrm{c}$; oz., 15c; $1 / 4$ lb., 35c; 1 lb., $\$ 1.00$.

\section{Brussels Sprouts}

Half Dwarf Paris Market. A half dwarf sort, bearing fine crops of round, hard sprouts of the finest quality.

\section{Cabbage}

Early Winnigstadt. Sure to head, hardy, a good shipper and very early. Pkt., 10c; oz., $35 \mathrm{c} ; 1 / 4$ lb., $\$ 1.20 ; 1$ lb., $\$ 3.50$

Early York. Solid pointed heads; standard English sorts. Pkt., 10c; oz. 35c; 1/t lb., $\$ 1.20 ; 1$ lb., $\$ 3.50$.

Cannon Ball Cabbage. This is an early round-headed type, producing a heavy crop of a solid, compact nature, and excellent quality. It is unsurpassed. It can be placed on the market as early as any other cabbage. We recommend this variety highly. Pkt., 10c; oz., 35c; 1/4 lb., \$1.65; I lb., $\$ 3.50$.

Copenhagen Market. One of the most popular round-headed cabbages with market gardeners. One of the best. The heads are round, extremely solid, and exceptionally good quality. Pkt., 10c; oz., 40c; $1 / 1 \mathrm{lb}$., $\$ 1.35$; 1 lb., $\$ 4.00$.

Early and Late Flat Dutch. Very good keeper, compact growing. Pkt., 10c; oz., $35 \mathrm{c} ; 1 / 4$ lb., $\$ 1.20 ; 1$ lb., $\$ 3.50$. 


\section{Carrots}

Improved Danver Half Long. A first-class carrot for all soils; in form midway between Long Orange and Short Horn. Of a rich, dark orange color, very smooth and handsome, 20 to 30 tons per acre is not an unusual crop. Pkt., 10c; oz., 20c; 1/4 lb., 45c; 1 lb., \$1.25.

Oxheart. A sloort carrot, especially desirable for heavy soils; especially fine for table use. Pkt., 10c; oz., 20c; 1/1 lb., 45c; 1 lb., \$1.25.

Improved Long Orange. Roots long, tapering to a point: color, deep orange. Suit able for market gardeners and for planting commercially. Pkt., 10c; oz., 20c; $1 / 4$ lb. $45 \mathrm{c}$; 1 lb., \$1.25.

Early Chantenay. The best early carrot grown for market gardeners; fine grained and sugary. Pkt., 10c; oz., 20c; 1/4 lb., $45 \mathrm{c}$; 1 lb., \$1.25.

\section{Cauliflower}

Early Snowball. A snow-white cauliflower. Leaves have a tendency to overlap at the top. In this way, it protects from injury, exposure to frost, rain or heat. Pkt., $25 \mathrm{c}$; $1 / 4$ oz., $\$ 1.00 ; 1$ oz., $\$ 3.50 ; 1 / 4$ lb., $\$ 10.00$.

Early Pearl. Should be sown from May 1 st to June 25 th. The plants are ready to be set out in from seven to ten weeks. It is large, white and very meaty; is self blanching as it is well covered and not necessary to tie up. Pkt., 10c; 1/4 oz., $\$ 1.00 ; 1$ oz., $\$ 3.50 ; 1 / 4$ lb., $\$ 10.00$.

Late Pearl Cauliflower. Attains a height of three to four feet. This is the variety that has made California Cauliflower famous. Pkt., 25c; 1/t oz., \$1.00; 1 oz., $\$ 3.50 ; 1 / 4 \mathrm{lb}$., $\$ 10.00$.

Half Early Pearl. Seed should be sown from May 25 th to July 15 th. Plants should be ready to set out in from seven to ten weeks or as soon as they have reached the proper size. Pkt., 25c; 1/4 oz., $\$ 1.00 ; 1 \mathrm{oz}$., $\$ 3.50 ; 1 / 4$ lb., $\$ 10.00$.

\section{Celery}

Golden Self-Blanching. A thrifty variety: grows 18 to 22 inches in height, stocky, heavy, solid and splendid shipper. Pkt., $15 \mathrm{c}$; oz. $80 \mathrm{c} ; 1 / 4$ lb., $\$ 2.65 ; 1$ lb., $\$ 8.00$.

Easy Blanching. Grows rather dwarf and compact; foliage light green tinged with yellow. It blanches more easily than any other variety. Pkt., 10c; oz., 40c; 1/4 lb. $\$ 1.35$; 1 lb., $\$ 4.00$.

Golden Self-Blanching. French stock; mild but characteristically flavored. Pkt. $15 \mathrm{c}$; oz., $\$ 2.00$; 1/4 lb., $\$ 6.00$; 1 lb., $\$ 20.00$.

\section{Corn}

Adams Extra Early. One of the earliest varieties. Small cob and dwarf in growth. Pkt., 10c; $1 / 2$ lb., 20c; 1 lb., 35c.

Country Gentlemen. One of the best for home use. Small white cob densely covered with splendid white grains; average eight to nine inches. Pkt., 10c; 1/2 lb., 20c; 1 lb., $35 \mathrm{c} ; 10$ lb., $\$ 3.00$.

Oregon Evergreen. One of the standard sorts for main crops everywhere. Ears large, deep grained, exceptionally tender and juicy. Pkt., 10c; $1 / 2$ lb., 20c; 1 lb., 35c; 10 lbs., $\$ 3.00$.

Wagner Evergreen. This is superior to any sort: somewhat like the Oregon Evergreen. Ears 8-10 in. long.
Black Mexican. The sweetest, richest and tenderest of all sweet corn. Turns black only when too old for table use. Pkt., 10c; $1 / 2$ lb., 20c; 1 lb., 35c; 10 lbs., $\$ 3.00$.

Golden Bantam. As a sweet corn Golden Bantam is unsurpassed. Golden Bantam is a dwarf, early variety, growing 4 to 5 feet in height; golden yellow in color. Pkt., 10c; $1 / 2$ lb., 20c; 1 lb., 35c; 10 lbs., $\$ 3.00$.

Wagner's Giant Bantam. Same as Golden Bantam except larger and more productive. Pkt., 10c; 1/ lb., 20c; I lb., 35c; 10 lbs. $\$ 3.00$.

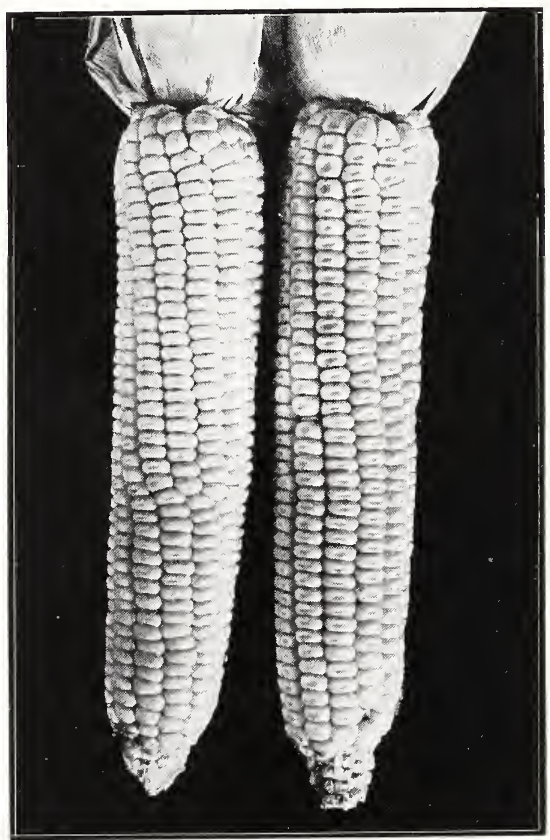

\section{WAGNER EVERGREEN}

Queens Golden Pop Corn. A large eared and handsome yellow popcorn; grains are large; pops perfectly white and very tender. 1 lb., 30c; 10 lbs., $\$ 2.50$.

White Rice. A popular and productive variety. 1 lb., $30 \mathrm{c}$; 10 lbs., $\$ 2.50$.

Hickory King. This corn is entirely distinct from all other varieties, having the largest grain with the smallest cob of any white corn. I lb., 25c; 10 lbs., $\$ 2.00$.

Champion White Pearl. Stalk short and thick. The ear grows low on stalk, from seven to twelve inches in length, size averaging sixteen rows of grain. 1 lb., 25c; 10 lbs., $\$ 2.00$

Early Mastadon. The largest yellow corn grown. Has been known to produce over 200 bushels to an acre. I lb., 25c; 10 lbs., $\$ 2.00$.

Dwarf Milo Maize. Can be grown successfully either under irrigation or by the dry farming method. This corn can be picked for one-third less per acre than the tall Milo. I lb., 25c; 10 lbs., \$2.00.

Prices on corn are subject to change without notice. If large quantities of corn are desired, send for samples and prices as all field seeds are subject to market fluctuations. 


\section{Cucumbers}

Davis Perfection. Dark, glossy green, slim and symmetrical; length, ten to twelve inches. Hold color till nearly ripe. Fine quality for table use. Pkt., 10c; oz., 20c; $1 / 4$ lb., $50 \mathrm{c}$; 1 lb., $\$ 1.75$.

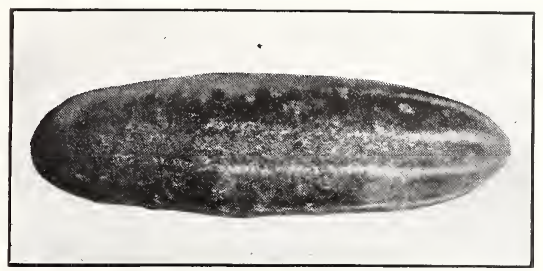

DAVIS PERFECTION

Boston Pickling. One of the best pick ling varieties; also excellent for slicing. Pkt., 10c; oz., 20c; 1/4 lb., 50c; 1 lb., $\$ 1.75$.

Early Green Cluster. Vine hardy, early and quite productive; extensively used for pickling. Pkt., 10c; oz., 20c; $1 / 4$ lb., $50 \mathrm{c}$; 1 lb., $\$ 1.75$.

Lemon. Gets its name from its shape; very early and quite popular. Pkt., 10c; oz., $25 \mathrm{c} ; 1 / 4$. lb., $75 \mathrm{c}$; 1 lb., $\$ 2.50$.

Long Green. Long and crisp. Pkt., 10c; oz., 20c; 1/4 lb., 60c; 1 lb., $\$ 2.00$.

Nichol's Medium Green. One of the best general purpose cucumbers; symmetrical, deep in color. Pkt., 10c; oz., 20c; $1 / 4$ lb., 50c; 1 lb., $\$ 1.75$.

\section{Kale}

Dwarf Curled Scotch. Very hardy variety; excellent for spring use. Pkt., 10c; oz., 20c $1 / 4$ lb., 50c; 1 lb., $\$ 1.50$.

Jersey. Of vigorous habit; grown for chicken stock only. Pkt., 10c; oz., 20c; 1/4 lb., $45 \mathrm{c} ; 1 \mathrm{lb}$., $\$ 1.25$.

Thousand Headed Kale. An excellent food for poultry; an immense yielder. Crops have yielded as high as 60 tons of green to the acre. Anyone having poultry should plant it. Pkt., 10c; oz., 20c; $1 / 4$ lb., $45 \mathrm{c}$; 1 lb., \$1.25.

\section{Lettuce}

Iceberg. A splendid head lettuce. For summer planting; compact, tender, crisp, creamy white heads. Grows a solid head in midsummer. Pkt., 10c; oz., 20c; 1/ lb., 65c; 1 lb., \$1.75.

Los Angeles Market. Forms a large, tight head of very sweet and tender leaves. Is unsurpassed in quality or yield by any of the heading varieties. Pkt., 10c; oz., $30 \mathrm{c}$; 1/4. lb., $\$ 1.00$; I lb., $\$ 3.00$.

New York. The most profitable lettuce grown. Exclusively used by hotels in Los Angeles. lt is hardy, uniform size, crisp and tender. We recommend this variety very highly. Pkt., 10c; oz., 30c; $1 / 4 \mathrm{lb}$. $\$ 1.00 ; 1$ lb., $\$ 3.00$.

Early Curled Simpson. A very popular early sort. Forms large, loose heads. Pkt. 10c; oz., 20c; 1/4 lb., 50c; 1 lb., \$1.50.

Prizehead. Large, loose-headed sort; leaves tinged with brown; very heavy, Pkt., $10 \mathrm{c}$; oz., 20c; $1 / 4$ lb., $50 \mathrm{c} ; 1$ lb., $\$ 1.50$.

Chicken Lettuce. Loose leaf sort, grown mainly for poultry and rabbits; very large leaves. Pkt., 10c; oz., 20c; 1/4 lb., 50c; lb., $\$ 1.50$.

\section{Muskmelons}

Honey Dew, Color of the skin is a light, creamy yellow, the rind being very thin. lt is a long keeping melon. We highly recommend this variety. Pkt., $10 \mathrm{c}$; oz., $25 \mathrm{c}$; $1 / 4$ lb., 8)c; 1 lb., $\$ 2.00$.

Thoroughbred Rocky Ford. An improvement over the Rocky Ford. A very fine variety. Pkt., 10c; oz., 20c; $1 / 4$ lb., 50c; 1 lb., $\$ 1.50$.

Pineapple. Large size, early, flesh green and rich flavor. Excellent shipper. Pkt. 10c; oz., 20c; 1/4 lb., 60c; 1 lb., \$1.75.

Tip Top. One of the best known varieties; salmon flesh; grown extensively in the Im perial Valley districts. Pkt., 10c; oz., 20c 1/4 lb., 50c; 1 ib., $\$ 1.50$.

Persian. One of the large varieties of Muskmelons; very thin rind and excellent flavor; color, salmon. Pkt., 10c; oz., $20 \mathrm{c}$; $1 / 4$ lb., $80 \mathrm{c}$; i lb., $\$ 2.50$.

Banana. Flesh salmon and exquisitely flavored. Brings a high price in markets. Pkt., 10c; oz., 20c; 1/4 lb., 50c; 1 lb., $\$ 1.50$

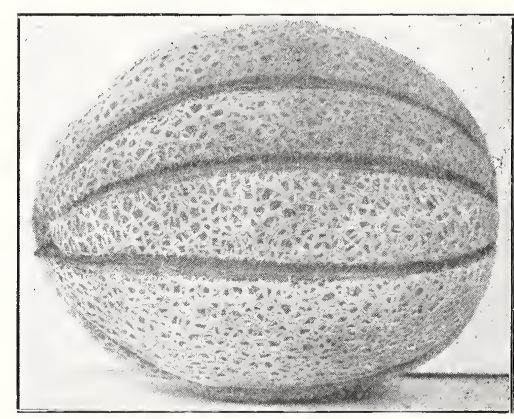

\section{ROCKY FORD MUSKMELON}

Rocky Ford Pollock. The latest improved type of the popular Rocky Ford. Perfect shipping qualities. Very good flavor. Pkt. $10 \mathrm{c}$; oz., 20c; 1/4. lb., 65c; 1 lb., $\$ 2.00$.

Golden Honey. A golden fleshed Honey Dew. The flesh is a rich golden color, very thick and sweet. Pkt., 10c; oz., 30c; $1 / 4$ lb., $\$ 1.00 ; 1$ lb., $\$ 3.00$.

\section{Casabas}

Santa Claus. The latest melon grown. Thin, hard skin with yellowish brown markings, flesh light green, good flavor. Can be picked in September or October; will keep for several months. Pkt., 10c; oz. $25 \mathrm{c}$; $1 / 4$ lb., $85 \mathrm{c}$; 1 lb., $\$ 2.50$.

This melon was introduced by J. B. Wagner from ltaly in 1902 .

Winter Pineapple. A large, late melon: corrugated skin, green flesh of pronounced pineapple flavor. Flavor is greatly improved by being stored in a cool place. Pkt., 10c; oz., $25 \mathrm{c}$; 1/4. lb., 85c; 1 lb., $\$ 2.50$.

Golden Beauty. A variety of winter pineapple which it resembies in every way except color. Pkt., 10c; oz., 25c; 1/4 lb., 85c; 1 lb., $\$ 2.50$. 


\section{Watermelons}

Klondyke. The sweetest and most prolific melon. Seed one-half as large as in other melons; good for local consumption or shipment. Pkt., 10c; oz., 25c; 1/4 lb., 85c; 1 lb., $\$ 2.50$.

Chilian. (White seeded.) Melon of merit; extra solid, crisp, sugary; a favorite because of its remarkable eating and shipping qualilies. Pkt., 10c; oz., 20c; $1 / 4$ lb., $40 \mathrm{c}$; I lb., $\$ 1.50$.

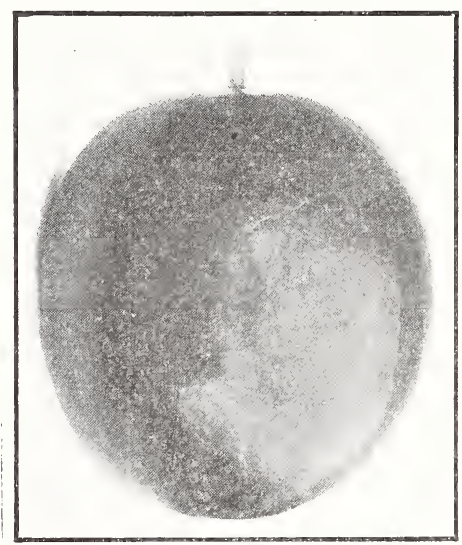

CHILIAN WATERMELON

Chilian. (Black seeded.) Possesses a rich, fruity flavor; has all the good qualities of the white seeded, a trifle sweeter, and has a very thin rind. We advise plant. ing this variety. Pkt., 10c; oz., 20c; $1 / 4$ lb., $50 \mathrm{c} ; 1$ lb., \$1.50.

Black Seeded Angeleno. A combination of the unexcelled qualities of the famous Angeleno and the favorite seeded Chilian. Pkt., 10c; oz., 20c; 1/4 lb., 65c; 1 lb., $\$ 2.00$.

Tom Watson. Exceedingly popular melon; fruit large, thin rind, good shipper; small seed area. Pkt., 10c; oz., 20c; 1/4 lb., 50c; 1 lb., $\$ 1.50$.

Yellow-Fleshed Ice Cream. Very long oblong shape; flesh a beautiful yellow; delicious flavor; different from any other variety. Pkt., 10c; oz., 20c; 1/1 lb., 50c; 1 lb., $\$ 1.25$.

\section{Okra}

Early Dwarf. Stocky growth, heavy bearer; a greenish-white color; tender, and of good flavor. Pkt., 10c; oz., 20c; 1/4 lb., $45 \mathrm{c} ; 1$ lb., $\$ 1.25$.

White Velvet. Pods round, smooth, free from seams; tender, and of good flavor. Pkt., 10c; oz., 20c; 1/1 lb., 45c; 1 lb., \$1.25.

Long Green. Later and more productive ribbed pods. Pkt., 10c; oz., 20c; $1 / 4$ lb., $45 \mathrm{c} ; 1$ lb., $\$ 1.25$.

\section{Onions}

Riverside Sweet Spanish. A most popular variety owing to its mildness in flavor; can be eaten like an apple. Good keeper; immense size. Commands a high price in any market. We unhesitatingly recommend this variety for either home or commercial growing. Pkt., 10c; oz., $\$ 1.00 ; 1 / 4$ lb., $\$ 3.35$;

1 lb., $\$ 10.00$.
Australian Brown. The flesh is pure white, close layered, juicy and tender, growing to a good size. Hardy, does especially well in the South. Pkt., 10c; oz., 20c; $1 / 4$ lb., 60c; 1 lb., \$1.75.

Bermuda Yellow Onion. More extensively grown for early market than any other. A large onion, very mild pale straw color Pkt. 10c; oz., 40c; 1/4 lb., \$1.35; 1 lb., $\$ 4.00$.

Crystal White Wax. A large white onion of the Bermuda type. Pkt., 10c; oz., 50c; $1 / 4$ lb., $\$ 1.65 ; 1$ lb., $\$ 5.00$

Southport White Globe. A great yielder; fine grained and firm. Pkt., 10c; oz., $40 \mathrm{c}$; $1 / 4$ lb., $\$ 1.35 ; 1$ lb., $\$ 4.00$.

White Portugal or Silver Skin. One of the leading white sorts, splendid variety for market garden. Pkt., $10 \mathrm{c}$; oz., $40 \mathrm{c} ; 1 / 4 \mathrm{lb}$. $\$ 1.35 ; 1$ lb., $\$ 4.00$.

Yellow Globe Danvers. A well known early onion of fine quality. Pkt., 10c; oz. $20 \mathrm{c} ; 1 / 1$ lb., 65c; I lb., $\$ 2.00$

Bunching Onion. Produces small green onions; pull while medium size before the bulb has formed. Pkt., 10c; oz., $35 \mathrm{c}$; $1 / 4$ lb., $\$ 1.20 ; 1$ lb., $\$ 3.50$.

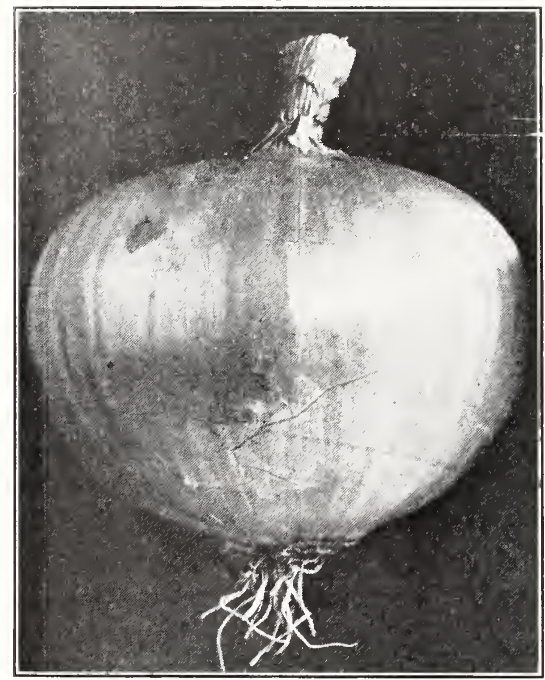

SWEET SPANISH

\section{Parsley}

Champions Moss Curled. Vigorous; compact; excellent for garnishing and flavoring leaves fine and crisp. Pkt., 10c; oz., 20c; $1 / 4$ lb., 60c; 1 lb., $\$ 1.75$.

Plain Parsley. Leaves flat, deeply cut but not curled; very dark green in color and very hardy. Pkt., $10 \mathrm{c}$; oz., 20c; $1 / 4$ lb., $50 \mathrm{c}$; 1 lb., $\$ 1 . j 0$

\section{Parsnips}

Hollow Crowned. The best all around parsnip; excellent for table or stock. A sure cropper. Pkt., 10c; oz., 20c; 1/ lb. $65 \mathrm{c} ; 1$ lb., $\$ 2.00$. 


\section{Peas}

American Wonder. Stocky, erect and very prolific. Especially good for the home garden. Pkt., 10c; 1/2 lb., 20c; 1 lb., $35 \mathrm{c}$.

Dwarf Telephone. A dwarf growing strain of the Telephone variety. Pkt., 10c; $1 / 2 \mathrm{lb}$. 20c; 1 lb., $35 \mathrm{c}$.

McLean's Little Gem. A dwarf, first early pea of unusual value and excellent flavor. Pkt., 10c; $1 / 2$ lb., 20c; 1 lb., $35 \mathrm{c}$.

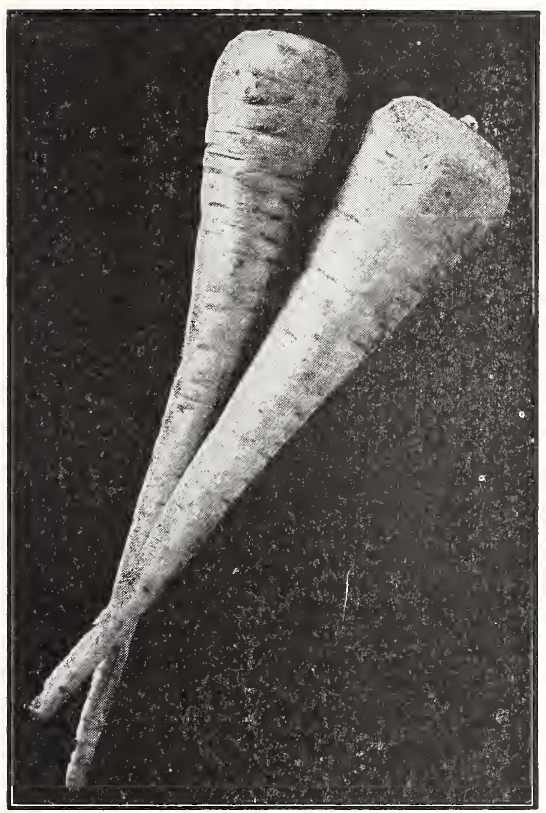

PARSNIP

Admiral or Senator. A new sort. It is a good variety, thick green foliage, bears well; large, well filled pods. Pkt., 10c; $1 / 2$ lb., $20 \mathrm{c} ; 1$ lb., $35 \mathrm{c}$.

Stratagem. Keeps well after picking. The majority of peas purchased locally are of this variety. It grows without any support. Pkt., 10c; 1/2 lb., 20c; 1 lb., $30 \mathrm{c}$.

Yorkshire Hero. Its strong vigorous growth makes this pea especially valuable to the market gardener; grows bushy; yields prodigiously. Pkt., 10c; $1 \frac{1}{2}$ lb., 20c; 1 lb., $35 \mathrm{c}$.

Alderman. Well flavored pea; vines tall and branching; bearing large deep green pods. Pkt., 10c; $1 / 2$ lb., 20c; 1 lb., $35 \mathrm{c}$.

Telephone. A fine wrinkled pea growing about four feet high; very prolific and pods large. Pḱt., 10c; 1/2 lb., 20c; 1 lb., $35 \mathrm{c}$.

\section{Peppers}

Cayenne. Pods small, coral red when ripe; very hot and strong; best kind for seasoning pickles. Pkt., 10c; oz., 80c; 1 í lb., $\$ 2.65$; 1 lb., $\$ 8.00$.

Mexican Chili. Of medium size, pear shaped; turns bluish black when dried. Pkt., $10 \mathrm{c}$; oz., $50 \mathrm{c} ; 1 / 4$ lb., $\$ 1.65 ; 1$ lb., $\$ 4.50$.
Perfection Pimento. All home gardens should include Pimento Peppers. Pkt., 10c; oz., 60c; $1 / 4$ lb., $\$ 2.00 ; 1$ lb., $\$ 6.00$.

Chinese Giant Pepper. A pepper of exceptional merit; very mild and an ideal variety for the home garden; fine texture and ideal as a stuffing pepper. Pkt., $10 \mathrm{c}$; oz., $80 \mathrm{c}$; $1 / 4$ lb., $\$ 2.50 ; 1$ lb., $\$ 8.00$.

Topepo or Yellow Pinnentum. This is a cross of pepper and tomato; highly flavored and unsurpassed for table.

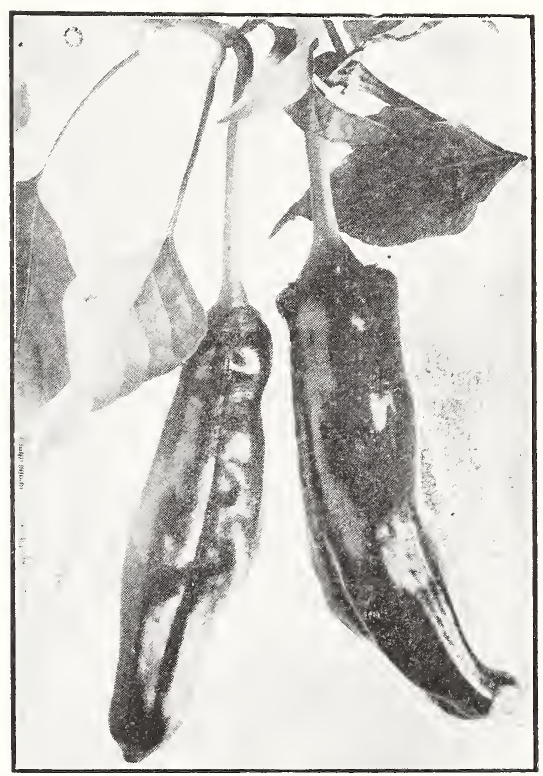

\section{PEPPERS}

\section{Pumpkins}

Kentucky Field Pumpkin. A heavy fleshed remarkably sweet pumpkin. A splendid keeper; fine sort for family use and market. Pkt., 10c; oz., 20c; 1/4 lb., 35c; 1 lb., $\$ 1.00$.

Boston Pie or Small Sugar. A very popular table variety. Pkt., 10c; oz., 20c; 1/4 lb., $50 \mathrm{c} ; 1$ lb., $\$ 1.50$.

Big Cheese. Best stock pumpkin and best keeper. Pkt., 10c; oz., 20c; 1/4 lb., 35c; i ib., $\$ 1.00$.

Mammoth Tours Pumpkin. Attains immense size. A fine stock variety; its rich flavor makes it also valuable for canning and home use. Rapid grower. Pkt., 10c; oz., 20c; 1; lb., 35c; 1 lb., \$1.00.

Sweet or Early Sugar. This is the small sweet pumpkin that has made the New England States famous for their pies. Pkt., $10 \mathrm{c}$; oz., 20c; 1/4 lb., 50c; 1 lb., $\$ 1.50$.

Connecticut Field or Jack O'Lantern. A fine variety for daily ranches adding to quality of milk and butter. Pkt., 10c; oz., $20 \mathrm{c}$; 1/ 1b., 35c; 1 lb., $\$ 1.00$.

\section{Rhubarb}

Wagner's Giant Crimson. Pkt., $10 \mathrm{c}$; oz., $\$ 1.60 ; 1 / 1$ lb., $\$ 5.00 ; 1$ lb., $\$ 16.00$.

Dodge. Pkt., 10c; 1/ lb., \$1.50; 1/2 lb. $\$ 2.50 ; 1$ lb., $\$ 4.00$. 


\section{Radishes}

California Mammoth White. A winter sort; flesh, white, firm and excellent flavor. Pkt., 10c; oz., 20c; $1 / 4$ lb., 50c; 1 lb., \$1.50.

Early Long Scarlet Short Top. Very brittle and sweet; matures in twenty-five to thirty days; adapted to the home or market garden. Pkt., 10c; oz., 20c; $1 / 4$ lb., 50c;

White Bush Scallop. This well known summer squash has been the standard for more than flity years, and always in demand because of its earliness. Delicious whether stewed or gried like egg plant. Pkt., 10c; oz., 20c; 1/4 lb., 40c; lb., \$1.25.

Zucchini or Italian. The favorite ltalian squash. lt should be eaten when quite young, 4 to 6 inches long. It is a delicious summer variety. It is more popular on the market than White Bush Scallop. Pkt., 10c; oz., $20 \mathrm{c} ; 1 / 4$ lb., $40 \mathrm{c}$.

Japanese Summer Radish. Grows as long as twenty-four inches; very tender, mild and of excellent flavor. Pkt., 10c; oz., 25c; $1 / 4$ lb., $85=; 1$ lb., $\$ 2.50$.

Scarlet Globe. Very early; a little longer than round; small top, brilliant deep scarlet. Pkt., 10c; oz., 25c; $1 / 4$ lb., 50c; 1 lb., $\$ 1.50$.

French Breakfast. An early variety with good flavor and very pretty; a favorite wherever known. Pkt. 10c; oz., 25c; 1/4 lb., 50c.

Mixed Radishes. Supply a nice assortment for table; all sizes and colors.

\section{Squash}

Long White Vegetable Marrow. An Eng. lish variety of delicious flavor. Pkt., 10c: oz., 20c; $1 / 4$ lb., 60c; 1 lb., $\$ 1.75$.

Summer Crook Neck. This is the richest summer squash, very early and productive. Pkt., 10c; oz., 20c; 1/4 lb., 50c; 1 lb., \$1.50.

Banana Squash. Firm and solid; flesh good quality. Pkt., 10c; oz., 20c; $1 / 4$ lb., $50 \mathrm{c} ; 1$ lb., $\$ 1.50$.

Fordhook. One of the best late summer varieties. Thick skin, bright yellow. Heavy meat. Pkt., 10c; oz., 20c; 1/4 lb., 60c; 1 lb., meat.

Hubbard. The best winter variety grown. Vigorous and productive; richly flavored, yellow flesh. Pkt., 10c; oz., 20c; $1 / 4$ lb., $50 \mathrm{c} ; 1$ lb., \$1.50.

\section{Spinach}

Bloomdale. Thick, dark green wrinkled leaves, very hardy. The earliest and best for autumn use. Pkt., 10c; oz., 15c; $1 / 4$ lb., $20 \mathrm{c} ; 1$ lb., 60c.

Long Standing. Leaves large, thick and crimped with a fleshy appearance. Matures quickly; very tender and fine flavored. Pkt., $10 \mathrm{c}$; oz., 15c; $1 / 4$ lb., 20c; 1 lb., 60c.

\section{Tomatoes}

Eeefsteak. This is an exceedingly popular variety. One of the best tomatoes grown. 1t is very prolific. Bright red color, firm substantial meat, luscious flavor. Pkt., 10c; oz., 70c; $1 / 4$ lb., $\$ 2.35$; 1 lb., $\$ 7.00$.

Bonny Best. Extra early, scarlet, round variety of great value. Fruit of even size. Pkt., 10c; oz., 40c; 1/t lb., $\$ 1.25 ; 1$ lb., $\$ 4.00$.

Globe. A very nearly round tomato of good quality. Early maturing. Pkt., 10c; oz., $45 \mathrm{c}$; $1 / 4$ lb., $\$ 1.50$; 1 lb., $\$ 4.50$.
Ponderosa. Very smooth and solid; very large size. Pkt., 10c; oz., 85c; $1 / 4$ lb. $\$ 2.25 ; 1$ lb., $\$ 6.50$.

San Jose Canner. Used extensively for canning purposes; good market garden tomato. Pkt., 10c; oz., 75c; 1/4 lb., $\$ 2.50$; 1 lb., $\$ 7.50$.

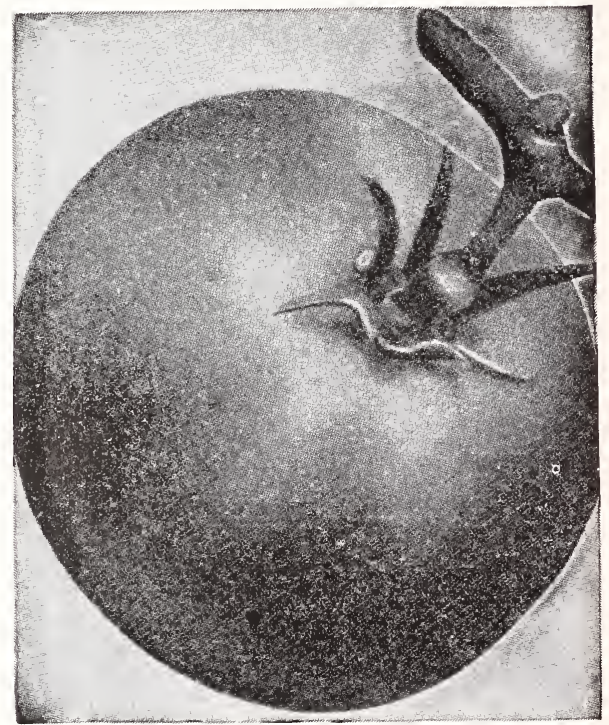

\section{EARLIANA TOMATO}

Stone. The old favorite; best for the market. Pkt., 10c; oz., 40c; 1/4 lb., \$1.35; 1 lb., $\$ 4.00$.

Spark's Earliana. Early prolific and very solid; noted as a good shipper. Pkt., 10c; oz., 40c; 1/4 lb., \$1.35; 1 lb., $\$ 4.00$.

\section{Turnips}

Extra Purple Top Milan. A week earlier than the earliest other sorts. Medium size, flat and thick, purple top, white flesh. It accommodates itself to either Spring or Fall. Pkt., 10c; oz., 20c; 1/4 lb., 40c; 1 lb., $\$ 1.25$.

Early White Egg. An egg shaped variety for Spring and Fall sowing, flesh firm, fine grained, mild and sweet. Pkt., 10c; oz., $20 \mathrm{c} ; 1 / 4$ lb., 40c; 1 lb., \$1.25.

Early Snowball. Grows even in size and is most completely described by its name; pure white and round as a ball. Crisp and mellow. Pkt., 10c; oz., 20c; 1/1 lb., 40c; 1 lb., \$1.25.

Red Top White Globe. A large rapid growing sort, flesh pure white and best flavor of any turnip; skin white with red top. Pkt., 10c; oz., 20c; 1/4 lb., 40c; 1 lb., $\$ 1.25$.

Purple Top Strap Leaf. Very productive; matures quickly; flesh white and sweet. Pkt., 10c; oz., 20c; 1/4 lb., 40c; 1 lb., \$1.25.

Improved Yellow Purple Top Rutabagas. Standard sort both for stock feeding and table use. Flesh yellow, solid and sweet. Pkt., 10c; oz., 20c; $1 / 4$ lb., $45 \mathrm{c} ; 1$ lb., $\$ 1.25$. 


\section{.}
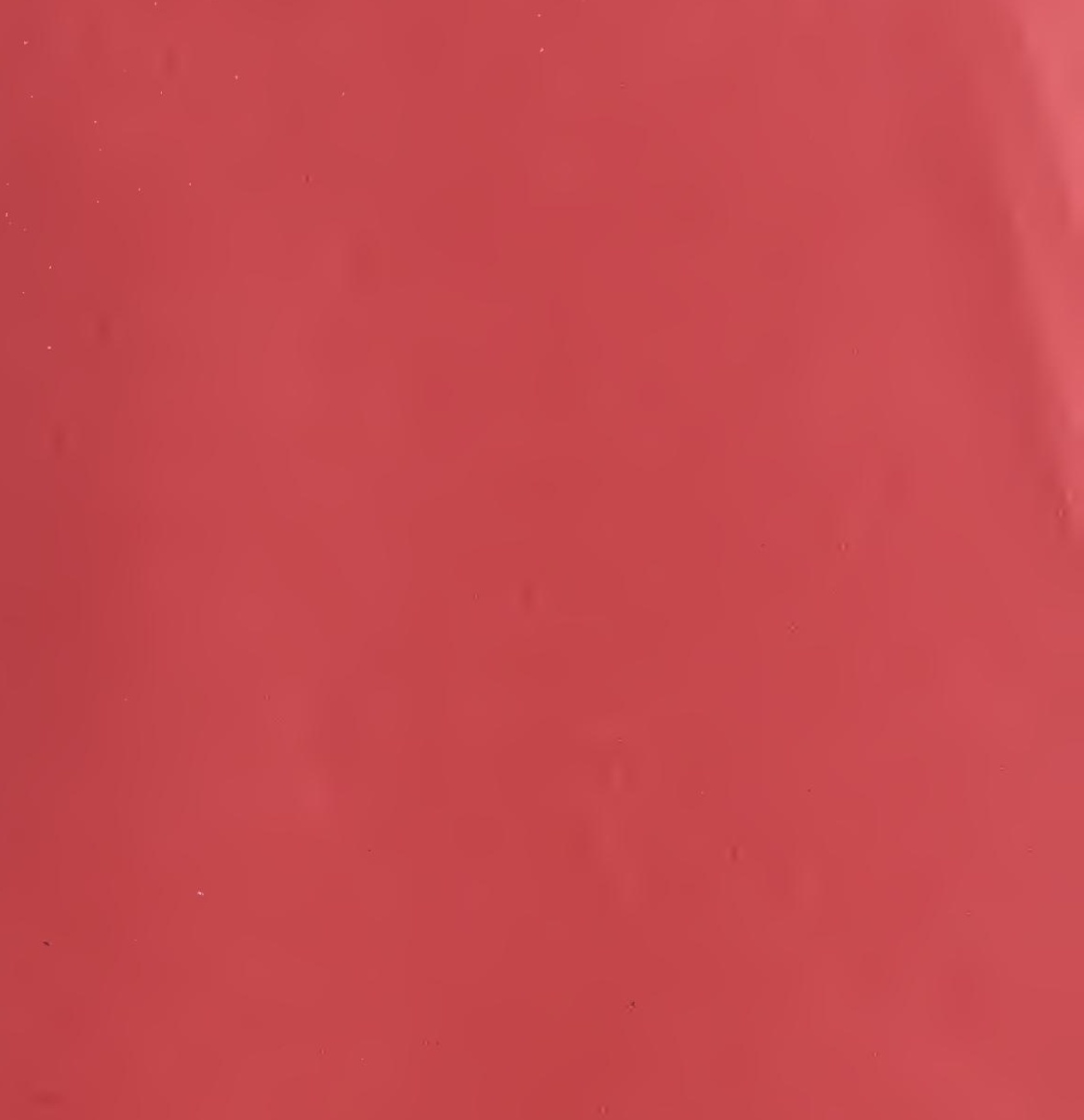

n

$$
\begin{aligned}
& +4 \\
& =8-1
\end{aligned}
$$

$=$ 


\section{WAGNER NURSERIES}

1350 North Foothil. BOULEVARd

PASADENA, CALIFORNIA 